\title{
GEOLOGIC MAPS OF THE EASTERN ALASKA RANGE, ALASKA, (44 QUADRANGLES, 1:63,360 SCALE) DESCRIPTIONS AND INTERPRETATIONS OF MAP UNITS
}

by

Warren J. Nokleberg, John N. Aleinikoff, Gerard C. Bond, Oscar J. Ferrians, Jr.,

Paige L. Herzon, Ian M. Lange, Ronny T. Miyaoka, Donald H. Richter, Carl E. Schwab, Steven R. Silva, Thomas E. Smith, and Richard E. Zehner

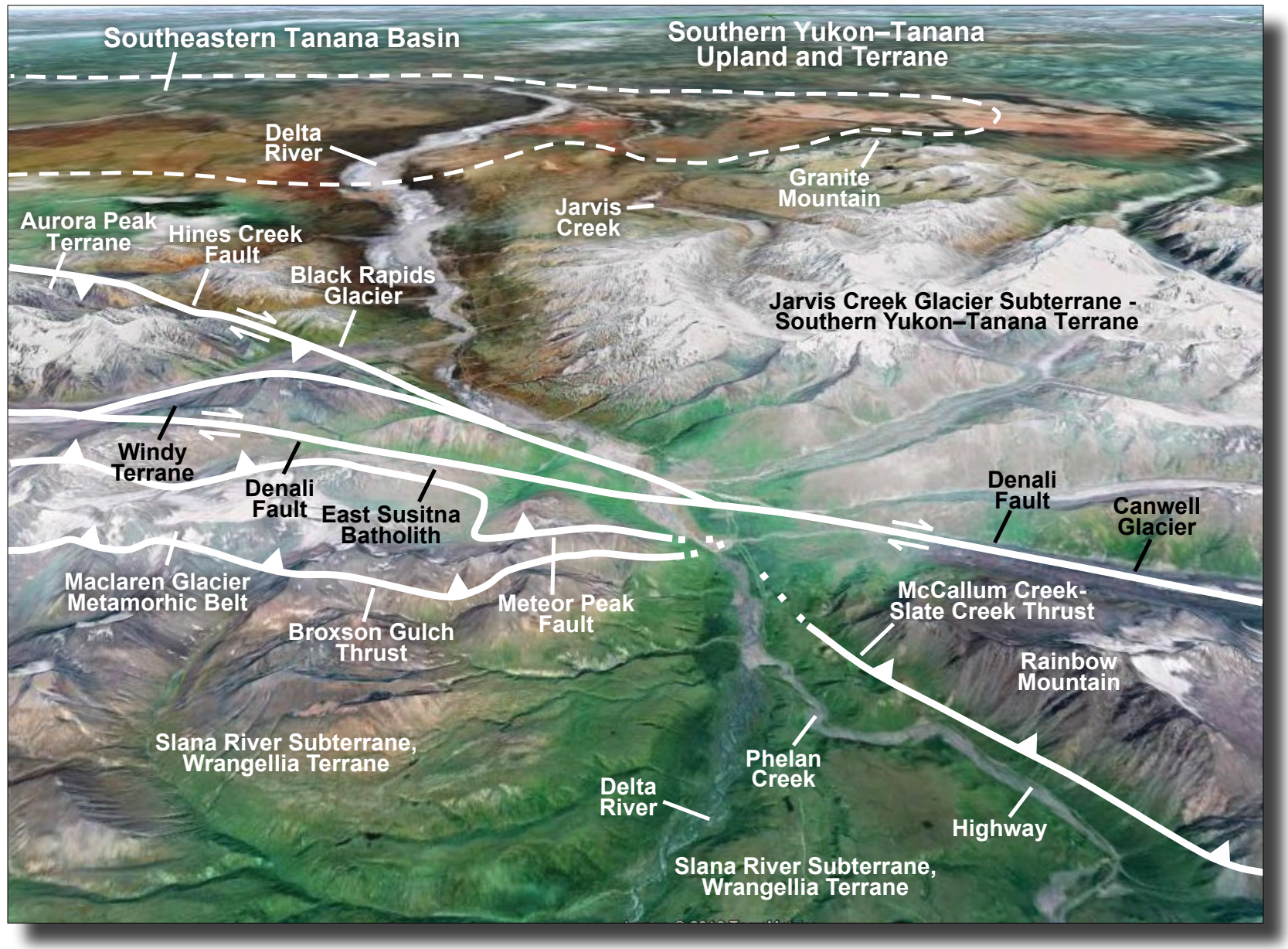

Published by

STATE OF ALASKA

DEPARTMENT OF NATURAL RESOURCES

DIVISION OF GEOLOGICAL \& GEOPHYSICAL SURVEYS 



\title{
GEOLOGIC MAPS OF THE EASTERN ALASKA RANGE, ALASKA, (44 QUADRANGLES, 1:63,360 SCALE) DESCRIPTIONS AND INTERPRETATIONS OF MAP UNITS
}

\author{
Warren J. Nokleberg, John N. Aleinikoff, Gerard C. Bond, Oscar J. Ferrians, Jr., \\ Paige L. Herzon, lan M. Lange, Ronny T. Miyaoka, Donald H. Richter, Carl E. Schwab, \\ Steven R. Silva, Thomas E. Smith, and Richard E. Zehner
}

COVER: View toward the north across the eastern Alaska Range and into the southern Yukon-Tanana Upland highlighting geologic, structural, and geomorphic features. View is across the central Mount Hayes Quadrangle and is centered on the Delta River, Richardson Highway, and Trans-Alaska Pipeline System (TAPS).

Major geologic features, from south to north, are: (1) the Slana River Subterrane, Wrangellia Terrane; (2) the Maclaren Terrane containing the Maclaren Glacier Metamorphic Belt to the south and the East Susitna Batholith to the north; (3) the Windy Terrane; (4) the Aurora Peak Terrane; and (5) the Jarvis Creek Glacier Subterrane of the Yukon-Tanana Terrane.

Major structural features, from south to north, are: (1) the young (late Pleistocene) McCallum-Slate Creek Thrust along which Tertiary sedimentary rocks are being thrust under the Wrangellia Terrane; (2) the Late Cretaceous Broxson Gulch Thrust along which the Wrangellia Terrane is thrust under the Maclaren Terrane; (3) the Late Cretaceous Meteor Peak Fault along which the Maclaren Glacier Metamorphic Belt is thrust under the East Susitna Batholith; (4) the active Denali Fault that separates the Maclaren and Wrangellia Terranes to the south from the Windy, Aurora Peak, and Yukon-Tanana Terranes to the north; and (5) the late Pleistocene Hines Creek Fault that separates the Aurora Peak Terrane to the south from the Yukon-Tanana Terrane to the north and along which the Yukon-Tanana Terrane is being thrust over Pleistocene glacial moraines.

Major geomorphic features, from south to north, are: (1) the east-west-trending Eastern Alaska Range; (2) Rainbow Mountain along the southern margin of the Alaska Range; (3) Canwell and Black Rapids Glaciers that occur mainly along the Denali Fault, which cuts through the center of the Eastern Alaska Range; (4) the southeastern part of the Tanana Basin; and (5) the Southern Yukon-Tanana Upland; and (5) the Delta River that flows northward across the Alaska Range.

\section{Report of Investigations 2015-6}

\author{
State of Alaska \\ Department of Natural Resources \\ Division of Geological \& Geophysical Surveys
}




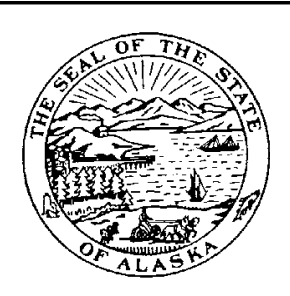

\section{STATE OF ALASKA}

Bill Walker, Governor

\section{DEPARTMENT OF NATURAL RESOURCES}

Mark Myers, Ph.D., Commissioner

\section{DIVISION OF GEOLOGICAL \& GEOPHYSICAL SURVEYS}

Steve Masterman, State Geologist and Director

Publications produced by the Division of Geological \& Geophysical Surveys (DGGS) are available for free download from the DGGS website (www.dggs.alaska.gov). Publications on hard-copy or digital media can be examined or purchased in the Fairbanks office:

\section{Alaska Division of Geological \& Geophysical Surveys 3354 College Rd., Fairbanks, Alaska 99709-3707 \\ Phone: (907) 451-5020 Fax (907) 451-5050 \\ dggspubs@alaska.gov \\ www.dggs.alaska.gov}

Alaska State Library

State Office Building, 8th Floor 333 Willoughby Avenue

Juneau, Alaska 99811-0571

Elmer E. Rasmuson Library University of Alaska Fairbanks Fairbanks, Alaska 99775-1005
Alaska Resource Library \& Information Services (ARLIS)

3150 C Street, Suite 100

Anchorage, Alaska 99503-3982

University of Alaska Anchorage Library

3211 Providence Drive

Anchorage, Alaska 99508-4614 


\section{CONTENTS}

INTRODUCTION ...................................................................................................... 1

General information and topographic setting of the eastern Alaska Range.............................................................. 1

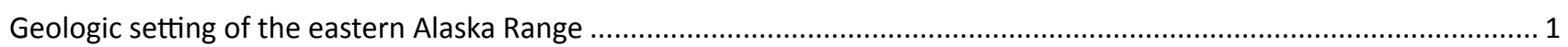

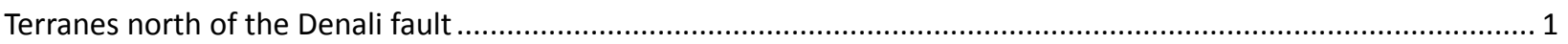

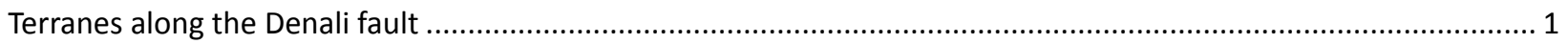

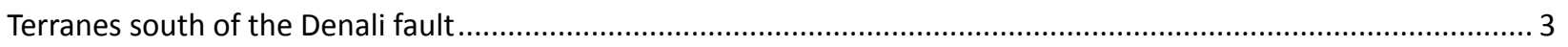

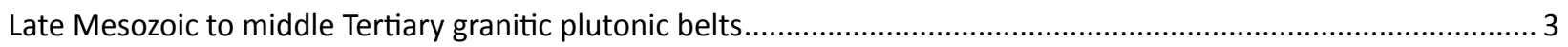

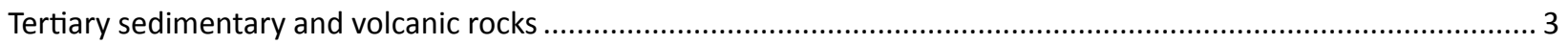

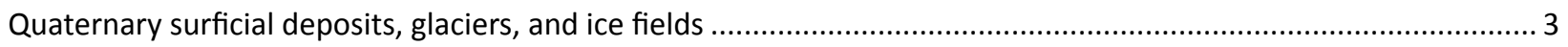

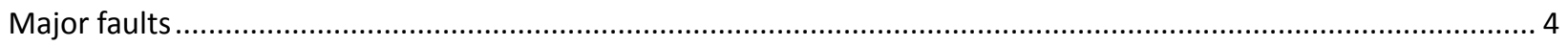

Tectonic summary

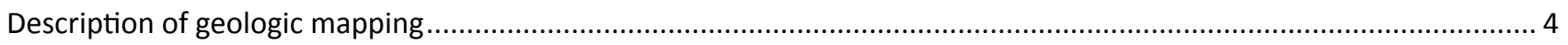

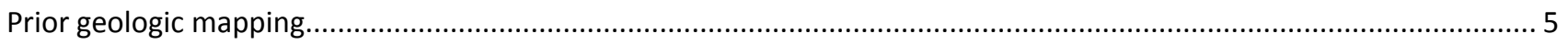

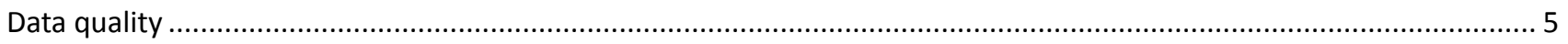

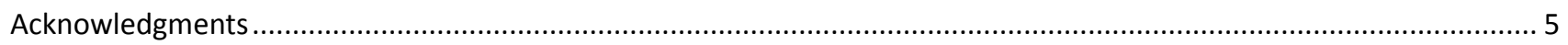

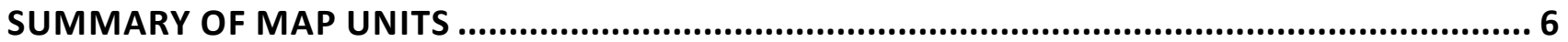



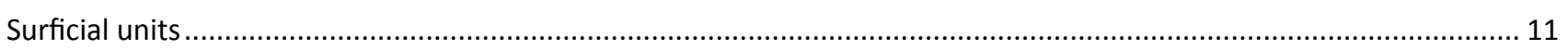

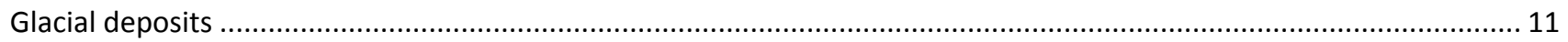

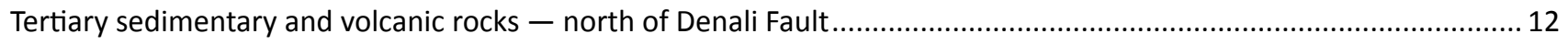

Post-accretionary alkalic mafic and associated plutonic rocks - north of Denali Fault.............................................. 13

Post-accretionary granitic plutonic rocks — north of Denali Fault ....................................................................... 14

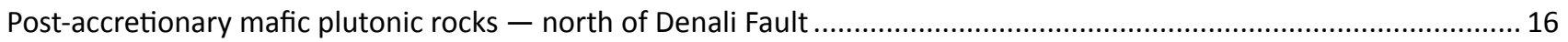



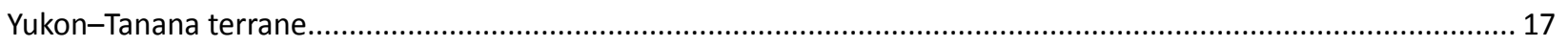

Macomb subterrane - South of Tanana River fault and north of Elting Creek fault........................................ 18

Jarvis Creek Glacier subterrane - South of Elting Creek fault and north of Hines Creek and Mount

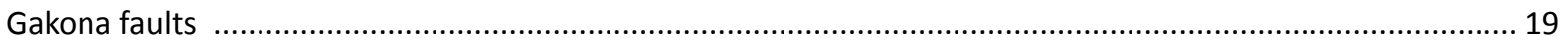

Pingston terrane - South of Hines Creek fault and north of Nenana Glacier and Denali faults ............................. 23

Aurora Peak terrane - South of Nenana Glacier fault and north of Denali fault .................................................... 25

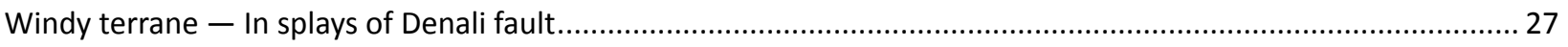

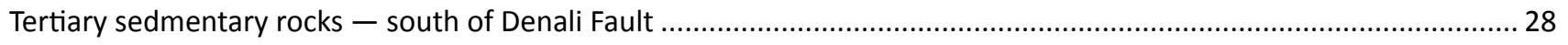

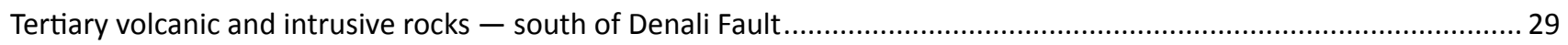

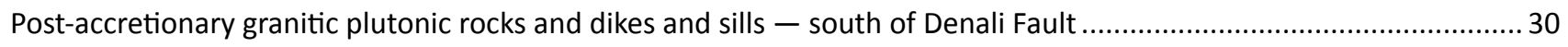

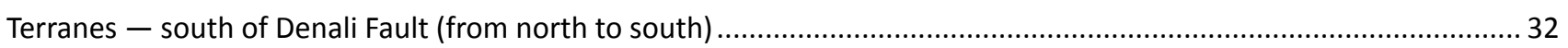

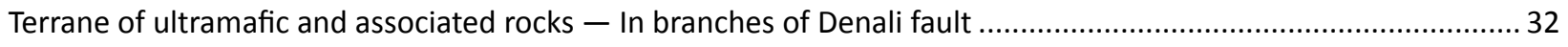

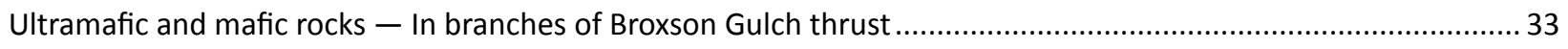

Maclaren terrane - South of Denali fault and north of Broxson Gulch thrust...................................................... 34

East Susitna batholith, and schist, quartzite, and amphibolite - South of Denali fault and north of

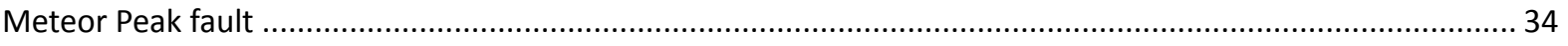

Maclaren Glacier metamorphic belt - South of Meteor Peak fault and north of Broxson Gulch thrust............ 36

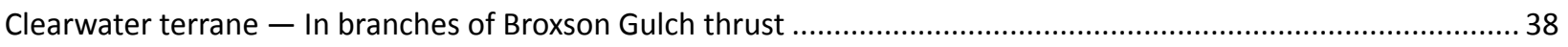

Wrangellia terrane - South of Broxson Gulch thrust and Denali fault...................................................................... 39

Fault-bounded wedge of McCarthy Formation ............................................................................................... 40 
Gabbro, diabase, and metagabbro, and cumulate mafic and ultramafic rocks. 40

Slana River subterrane - South of Broxson Gulch thrust and Denali fault and north of Eureka Creek fault ...... 41

Eagle Creek Formation (Early Permian) (Richter and Dutro, 1975) .........................................................43

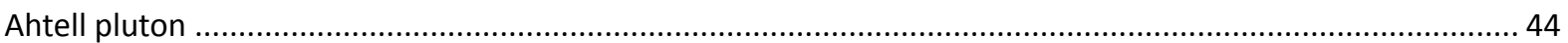

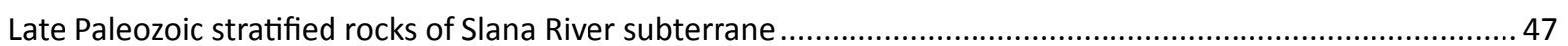

Tangle subterrane - South of Eureka Creek fault and north of Paxson Lake fault....................................... 52

Metamorphic complex of Gulkana River south of Paxson Lake fault ............................................................5 54

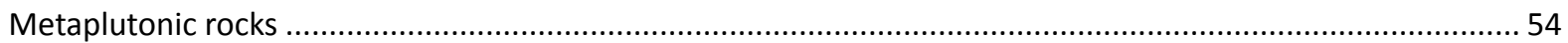

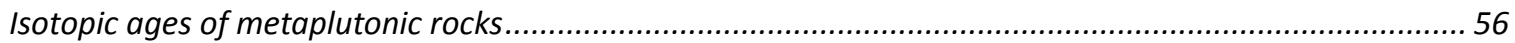

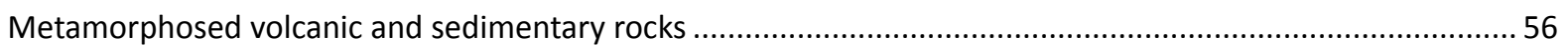

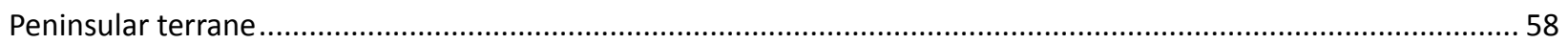

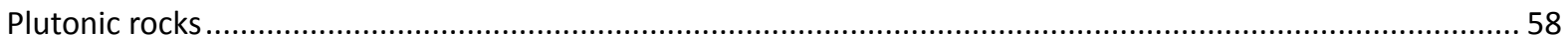

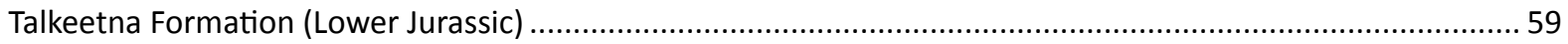

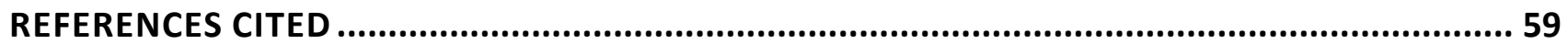

FIGURE

Figure 1. Generalized terrane and overlap assemblage map of eastern Southern Alaska and adjacent regions 2

\begin{tabular}{ccc} 
& \multicolumn{1}{c}{ SHEETS } & \\
Sheet 1 Gulkana C1 & 16 Mount Hayes A3 & 31 Mount Hayes C6 \\
2 Gulkana C2 & 17 Mount Hayes A4 & 32 Mount Hayes D2 \\
3 Gulkana C3 & 18 Mount Hayes A5 & 33 Mount Hayes D3 \\
4 Gulkana C4 & 19 Mount Hayes A6 & 34 Mount Hayes D4 \\
5 Gulkana C5 & 20 Mount Hayes B1 & 35 Mount Hayes D5 \\
6 Gulkana C6 & 21 Mount Hayes B2 & 36 Mount Hayes D6 \\
7 Gulkana D1 & 22 Mount Hayes B3 & 37 Nabesna C6 \\
8 Gulkana D2 & 23 Mount Hayes B4 & 38 Nabesna D4 \\
9 Gulkana D3 & 24 Mount Hayes B5 & 39 Nabesna D5 \\
10 Gulkana D4 & 25 Mount Hayes B6 & 40 Nabesna D6 \\
11 Gulkana D5 & 26 Mount Hayes C1 & 41 Tanacross A4 \\
12 Gulkana D6 & 27 Mount Hayes C2 & 42 Tanacross A5 \\
13 Mount Hayes A1_north & 28 Mount Hayes C3 & 43 Tanacross A6 \\
14 Mount Hayes A1_south & 29 Mount Hayes C4 & 44 Tanacross B5 \\
15 Mount Hayes A2 & 30 Mount Hayes C5 & 45 Tanacross B6
\end{tabular}




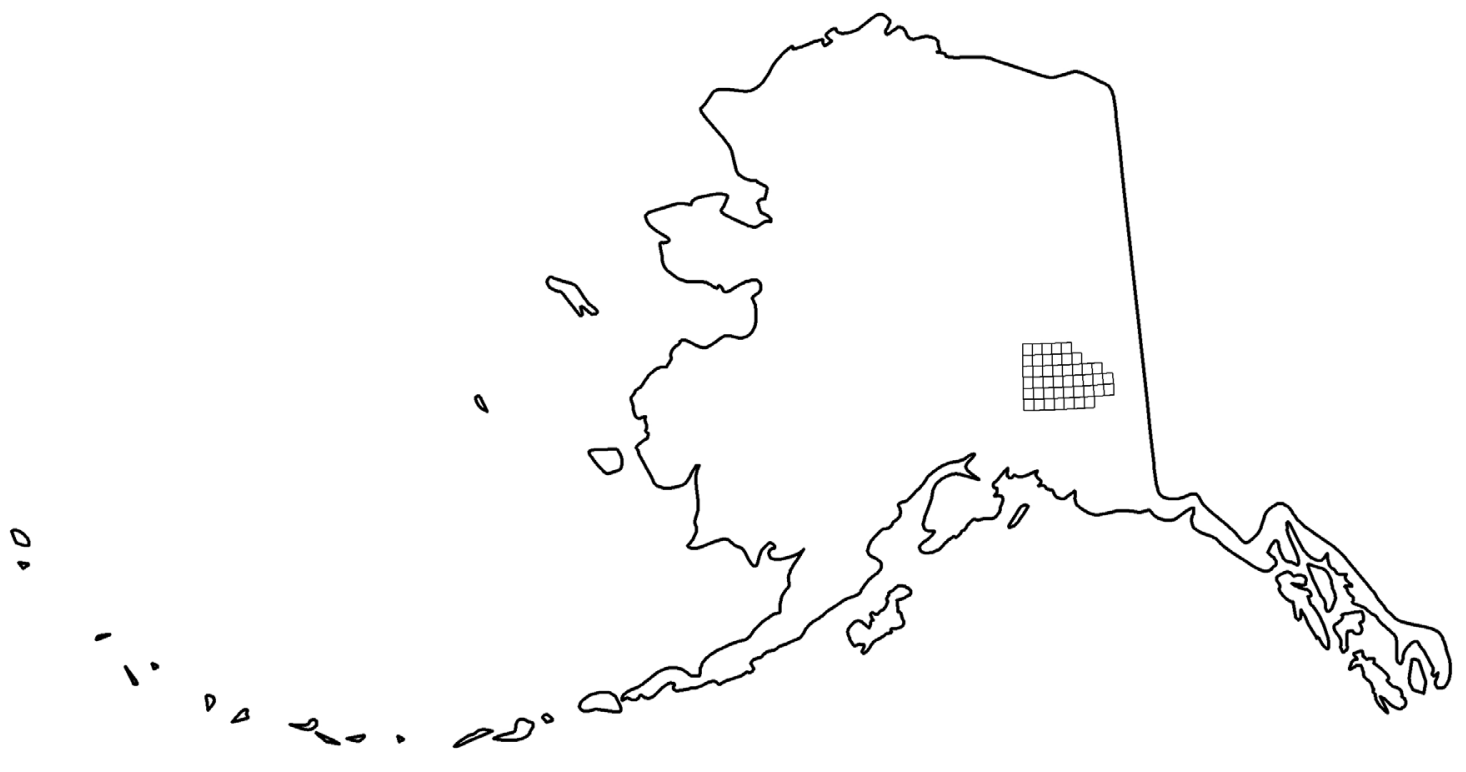

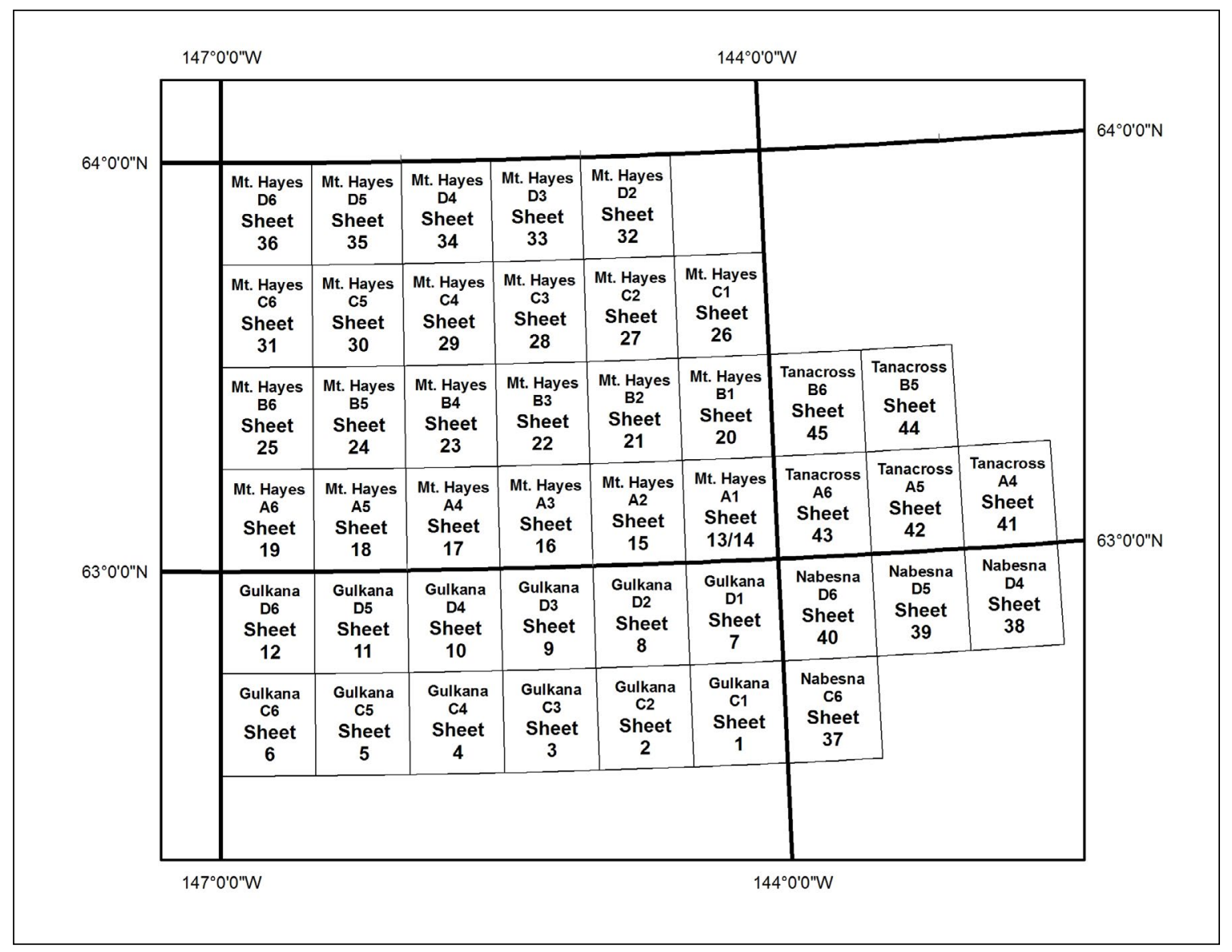





\section{GEOLOGIC MAPS OF THE EASTERN ALASKA RANGE, ALASKA, (44 QUADRANGLES, 1:63,360 SCALE) DESCRIPTIONS AND INTERPRETATIONS OF MAP UNITS}

Warren J. Nokleberg ${ }^{1}$, John N. Aleinikoff ${ }^{2}$, Gerard C. Bond ${ }^{3}$, Oscar J. Ferrians ${ }^{4}$, Paige L. Herzon ${ }^{5}$, Ian M. Lange ${ }^{5}$, Ronny T. Miyaoka ${ }^{5}$, Donald H. Richter ${ }^{4}$, Carl E. Schwab ${ }^{5}$, Steven R. Silva ${ }^{5}$, Thomas E. Smith ${ }^{6}$, and Richard E. Zehner

\section{INTRODUCTION}

\section{GENERAL INFORMATION AND TOPOGRAPHIC SETTING OF THE EASTERN ALASKA RANGE}

This report provides a description of map units for a suite of 44 inch-to-mile $(1: 63,360$-scale) geologic maps of the eastern Alaska Range. This report also contains a geologic and tectonic summary and a comprehensive list of references pertaining to geologic mapping and specialized studies of the region. In addition to the geologic maps of the eastern Alaska Range, this package includes a list of map units and an explanation of map symbols and abbreviations. The geologic maps display detailed surficial and bedrock geology, and structural and stratigraphic data; they also portray the active Denali fault that bisects the core of the east-westtrending range, and other young faults along the north and south flanks of the range.

The eastern Alaska Range forms a great glacially sculptured arcuate mountain range extending approximately $1,000 \mathrm{~km}$ from the Canada border in the east to the Aleutian Range to the west and southwest. The eastern Alaska Range is characterized by rugged peaks ranging to more than 4,180 $\mathrm{m}$ in elevation, and spectacular valley glaciers up to $65 \mathrm{~km}$ long. The range is bisected by the Denali fault, which is a major geographic, geologic, and tectonic boundary between the Yukon River basin in interior Alaska to the north, and the Copper River Basin of southern Alaska to the south. The geographic region portrayed on the geologic maps of the eastern Alaska Range consists of the Mount Hayes, northern Gulkana, southwestern Tanacross, and northwestern Nabesna 1:250,000-scale topographic quadrangles. The locations of these quadrangles are shown on figure 1.

Localities, geologic units, and faults described in this report are generally designated by geography and/ or by reference to the twenty-four 15-minute quadrangles (scale 1:63,360) that constitute each of the various $1^{\circ} \times 3^{\circ}$ (1:250,000-scale) quadrangles. These quadrangles, comprising 15 minutes of latitude and 30 minutes of longitude, are assigned numbers from east to west and are lettered from south to north. For example, the southernmost row in each $1^{\circ} \times 3^{\circ}$ quadrangle is designated from A- 1 in the east to A- 6 in the west, with successive rows of B-1 to B-6, C-1 to C-6, and D-1 to D-6 quadrangles to the north, numbered in a similar fashion from 1 in the east to 6 in the west.

The 1:63,360-scale quadrangles comprising the suite of geologic maps of the eastern Alaska Range are: (1) The Mount Hayes A-1 through A-6, B-1 through B-6, C-1 through C-6, and D-1 through D-6 quadrangles; (2) the Gulkana C-1 through C-6 and D-2 through D-6 quadrangles; (3) parts of the the Nabesna C-6 and D-4 through D-6 quadrangles; and (4) parts of the Tanacross A-4, A-5, A-6, B-5, and B-6 quadrangles. This area comprises the high glaciated parts of the eastern Alaska Range, and the lower foothills to the north and south.

\section{GEOLOGIC SETTING OF THE EASTERN ALASKA RANGE}

The following summary of the geology and tectonics of the eastern Alaska Range is mainly adapted from Nokleberg and others (2000) and Nokleberg and Richter (2007).

\section{Terranes north of the Denali fault}

North of the Denali fault, the eastern Alaska Range is underlain by the major Yukon-Tanana metamorphosed continental-margin arc terrane (fig. 1) that consists of a Late Devonian and Early Mississippian continental-margin igneous arc composed of middle Paleozoic sedimentary rock and intermediate to siliceous volcanic and granitic plutonic rock. The arc is interpreted to have formed along the North American craton margin, but was subsequently rifted away in the middle Mississippian and reaccreted in the Late Jurassic.

\section{Terranes along the Denali fault}

Along the Denali fault, the eastern Alaska Range is underlain by several narrow terranes. These terranes are the Aurora Peak and Maclaren continental-margin arc terranes, the Pingston and Windy mélange terranes, and a terrane of ultramafic and associated rocks (fig. 1).

\footnotetext{
${ }^{1}$ U.S. Geological Survey, MS 904, 945 Middlefield Road, Menlo Park, CA 94025; wnokleberg@usgs.gov

${ }^{2}$ U.S. Geological Survey, PO Box 25585, Denver Federal Center, Lakewood, CO 80225-0585; jaleinikoff@usgs.gov

${ }^{3}$ Lamont-Doherty Observatory, 61 Route 9W, Palisades, NY 10964

${ }^{4}$ U.S. Geological Survey, 4210 University Drive, Anchorage, AK 99508

${ }^{5}$ U.S. Geological Survey, MS 904, 945 Middlefield Road, Menlo Park, CA 94025

${ }^{6}$ Alaska Division of Geological \& Geophysical Surveys, 3354 College Road, Fairbanks, AK 99709-3707
} 

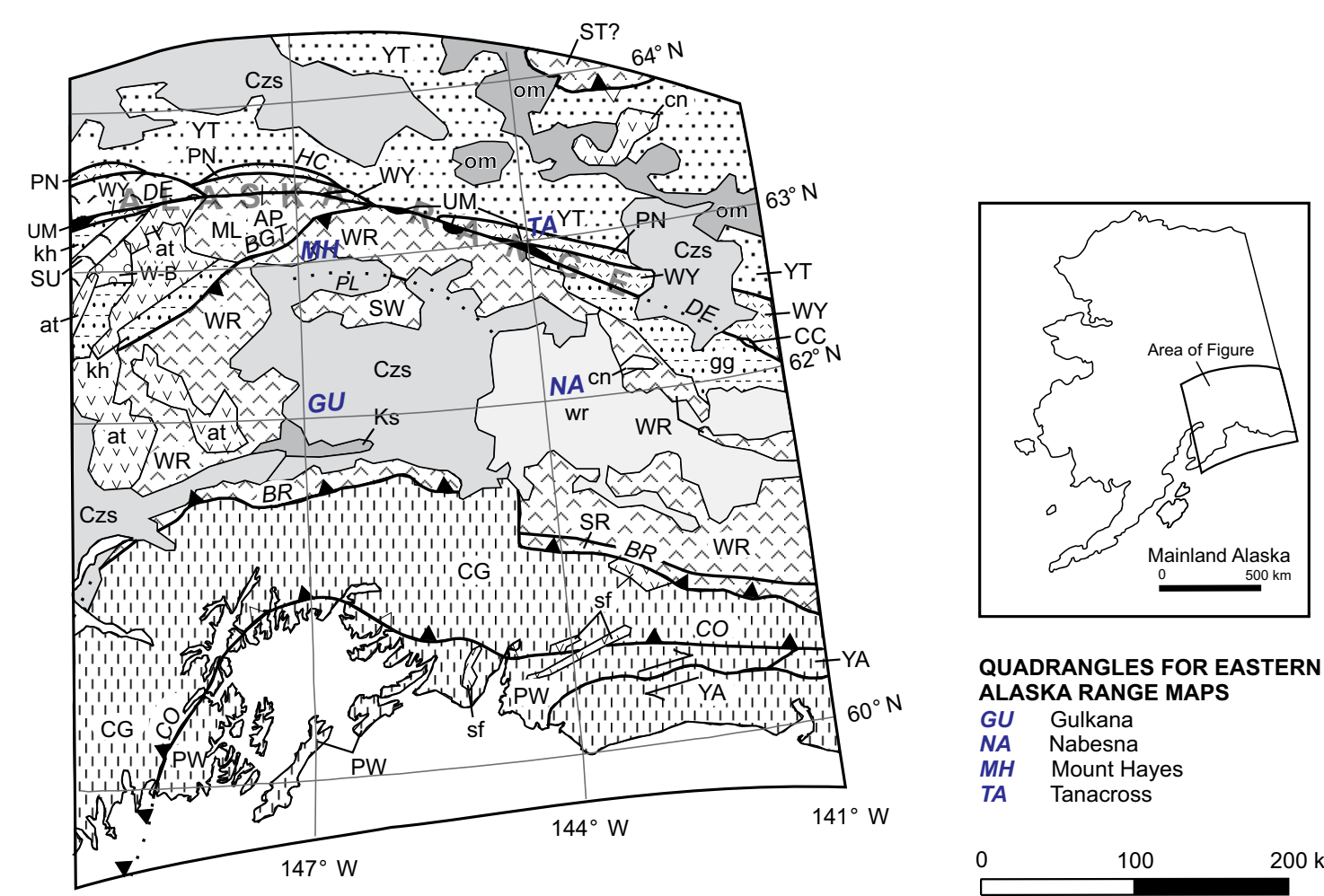

ALASKA RANGE MAPS

GU Gulkana

NA Nabesna

MH Mount Hayes

TA Tanacross

$150^{\circ} \mathrm{W}$

METAMORPHOSED CONTINENTALMARGIN TERRANE

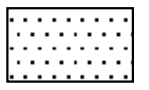

YT, Yukon-Tanana

ISLAND ARC TERRANES

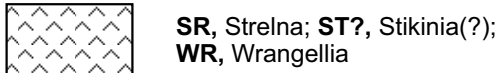

CONTINENTAL-MARGIN ARC TERRANES

AP, Aurora Peak; CC, Cottonwood

Creek; ML, Maclaren

\section{ACCRETIONARY-WEDGE AND} SUBDUCTION-ZONE TERRANES

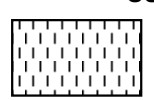

CG, Chugach; PW, Prince William;

YA, Yakutat;

\section{EXPLANATION}

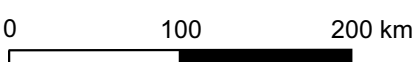

OVERLAP ASSEMBLAGES:

CENOZOIC AND MESOZOIC SEDIMENTARY AND

IGNEOUS ROCKS IN MAJOR SEDIMENTARY BASINS,

Quaternary and

late Tertiary

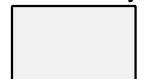

wr, Wrangell volcanic arc

Cenozoic

Czs, undivided sedimentary and

lesser volcanic rock units

Early Tertiary and

Late Cretaceous

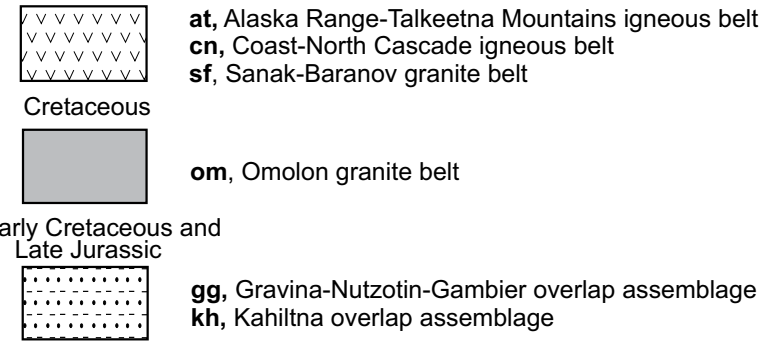

OCEANIC CRUST, SEAMOUNT,

ถั่า

AND OPHIOLITE TERRANES

SU, Suitna

TURBIDITE BASIN TERRANE

W-B, West Fork and Broad Pass

ULTRAMAFIC AND MAFIC TERRANE

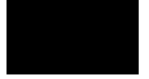

UM, Terrane of Ultramafic and

Associated Rocks

MELANGE

PN, Pingston; WY, Windy

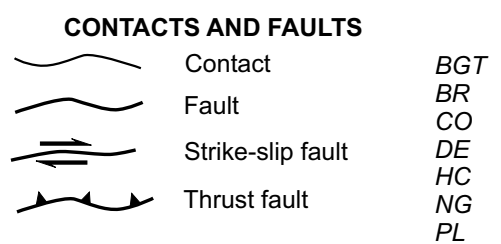

\section{FAULT NAMES}

Broxson Gulch Thrust Border Ranges Fault Contact Fault

Denali Fault

Healy Creek Fault Nenana Glacier Fault Paxson Lake Fault

Figure 1. Generalized terrane and overlap assemblage map of eastern Southern Alaska and adjacent regions. Adapted from Nokleberg and Richter (2007). Also depicted are topographic quadrangles covering eastern Alaska Range. 
The Aurora Peak and Maclaren continental-margin arc terranes consist mainly of Late Cretaceous to early Tertiary granitic rocks that intrude Mesozoic metamorphosed flysch and Paleozoic continental-margin sedimentary rocks. Both terranes are interepreted as tectonically displaced from similar suites of granitic plutonic and metasedimentary rocks in the northern part of the Coast Range batholith in northern Southeast Alaska. These two terranes are separated by the Denali fault, indicating early tectonic translation of the Aurora Peak terrane, followed by later tectonic translation of the Maclaren terrane.

The Pingston and Windy mélange terranes (fig. 1) contain diverse suites of highly deformed and structurally imbricated Paleozoic craton-margin sedimentary rocks and Mesozoic sedimentary and volcanic rocks that extend for several hundred kilometers adjacent to the Denali fault. The suites of rocks are interpreted as tectonic fragments of the North American craton margin or as offscrapings of the Wrangellia island-arc terrane.

The terrane of ultramafic and associated rocks (fig. 1) consists chiefly of ultramafic and mafic rocks, with lesser metasedimentary rocks and granitic rocks. It represents part of a string of alpine peridotites that occur along or near the Denali fault for several hundred kilometers in east-central Alaska. The terrane is interpreted as a crustal-suture belt composed of fragments of either oceanic or deep-level continental lithosphere.

\section{Terranes south of the Denali fault}

South of the Denali fault is the major Wrangellia islandarc terrane (fig. 1). This terrane consists of four major rock sequences: (1) A late Paleozoic sequence of sedimentary, volcanic, and granitic plutonic rocks that constitute the Skolai island arc; (2) a Late Triassic to Early Jurassic Peninsular island arc sequence composed mainly of volcanic and plutonic rock that constitute the Talkeetna island arc; (3) a Middle and Late Triassic sequence of the Nikolai Greenstone (metamorphosed basalt) and capping limestone that formed in a major rifting event; and (4) the Late Jurassic to Early Cretaceous Gravina-Nutzotin overlap assemblage that consists of flysch and volcanic rock basins that are portions of the Gravina-Chisana igneous arc that formed on the leading edge of the Wrangellia terrane.

South of the Wrangellia terrane is the metamorphic complex of Gulkana River (fig. 1), which extends for several hundred kilometers along the southern margin of the Wrangellia terrane. The metamorphic complex consists of: (1) Penetratively deformed and regionally metamorphosed Late Jurassic granitic and gabbroic plutonic rocks; (2) massive to weakly schistose, weakly metamorphosed upper Paleozoic(?) hornblende andesite and lesser clinopyroxene basalt; and (3) metamorphosed upper Paleozoic(?) pelitic and calc-schist, and quartz-feldspar schist. The metamorphic complex has been correlated with the lithologically similar Haley Creek metamorphic assemblage in the northern Valdez Quadrangle to the southeast. Together, these fault-bounded units are interpreted as fragments of a late Paleozoic to Late Jurassic island or continental-margin arc.

\section{Late Mesozoic to middle Tertiary granitic plutonic belts}

Two major sequences of late Mesozoic and early Cenozoic granitic plutons intrude terranes both north and south of the Denali fault. To the north of the Denali fault is the mid Cretaceous Omolon anatectic granite belt, which is interpreted as forming during and immediately after the accretion of the Wrangellia terrane. To the south of the Denali fault is the early Tertiary and Late Cretaceous Alaska Range-Talkeetna Mountains igneous belt, which is interpreted as forming during subduction of the outboard Chugach and Prince William terranes. Also south of the Denali fault, near the coastline of southern Alaska, is the middle Tertiary Sanak-Baranof belt, which is interpreted as forming during underthrusting of the Kula-Farallon oceanic ridge beneath the margin of southern Alaska.

\section{Tertiary sedimentary and volcanic rocks}

An extensive array of Tertiary sedimentary and volcanic rocks overlaps the bedrock along the northern and southern flanks of the eastern Alaska Range. The major groups are the Nenana Gravel (lower Pliocene to upper Miocene), the Jarvis Creek coal field (early Tertiary), sandstone, conglomerate, and various small units of intermediate to siliceous volcanic flows, tuff, dikes, and sills. Some Tertiary sedimentary and volcanic rocks are offset along major dextral-slip faults (such as the Denali and Hines Creek faults in the Mount Hayes Quadrangle), or are overthrust by bedrock along a series of range-core-dipping thrust faults that are present on both the southern and northern flanks of the eastern Alaska Range (best depicted in the Mount Hayes Quadrangle). Refer to the List of Map Units for a summary of all the Tertiary sedimentary and volcanic rock units.

\section{Quaternary surficial deposits, glaciers, and ice fields}

An extensive array of Quaternary surficial deposits overlaps the bedrock and many (but not all) of the major faults in the eastern Alaska Range. The major groups of surficial deposits are young, unconsolidated sediments (alluvial, colluvial, rock glacier, fluviolacustrine, and others) and glacial (moraines, glaciofluvial, drift, and others).

The most extensive Quaternary surficial units are lacustrine deposits formed in the Copper River basin in the proglacial Lake Atna that covered most of the southern two-thirds of the Gulkana Quadrangle, and adjacent areas to the south and east. The lake formed repeatedly during the major Pleistocene glaciations when drainage was blocked by glaciers in the Copper River, and which presently (and periodically in the Pleistocene between major glacial epochs) drains southward from the basin to the Gulf of Alaska.

The youngest surficial unit in the high parts of the eastern Alaska Range is a complex and extensive suite of glaciers and ice fields. Many glaciers, such as Canwell and Black 
Rapids, are present along major active faults, in this case, the dextral-slip Denali fault. Along the Hines Creek fault in the northwestern Mount Hayes Quadrangle, some major glacial canyons display dextral offset along this fault. And along the McCallum Creek-Slate Creek thrust in the southcentral part of the Mount Hayes Quadrangle, Wisconsin-age glacial moraine is overthrust by late Tertiary volcanic rock.

Refer to the List of Map Units for a list of all surficial units.

\section{Major faults}

Five major faults or sutures separate terranes in the eastern Alaska Range, and are shown on figure 1. (1) The Hines Creek fault (HC) separates the Yukon-Tanana terrane to the north from the Pingston and Windy terranes to the south. (2) The Nenana Glacier fault (NG) separates the Aurora Peak terrane to the north from the Maclaren, Pingston, and Windy terranes to the south. (3) The Denali fault (DE) is observed between the Yukon-Tanana, Aurora Peak, Pingston, and Windy terranes to the north and the Maclaren and Wrangellia terranes to the south. (4) The Broxson Gulch thrust (BGT) separates the Maclaren terrane to the north from the Wrangellia terrane to the south. Last, (5) the Paxson Lake fault (PL) separates the Wrangellia terrane to the north from the metamorphic complex of Gulkana River to the south.

Most of these major faults formed during accretion of terranes in the Late Cretaceous and early Cenozoic. However, the Hines Creek and Denali faults display late Tertiary ages, including Pliocene to Recent movement. For the Hines Creek fault (and associated Trident Glacier and McGinnis Glacier faults) in the northwestern Mount Hayes Quadrangle, these geologic maps reveal that the older bedrock of the middle Paleozoic Yukon-Tanana terrane is: (1) juxtaposed against late Pliocene to early Pleistocene glacial moraines along south-dipping thrust or strike-slip faults; and (2) juxtaposed against Oligocene to Pliocene sedimentary rocks along southdipping thrust or strike-slip faults.

On the Denali fault on November 3, 2002, the largest inland earthquake in North America in almost 150 years struck Alaska. Thousands of resultant landslides and rock avalanches occurred in the Alaska Range, with the largest slide on Black Rapids Glacier. The earthquake caused significant damage to the transportation systems in central Alaska. The Trans-Alaska Pipeline, which crosses the Denali fault in the eastern Alaska Range (in the center of the Mount Hayes B-4 Quadrangle), experienced $4.3 \mathrm{~m}$ (14 ft) of dextral (right-lateral) and $0.76 \mathrm{~m}(2.5 \mathrm{ft})$ of vertical displacement. Fortunately, because of good engineering, neither a rupture nor an oil spill occurred. For more information on the 2002 Denali fault earthquake, see DGGS Report of Investigations 2011-1, or USGS Fact Sheet 014-03.

\section{Tectonic summary}

The various terranes comprising the eastern Alaska Range were accreted and modified during two major tectonic events: Mid Cretaceous accretion of the Wrangellia island-arc terrane and associated subduction zone complexes and genesis of the tectonically linked Omolon anatectic granite belt; and starting in about the Late Cretaceous, dextral transport of the Wrangellia terrane along the Denali fault to the current site against the Yukon-Tanana terrane. These two major tectonic events caused: (1) Entrapment of a lens of oceanic lithosphere along the suture belt between the Wrangellia terrane and the North American craton margin and outboard accreted terranes to form the terrane of ultramafic and associated rocks; (2) subsequent dextral translation along the Denali fault of the terrane of ultramafic and associated rocks; (3) dextral translation along the Denali fault of the Aurora Peak and Maclaren continental-margin arc terranes from part of the Coast plutonic-metamorphic complex (Coast-North Cascade plutonic belt) in the southwestern Yukon Territory or northern Southeast Alaska; and (4) formation and dextral transport along the Denali fault of the mélange of the Windy and Pingston terranes from fragments of the Gravina-Nutzotin-Gambier volcanic-plutonic-sedimentary belt and scraps of the North American craton margin. During dextral tectonic translation of terranes along the Denali fault, various small units of early Tertiary volcanic rocks and small plutons formed as the eastern part of the Alaska Range-Talkeetna Mountains igneous belt. And in the late Tertiary, small units of Tertiary volcanic rock and tuff formed near the Denali fault.

\section{DESCRIPTION OF GEOLOGIC MAPPING}

For the Mount Hayes and northern Gulkana quadrangles, field mapping was conducted during the summers of 1978 through 1982 as part of the Alaska Mineral Resource Assessment Program (AMRAP), with additional topical studies and field mapping in the summers of 1983, 1985, 1986, and 1988 as part of the Trans-Alaskan Crustal Transect (TACT) program (Fuis and others, 2008). The investigation of regional geology, deep crustal structure, and tectonics, in conjunction with comprehensive geologic mapping, provides a scientific basis for regional structural and tectonic analysis and interpretation.

Most of the geologic mapping in the Mount Hayes Quadrangle was conducted with daily helicopter support for a group of about six geologists. Geologic mapping was generally conducted by two pairs of geologists doing foot traverses along ridges and streams with helicopter support, and with a third pair of geologists conducting high-country mapping and sampling by helicopter with numerous spot landings. Field seasons varied from two weeks to 30 and 60 days.

Bedrock geologic mapping was conducted in the northern half of the Gulkana Quadrangle, northwestern Nabesna Quadrangle, and southwestern Tanacross Quadrangle during the summers of 1983, 1985, 1986, and 1988. Because of lower relief compared to the Mount Hayes Quadrangle, geologic mapping in these quadrangles was generally conducted by three pairs of geologists doing foot traverses or along ridges and streams with helicopter support. The field seasons were generally two weeks.

For each 1:63,360-scale quadrangle, location data for geologic contacts, faults, and sample sites were transferred from paper field sheets onto master geologic compilation 
mylar maps, one set for geology and another set for sample sites. The master compilations, which were prepared by or under the close supervision of W.J. Nokleberg, were subsequently scanned and georegistered for this report. Geologic mapping from relevant literature, as described below, was also incorporated into the master compilations.

\section{PRIOR GEOLOGIC MAPPING}

For this region of the eastern Alaska Range, previous bedrock and surficial geologic mapping was conducted by: Mendenhall (1900, 1905); Rohn (1900); Schrader (1900); Mendenhall and Schrader (1903); Moffit (1912, 1932, 1936, 1937, 1938a, 1938b, 1942, 1944, 1954); Grantz (1953); U.S. Army Corps of Engineers (1953, 1955, 1959, 1960a, 1960b); Wahrhaftig and Hickox (1955); Holmes and Benninghoff (1957); Péwé and Holmes (1964); Richter (1964, 1966, 1967, 1976); Holmes (1965); Holmes and Péwé (1965); Rose and Saunders (1965); Rose (1965, 1966a, 1966b, 1967); Holmes and Foster (1968); Foster (1970); Ferrians (1971); Weber (1971); Bond (1976); Stout (1976); Richter and others (1977, 1989), Williams and Galloway (1986), Nokleberg and others (1992b); Plafker and others (1992); and Nokleberg and others (2013).

Bedrock mapping from these publications constitutes about 10 to 15 percent of the geologic maps presented in this report, and in most cases, these areas were remapped using new methods.

Bedrock geologic mapping from the following publications, for specific areas, were used with only miminal field checking or remapping: (1) Wahrhaftig and Hickox (1955) for geologic mapping of the Jarvis Creek coal field in the Mount Hayes C-4 Quadrangle; (2) Bond (1976) for the Rainbow Mountain area in the Mount Hayes A-4 and B-4 quadrangles; and (3) Richter and others (1977) for the southern Mount Hayes A-1 and A-2 quadrangles.

Surficial geologic mapping from the following publications, for specific areas, were used with only miminal field checking or remapping: (1) U.S. Army Corps of Engineers $(1953,1955,1959,1960 \mathrm{a}, 1960 \mathrm{~b})$ for mapping adjacent to the Glenn and Richardson highways in the Mount Hayes and Gulkana quadrangles; (2) Holmes and Benninghoff (1957) for mapping in the Fort Greely area in the north-central Mount Hayes quadrangle; (3) Péwé and Homes (1964) for mapping of the Mount Hayes D-4 Quadrangle; (4) Homes and Péwé (1965) for mapping of the Mount Hayes D-3 Quadrangle; (5) Holmes and Foster (1968) for mapping of the Johnson River area in the northwestern Mount Hayes Quadrangle;, (6) Ferrians (1971) for mapping along the Richardson Highway in the Gulkana Quadrangle; (7) Weber (1971) for mapping adjacent to the Richardson Highway in the Gulkana and Mount Hayes quadrangles; and (8) Williams and Galloway (1986) for mapping of lake sediments in the Copper River Basin in the Gulkana and the southern Mount Hayes quadrangles.

Unpublished bedrock geologic maps were provided by: (1) G.C. Bond for the Chistochina River area in the Mount
Hayes A-2 Quadrangle; (2) T.E. Smith for the northwestern part of the Gulkana Quadrangle; and (3) J.H. Stout for the area adjacent to the Denali fault, west of the Delta River, in the Mount Hayes B-4 Quadrangle. Although these areas were remapped, these geologists were added as coauthors. Unpublished geologic mapping of the northwestern Nabesna Quadrangle was also contributed by the late coauthor D.H. Richter, who also participated in the remapping of these area and the southwestern Tanacross Quadrangle.

\section{DATA QUALITY}

This suite of scanned and georegistered geologic quadrangle maps includes spatial information about geologic units, ages, field sample locations, faults, structural features, and structural measurements. Geographic locations of contacts, faults, and samples were determined from visual inspection of topography in relation to the printed 1:63,360-scale topographic map sheets used in the field. The data are more comprehensive for ridges and streams that could be traversed on foot. In the high and rugged peaks of the Alaska Range, which contain abundant small to large glaciers and icefields and numerous steep-sided glacial cirques and U-shaped valleys, the mapping and sampling was conducted by helicopter spot landings on available and safe landing sites. The field data are less comprehensive in these areas. Locations of faults and contacts, and characteristics of units were verified in successive field seasons.

The petrologic and geochemical characteristics of bedrock units were described from analyses and descriptions of several thousand thin sections made from hand samples collected in the field, and from synthesis of a few hundred whole-rock chemical analyses made from hand samples collected in the field.

The geologic time units employed in this report are from the U.S. Geological Survey Division of Geological Time Fact Sheet 2010-3059 (U.S. Geological Survey, 2010), which lists and explains geologic time divisions.

\section{ACKNOWLEDGMENTS}

We are greatly indebted to the hard work and excellent science published by present and past geologists in the eastern Alaska Range. As described above, our work is in part based on their fine efforts and accomplishments. We are grateful to U.S.G.S. managers H.C. Berg, the late Donald Grybeck, the late E.M. MacKevett, Jr., A.T. Ovenshine, T.P. Miller, and G.R. Winkler, who greatly encouraged and supported the geologic mapping. We thank D.L. Campbell, the late Carl Huie, J.S. Lull, and George Plafker for assisting in parts of short field seasons of the bedrock geologic mapping. We also thank the late D.L. Jones and the late N.J. Silberling for their stimulating discussions of bedrock geology and tectonics. We thank helicopter pilots Michael Arline, Richard Rossiter, and Barry Roberts for their superb flying in an extremely difficult and remote area. We also thank Robert J. Miller and Thomas E. Moore for their constructive scientific reviews. 


\section{SUMMARY OF MAP UNITS}

\section{SURFICIAL UNITS}

Qs $\quad$ Undifferentiated surficial deposits (Holocene)

Qs/QI Undifferentiated surficial deposits (Holocene) and Glacial Lake Ahtna glaciofluvial deposits (Wisconsin)

Qa Alluvial deposits (Holocene)

Qaf Alluvial fan deposits (Holocene)

Qrg Rock glacier deposits (Holocene)

Ql Landslide (Holocene)

Qsp Silt and peat deposits (Holocene)

Qoa Older alluvium (late Pleistocene and early Holocene)

Qfl Fluviolacustrine deposits (Holocene and possible late Pleistocene)

Qc Colluvial deposits (Holocene)

Qcg Undifferentiated colluvial and glacial deposits (Holocene)

\section{GLACIAL DEPOSITS}

Qam End and lateral moraines of Alaskan glaciation (Holocene)

Qwm End and lateral moraines of Wisconsin glaciation (Holocene and Pleistocene)

Qwf Glaciofluvial deposits of Wisconsin glaciation (Holocene and Pleistocene)

Qwg Undifferentiated deposits of Wisconsin glaciation (Holocene and Pleistocene)

Qom Drift of older glaciations (Pleistocene)

Qof Alluvial-fan deposits of older glaciations (Pleistocene)

\section{TERTIARY SEDIMENTARY AND VOLCANIC ROCKS-NORTH OF DENALI FAULT}

Tn Nenana Gravel (lower Pliocene to upper Miocene)

Ts Sandstone (Pliocene, Miocene, and Oligocene)

$\mathrm{Tj} \quad$ Sedimentary rocks of Jarvis Creek coal field (early Tertiary)

Tju Upper member

Tjm Middle member

Tjl Lower member

$\mathrm{Tb} \quad$ Basalt (late Tertiary[?])

\section{POST-ACCRETIONARY ALKALIC MAFIC AND ASSOCIATED PLUTONIC ROCKS- NORTH OF DENALI FAULT}

la Lamprophyre, alkalic gabbro, and alkalic diorite (early Tertiary and Late Cretaceous)

md Monzonite and diorite (early Tertiary and Late Cretaceous)

\section{POST-ACCRETIONARY GRANITIC PLUTONIC ROCKS-NORTH OF DENALI FAULT}

grn1 Granitic unit 1 (early Tertiary and/or Late Cretaceous)

grn2 Granitic unit 2 (early Tertiary and/or Late Cretaceous)

grn3 Granitic unit 3 (early Tertiary and/or Late Cretaceous)

grn4 Granitic unit 4 (early Tertiary or Late Cretaceous)

grn5 Granitic unit 5 (early Tertiary or Late Cretaceous)

grn6 Granitic unit 6 (Late Cretaceous)

grn7 Granitic unit 7 (Late Cretaceous

grn8 Granitic unit 8 (early Tertiary)

grn9 Granitic unit 9 (Late Cretaceous)

grn10 Granitic unit 10 (Late Cretaceous)

\section{POST-ACCRETIONARY MAFIC PLUTONIC ROCKS-NORTH OF DENALI FAULT}

mgb Gabbro, diorite, metagabbro, metadiorite, metadiabase, and amphibolite (Cretaceous) 
TERRANES-NORTH OF DENALI FAULT (FROM NORTH TO SOUTH)

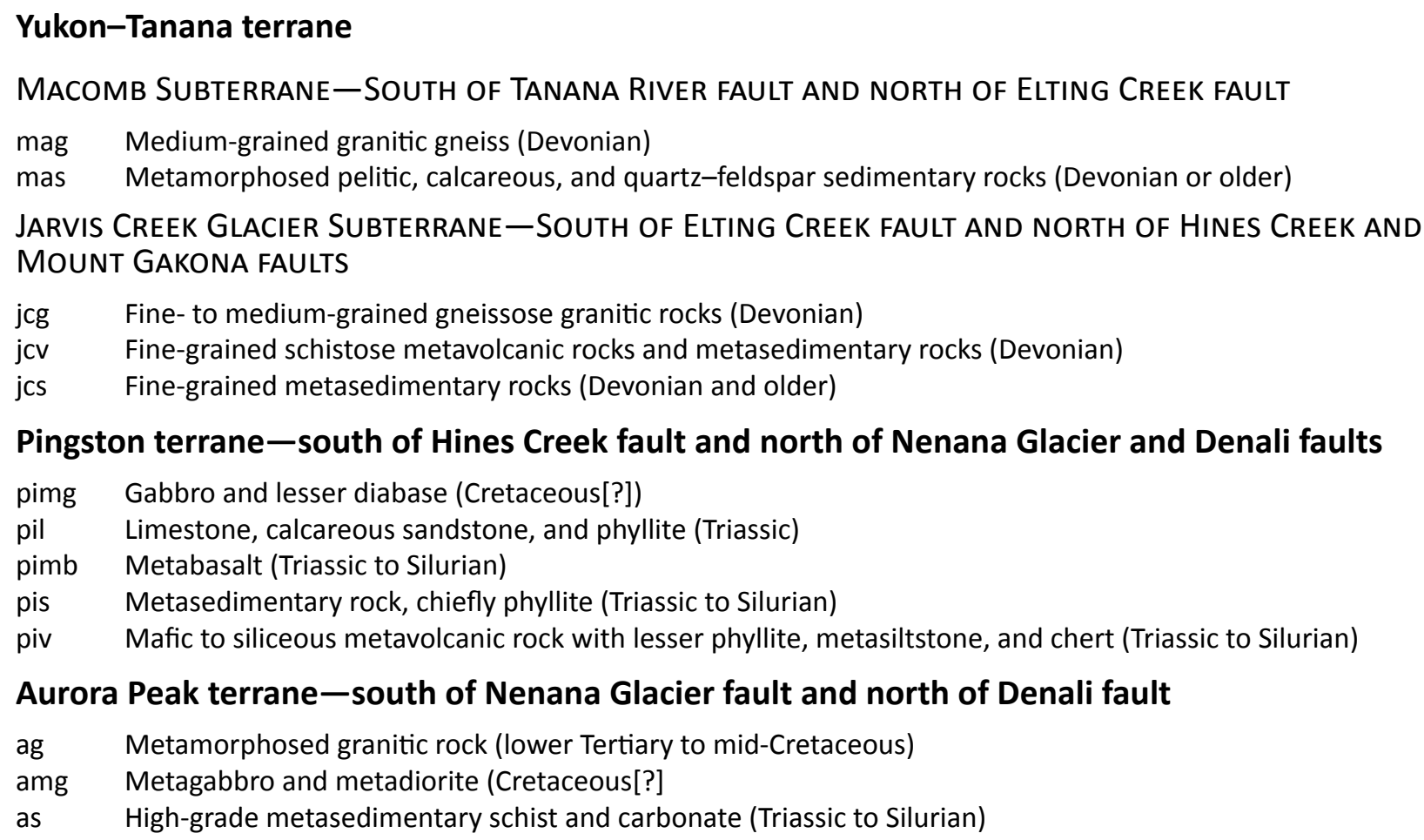

\section{POST-ACCRETIONARY GRANITIC PLUTONIC ROCKS AND DIKES AND SILLS- SOUTH OF DENALI FAULT}

grs1 Granitic unit 1 (Cretaceous and Late Jurassic)

grs2 Granitic unit 2 (Cretaceous and Late Jurassic)

grs3 Granitic unit 3 (Cretaceous and Late Jurassic)

\section{TERRANES-SOUTH OF DENALI FAULT (FROM NORTH TO SOUTH)}

Terrane of ultramafic and associated rocks-in branches of Denali fault

umg Granite and tonalite (Cretaceous[?] or older)

ump Peridotite and pyroxenite and minor dunite (Cretaceous[?] or older)

umd Dunite (Cretaceous[?] or older)

uma Amphibolite and hornblende-plagioclase gneiss (Cretaceous[?] or older) 


\section{Ultramafic and mafic rocks-within branches of Broxson Gulch thrust}

um Ultramafic and mafic igneous rocks (Cretaceous to Triassic)

\section{Maclaren terrane-south of Denali fault and north of Broxson Gulch thrust} EAST SUSITNA BATHOLITH, AND SCHIST, QUARTZITE, AND AMPHIBOLITE-SOUTH OF DENALI FAULT AND
NORTH OF METEOR PEAK FAULT

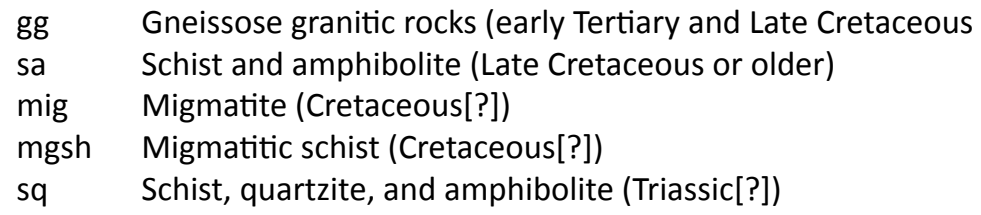

Maclaren Glacier metamorphic Belt-SOUth of Meteor PeAK faUlt ANd NORTH of BROXSON GULCH THRUST

msh Quartz-mica schist, calc-schist, and amphibolite (Late Jurassic or older)

mph Phyllite (Late Jurassic or older)

\section{Clearwater terrane-within branches of Broxson Gulch thrust}

$\mathrm{cm} \quad$ Schistose marble (Triassic)

csm Schistose metasedimentary and metavolcanic rocks (Late Triassic)

\section{Wrangellia terrane-south of Broxson Gulch thrust and Denali fault}

\section{FAULT-BOUNDED WEDGE OF MCCARTHY FORMATION}

$\mathrm{J} \mathrm{km} \quad \mathrm{McCarthy}$ Formation (Early Jurassic and Late Triassic)

GABBRO, DIABASE, AND METAGABBRO, AND CUMULATE MAFIC AND ULTRAMAFIC ROCKS

kg Gabbro, metagabbro, and diabase (Late Triassic[?])

kcg Clinopyroxene-hornblende stocks and plugs (Late Triassic[?])

koc Olivine cumulate (Late Triassic[?])

Kopc Olivine-pyroxene cumulate (Late Triassic[?])

kppc Pyroxene-plagioclase cumulate (Late Triassic[?])

SLANA River SubTERRANe-SOUth OF BROXSON GULCH THRUST AND DENALI FAULT AND NORTH OF EUREKA CREEK FAULT

KJs Marine metasedimentary rocks (Early Cretaceous and Late Jurassic)

$\mathrm{k}$ Limestone (Late Triassic)

$\mathrm{kn} \quad$ Nikolai Greenstone (Late to Middle Triassic)

Eagle Creek formation (Early Permian)

Peua Upper argillite member

Peul Upper limestone member

Pela Lower argillite member

Pell Lower limestone member

Pea Argillite unit, not subdivided

Pel Limestone unit, not subdivided

$\mathrm{Pi} \quad$ Shallow-level intrusive stocks, dikes, sills, and small plutons (Early Permian[?])

Ahtell Pluton (Middle to Early Pennsylvanian)

PPfg Fine-grained biotite granite (Middle to Early Pennsylvanian)

PPpg Porphyritic hornblende granodiorite (Middle to Early Pennsylvanian)

PPg Biotite-hornblende granite and and lesser granodiorite (Middle to Early Pennsylvanian)

PPgd Biotite-hornblende granodiorite (Middle to Early Pennsylvanian)

PPad Altered diabase and gabbronorite (Middle to Early Pennsylvanian) 
PPdg Diorite and lesser granodiorite (Middle to Early Pennsylvanian)

$\mathrm{PPd} \quad$ Diorite and lesser granodiorite, and gabbronorite (Middle to Early Pennsylvanian)

$\mathrm{PPg} \quad$ Granitic plutons (Pennsylvanian)

qfs Quartz-Feldspar Schist (Mid to early Paleozoic[?])

\section{LATE PALEOZOIC STRATIFIED ROCKS OF SLANA RIVER SUBTERRANE}

PPs Slana Spur Formation (Early Permian to Middle Pennsylvanian)

$\mathrm{PPsu}$ Calcareous volcaniclastic rocks member

PPsI Volcaniclastic rocks member

Pt Tetelna Volcanics (Pennsylvanian)

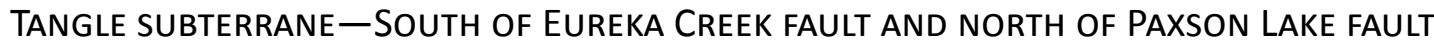

$\mathrm{KI} \quad$ Limestone (Late Triassic)

$\mathrm{kn} \quad$ Nikolai Greenstone (Late or Middle Triassic)

Knf Subaerial basalt flows member

knp Pillow basalt flows member

$\mathrm{kt} \quad$ Aquagene tuff, argillite, limestone, chert, andesite tuff, and greenstone (late Paleozoic)

\section{Metamorphic complex of Gulkana River-south of Paxson Lake fault}

\section{METAPLUTONIC ROCKS}

sqm Schistose quartz monzonite (Late Jurassic)

sqd Schistose quartz diorite (Late Jurassic)

sgd Schistose granodiorite (Late Jurassic)

shd Schistose hornblende diorite (Late Jurassic)

shgb Schistose hornblende gabbro (Late Jurassic or older)

scgb Schistose clinopyroxene gabbro (Late Jurassic or older)

ag Amphibolite gneiss (Late Jurassic or older)

\section{METAMORPHOSED VOLCANIC AND SEDIMENTARY ROCKS}

mha Metamorphosed hornblende andesite (Upper Paleozoic[?] or older)

qmfs Quartz-muscovite-feldspar schist (Upper Paleozoic[?] or older)

$\mathrm{mmp}$ Metamorphosed pelitic and calc-schist (Upper Paleozoic[?] or older)

mcb Metamorphosed clinopyroxene basalt (Upper Paleozoic[?] or older)

am Amphibolite (Upper Paleozoic[?] or older)

\section{Peninsular terrane}

\section{PLUTONIC ROCKS}

hbqd Hornblende-biotite quartz diorite (Cretaceous or Jurassic)

hbqm Hornblende-biotite quartz monzonite (Cretaceous or Jurassic)

hbgd Hornblende-biotite granodiorite (Cretaceous or Jurassic)

\section{TALKEETNA FORMATION (LOWER JURASSIC)}

Jtrd Rhyodacite and dacite

Jta Hornblende andesite flows

Jts Sandstone and volcaniclastic rocks 


\section{EXPLANATION OF MAP SYMBOLS}

\section{CONTACTS AND FAULTS}

Contact--Solid where accurate, dashed where approximate, dotted where concealed

Fault--Solid where accurate, dashed where approximate, dotted where concealed

Thrust fault--Solid where accurate, dashed where approximate, dotted where concealed. Sawteeth on upper plate

Strike-slip fault, right-laterial offset--Sold where accurate, dashed where approximate, dotted where concealed. Arrows show relative motion

Note: Contacts and minor faults terminate against margins of water bodies (ponds, lakes, streams, rivers), ice fields, and glaciers. Major faults and contacts around granite plutons are dotted (inferred) under most water bodies, ice fields, and glaciers.

\section{SYMBOLS}

Antiforms, Anticlines, Synforms, and Synclines

- $\frac{1}{\ddagger} \cdot$ - Axial trace of regional antiform

$\longrightarrow$ Antiform or anticline; arrow at end indicates plunge

$\longrightarrow$ Synform or syncline; arrow at end indicates plunge

Overturned antiform

\section{Strike and Dip of Bedding}

\begin{tabular}{ll}
$\underset{\perp}{10}$ & Inclined-Showing strike and dip \\
\hdashline- & Vertical--Showing strike \\
30 & Overturned bedding
\end{tabular}

Strike and Dip of Foliation and Parallel Schistosity
$+10$
Inclined-Showing strike and dip
$\neg$
Vertical--Showing strike

Strike and Dip of Joints

$\begin{array}{ll}20 & \text { Inclined-Showing strike and dip } \\ - & \text { Vertical--Showing strike }\end{array}$

\section{Strike of Vertical Dike}

II

\section{Other Symbols}

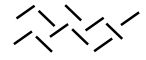

$M M M$ $M M M$

$\simeq \approx$

$\because \cdots \cdots$

$\therefore \cdots$

$\therefore: \because::$

gar no gar
Area of abundant dikes; rock type shown in parentheses

Area of extensive contact metamorphism

Highly brittle-sheared rock

Fe-stained zone

Area of wall rock inclusions in pluton

Retrogressive metamorphic isograd in Jarvis Creek Glacier subterrane where mineral to north of isograd is replaced by chlorite and other minerals to south of isograd. Abbreviations: bi - biotite; gar - garnet; ho - hornblende. 


\section{DESCRIPTION OF MAP UNITS}

\section{SURFICIAL UNITS}

Qs UNDIFFERENTIATED SURFICIAL DEPOSITS (Holocene) - Chiefly alluvial, colluvial, older alluvial, fluviolacustrine, and glacial deposits mainly in northern Gulkana Quadrangle.

Qs/Q1 UNDIFFERENTIATED SURFICIAL DEPOSITS (HOLOCENE) AND GLACIAL LAKE ATNA GLACIOFLUVIAL DEPOSITS (Wisconsin) - Mainly in Gulkana Quadrangle.

Qa ALLUVIAL DEPOSITS (Holocene) - Chiefly floodplain and minor fans and cones. Primarily unconsolidated sand and gravel. Occurs as floodplains and adjacent low terraces. In places, floodplain deposits incised by dry channels.

Qaf ALLUVIAL FAN DEPOSITS (Holocene) — Broad cones emanating from canyons. Only large, well-defined cones differentiated from colluvium and alluvium. Mainly unconsolidated sand and gravel.

Qrg ROCK GLACIER DEPOSITS (Holocene) — Coarse, angular rubble from active and inactive rock glaciers. Locally mixed with till.

Q1 LANDSLIDE (Holocene) - Mixed coarse and fine unconsolidated debris deposited by larger landslides, earth flows, and avalanches.

Qsp SILT AND PEAT DEPOSITS (Holocene) — Chiefly mixtures of alluvial, eolian, and lacustrine silt mixed with peat and finely-divided organic material. Occurs in large and small depressions mainly in Tanacross A-4 and A-5 quadrangles.

Qoa OLDER ALLUVIUM (late Pleistocene and early Holocene) - Uplifted terraces along Delta River near Denali fault, consisting of floodplain deposits. Elsewhere, some deposits may be outwash from a late advance of the Wisconsin glaciation. Predominantly unconsolidated sand and gravel.

Qfl FLUVIOLACUSTRINE DEPOSITS (Holocene and possible late Pleistocene)-Lake, pond, and low-gradient stream deposits, mainly consisting of sand, silt, and clay.

Qc COLLUVIAL DEPOSITS (Holocene) - Chiefly talus and other slope-debris deposits. Primarily silt, sand, gravel, and rubble. Also includes alluvium of minor streams and, locally, glacial, rock glacier, and mass-wasting deposits. In areas of gentle slopes, consists mainly of mixed colluvium and alluvium with local bedrock rubble but may include older glacial drift deposits. Locally grades into deposits of Alaskan, Wisconsin, and older glaciations mainly consisting of rubble, gravel, sand, silt, and clay.

Qcg UNDIFFERENTIATED COLLUVIAL AND GLACIAL DEPOSITS (Holocene) ALONG SIDES OF MAJOR VALLEYS AND IN SMALL STREAM VALLEYS - Chiefly unconsolidated sand, and gravel. Occurs on steep valley walls as alluvial fans, alluvial-colluvial aprons, and talus cones mixed with glacial deposits. Also observed in narrow valley bottoms and low terraces. Grades into colluvium (Qc) and alluvium (Qa). Locally grades into deposits of Alaskan, Wisconsin, and older glaciations.

\section{GLACIAL DEPOSITS}

Qam END AND LATERAL MORAINES OF ALASKAN GLACIATION (Holocene)—Left after recession of existing glaciers. Mainly rubble and diamicton.

Qwm END AND LATERAL MORAINES OF WISCONSIN GLACIATION (Holocene and Pleistocene)—Poorly sorted and unstratified till of unconsolidated sand and gravel. Primarily rubble and diamicton; local sand and gravel. May locally include deposits of Alaskan glaciation (Qam). Ridges are steep-sided and contain closely spaced, slightly weathered boulders. Local ponds are common. Upper 0.2 to $0.4 \mathrm{~m}$ of till weathered. At higher elevations, deposits grade vertically with, and covered by, colluvium (Qc). Locally called Donnelly (late Wisconsin) glaciation.

Qwf GLACIOFLUVIAL DEPOSITS OF WISCONSIN GLACIATION (Holocene and Pleistocene) - Moderately well stratified layers and lenses of well-rounded gravel with matrix of silt and sand. Poorly to moderately well sorted with local lenses of well sorted sand. Generally occurs downslope from end moraines of Wisconsin glaciation. May locally include postglacial alluvium and pond deposits. Locally called Donnelly (late Wisconsin) glaciation.

Qwg UNDIFFERENTIATED DEPOSITS OF WISCONSIN GLACIATION (Holocene and Pleistocene)—Poorly sorted and unstratified sand, gravel, and conglomerate. May locally include deposits of Alaskan glaciation (Qam); local 
ponds are common. At higher elevations, deposits grade vertically with, and covered by, colluvium (Qc). Locally called Donnelly (late Wisconsin) glaciation.

Qom DRIFT OF OLDER GLACIATIONS (Pleistocene)—Primarily till, gravel, and sand. Also includes sand and very minor silt. Generally well stratified and fairly well sorted. Locally overlain by a few centimeters to a few meters of silt and fine sand. Includes both lateral and terminal moraine. At higher elevations, consists chiefly of unconsolidated diamicton and boulder deposits. At lower elevations, consists mainly of unconsolidated glaciofluvial deposits of moderately well stratified and sorted gravel and sand. Some moraines exhibit subdued geomorphic expression. Includes material that is partly colluvial. Probably of early Wisconsin or Illinoian age. Occurs beyond limit of Wisconsin moraines. Also includes undifferentiated high-level glacial deposits. At higher elevations, deposits merge with and covered by undifferentiated colluvium (Qc). At lower elevations, deposits merge with and covered by undifferentiated alluvium (Qa). Locally called Delta (early Wisconsin) glaciation.

Qof ALLUVIAL FAN DEPOSITS OF OLDER GLACIATIONS (Pleistocene)-Primarily well rounded gravel. Probable early Wisconsin or Illinoian age. Occurs beyond limit of Wisconsin moraines. Locally called Delta (early Wisconsin) glaciation.

\section{TERTIARY SEDIMENTARY AND VOLCANIC ROCKS - NORTH OF DENALI FAULT}

Scattered exposures of Tertiary continental sedimentary rocks occur north of the Denali fault and consist of, from youngest to oldest, the Nenana Gravel, a sandstone unit, and the sedimentary rocks and coal of the Jarvis Creek coal field (Wahrhaftig and Hickox, 1955). The Nenana Gravel occurs mainly in the northwestern corner of the Mount Hayes Quadrangle, and north of the Jarvis Creek coal field in the center of the Mount Hayes Quadrangle. The sandstone unit occurs mainly in fault-bounded prisms along the northern edge of the Alaska Range. The Jarvis Creek coal field occurs between the Delta River and Jarvis Creek, east of the Richardson Highway.

Tn NENANA GRAVEL (lower Pliocene to upper Miocene) - Consists chiefly of poorly cemented conglomerate but includes some sandstone and siltstone. Clast composition in Mount Hayes D-6 Quadrangle (in decreasing order of abundance) is schist, quartzite, granitic rocks, gabbro, and metagabbro. At one locality in Mount Hayes C-3 Quadrangle, clasts are approximately 80 percent schist, 10 percent quartz, and 10 percent felsic volcanic rocks, mafic volcanic rocks, and diabase. Bedding strikes northeast and dips gently south in Mount Hayes D-6 Quadrangle; and strikes northwest and dips moderately to steeply north near contact with fine-grained metasedimentary rocks of Jarvis Creek Glacier terrane (jcs) along Granite Mountain fault, in northern Mount Hayes C-3 Quadrangle. Eroded at top. Maximum exposed stratigraphic thickness of a few hundred meters.

Mainly exposed along northern Mount Hayes D-6 Quadrangle boundary, northeastern Mount Hayes C-4 Quadrangle, and northeastern Mount Hayes C-3 Quadrangle. Unconformably overlies granite of Granite Mountain (grn7) and fine-grained metasedimentary rocks (jcs) of Jarvis Creek Glacier subterrane; locally in fault contact with Jarvis Creek Glacier terrane (jcs). Unconformably overlain by Pleistocene glacial deposits, and overlies coal-bearing sedimentary rocks of Jarvis Creek coal field (Tj) inferred to be of early Tertiary age (Moffit, 1942; Wahrhaftig and Hickox, 1955), and locally unconformably overlies the sandstone unit of Oligocene to Pliocene age (Ts). Inferred to be late Tertiary (Pliocene). Lithologically similar to rocks assigned to Nenana Gravel that occur to the west in Healy Quadrangle and are assigned a Miocene(?) or Pliocene age by Csejtey and others (1992).

Ts SANDSTONE (Pliocene, Miocene, and Oligocene) - Chiefly brown sandstone and graywacke but includes some interbedded conglomerate and dark argillite. Generally fault bounded. Maximum exposed stratigraphic thickness of a few hundred meters.

Fine to medium grained, poorly sorted, angular, and grades into graywacke. Composition varies from quartz grains in a clay-rich matrix to quartz, plagioclase, K-feldspar, pyroxene, hornblende, and biotite in a clay-rich matrix. Conglomerate pebbles locally composed of granitic rocks and schist; locally imbricated. Argillite composed of tiny quartz grains and opaque minerals in a yellow-brown, clay-rich matrix.

Unit occurs in scattered exposures up to $3.5 \mathrm{~km}$ across in Mount Hayes C-5, C-6, D-5, and D-6 quadrangles. Strikes northeast and dips moderately west in Mount Hayes C-5 Quadrangle. Overlies and locally faulted against rocks of Jarvis Creek Glacier subterrane. Many occurrences too small to depict on geologic map. Largely surrounded by Quaternary deposits. Sparse plant fossils indicate Oligocene, Miocene, and Pliocene age (table 1 of Nokleberg and others [1992a], localities 1-4, 6).

$\mathrm{Tj}$ SEDIMENTARY ROCKS OF JARVIS CREEK COAL FIELD (early Tertiary) (unit of Wahrhaftig and Hickcox, 1955) - Chiefly sandstone, mudstone, conglomerate, and coal. Eroded at top. Occurs in an irregular outcrop approx- 
imately $10 \mathrm{~km}$ long, in the north-central part of Mount Hayes C-4 Quadrangle. Overlies bedrock of Jarvis Creek Glacier subterrane. Sparse plant fossils indicate a Tertiary age (table 1 of Nokleberg and others [1992a], locality 5). To the west in Healy Quadrangle, lithologically similar rocks in the Nenana coal field are Eocene to late Miocene in age (Wahrhaftig and others, 1969; Csejtey and others, 1992). Estimated maximum exposed stratigraphic thickness of about $600 \mathrm{~m}$. Locally divided into upper, middle, and lower members.

Tju UPPER MEMBER - Primarily dark gray mudstone and sandstone containing scattered coal beds. Eroded at top. Occurs in an irregular outcrop $4 \mathrm{~km}$ across in central Mount Hayes C-4 Quadrangle. Overlies finegrained metasedimentary rocks (jcs) of Jarvis Creek Glacier subterrane and the middle member (Tjm) of the sedimentary rocks of Jarvis Creek coal field. Estimated maximum exposed stratigraphic thickness of about $300 \mathrm{~m}$.

Tjm MIDDLE MEMBER - Mainly buff arkosic sandstone, containing claystone and scattered coal beds, and a prominent coal and shale zone at base. Occurs in an elongate, arcuate outcrop $9 \mathrm{~km}$ long in central Mount Hayes C-4 Quadrangle. Overlies fine-grained metasedimentary rocks (jcs) of Jarvis Creek Glacier subterrane and lower member (Tjl) of the sedimentary rocks of Jarvis Creek coal field. Estimated stratigraphic thickness of $300 \mathrm{~m}$ or less.

Tj1 LOWER MEMBER - Chiefly angular quartz sandstone and conglomerate; some claystone, and coal. Occurs in an irregular outcrop $4 \mathrm{~km}$ long in central Mount Hayes C-4 Quadrangle. Overlies fine-grained metasedimentary rocks unit (jcs) of Jarvis Creek Glacier subterrane. Estimated stratigraphic thickness of $150 \mathrm{~m}$ or less.

BASALT (late Tertiary[?]) — Porphyritic clinopyroxene basalt. Forms small outcrops in Tanacross A-5 Quadrangle.

\section{POST-ACCRETIONARY ALKALIC MAFIC AND ASSOCIATED PLUTONIC ROCKS - NORTH OF DENALI FAULT}

A suite of alkalic mafic and associated plutonic rocks occurs north of Denali fault in the Windy terrane, and in Hayes Glacier and southern Jarvis Creek Glacier subterranes of the Yukon-Tanana terrane. The suite consists of lamprophyre, alkalic gabbro, alkalic diorite, and monzonite, and diorite in dikes, sills, and small plutons. Many dikes and sills are too small to depict on the geologic map.

A variety of intricate, small plutons and dikes of lamprophyre, alkalic gabbro, monzonite, and diorite, partly surrounded by a ring dike of granite of Gerstle River (grn8) form a major intrusive suite in the Mount Hajdukovich area. The suite intrudes fine-grained metasedimentary rocks (jcs) of Jarvis Creek Glacier subterrane. Suite occupies an irregular area approximately 6 by $12 \mathrm{~km}$ in southeastern Mount Hayes C-3 and southwestern C-2 quadrangles.

The lamprophyres and alkalic gabbros and related rocks crosscut all penetrative structures and are younger than the intense Early to mid Cretaceous deformation and metamorphism of the Yukon-Tanana terrane, described below. The alkalic and related rocks occur only in units that are relatively near Denali fault, and not in deeper-level subterranes of the Yukon-Tanana terrane farther north.

LAMPROPHYRE, ALKALIC GABBRO, AND ALKALIC DIORITE (early Tertiary and Late Cretaceous) Undifferentiated dikes, sills, and small plutons. Predominantly fine- to medium-grained, panidiomorphic granular to porphyritic texture. Composed of phenocrysts, up to $3 \mathrm{~mm}$, of hornblende-rimmed clinopyroxene plagioclase, biotite, olivine, orthopyroxene, hornblende, and K-feldspar in a fine-grained groundmass of K-feldspar, plagioclase, biotite, quartz, calcite, chlorite, and minor white mica and opaque minerals. Common interstitial carbonate alteration. Some dikes almost completely replaced by carbonate.

Unit occurs in several irregular bodies up to $3 \mathrm{~km}$ across in southeastern Mount Hayes C-3 Quadrangle, and as an irregular body approximately $3 \mathrm{~km}$ across on southern Mount Hayes C-2 and C-3 quadrangle boundary. Intrudes fine-grained metasedimentary rocks (jcs) of Jarvis Creek Glacier subterrane.

The lamprophyres, alkalic gabbros, and alkalic diorites exhibit two clusters of K-Ar ages: (1) A suite of Late Cretaceous to early Tertiary biotite ages of 62.9, 67.6, and 69.2 Ma in the Robertson River area in east-central Mount Hayes Quadrangle (table 2 of Nokleberg and others [1992a], localities 9, 25, 26); and (2) a suite of mid to Late Cretaceous K-Ar ages of 75.6 Ma for hornblende, 69.3 Ma for biotite, and 107.6 Ma for hornblende in the Tok River area in east-central Mount Hayes Quadrangle (table 2 of Nokleberg and others [1992a], localities 29-31). Additional K-Ar hornblende age of 91.6 Ma to the east in southwestern Tanacross Quadrangle (Foley, 1982; 1984). These data indicate probable intrusion of alkalic mafic rocks mainly during Late Cretaceous and early Tertiary, 
with one sample apparently intruded in mid Cretaceous. No isotopic data available for Mount Hajdukovich area. The granite of Gerstle River (grn8), part of which forms a partial ring dike around, and small plutons within, the igneous suite of Mount Hajdukovich, exhibits K-Ar isotopic ages of 53.4 and $54.3 \mathrm{Ma}$ (table 2 of Nokleberg and others [1992a], localities 21, 24).

md MONZONITE AND DIORITE (early Tertiary and Late Cretaceous) - Includes lesser quartz monzonite and quartz diorite. Undifferentiated dikes, sills, and small plutons. Fine to medium grained; hypautomorphic-granular and locally porphyritic. Composed of plagioclase, $\mathrm{K}$-feldspar, hornblende, biotite, quartz, and minor clinopyroxene and sphene. Hornblende and clinopyroxene, partially replaced by biotite and hornblende, rims clinopyroxene. Locally schistose, fractured, and granulated. Locally altered with hornblende and biotite partially altered to chlorite and calcite, and plagioclase to sericite, and minor epidote and calcite. Unit occurs in southwestern Mount Hayes C-2 Quadrangle in two elongate outcrops up to $2.5 \mathrm{~km}$ long that extend westward into Mount Hayes C-3 Quadrangle; also occurs in stocks to $5 \mathrm{~km}$ across in southeastern Mount Hayes C-3 Quadrangle.

\section{POST-ACCRETIONARY GRANITIC PLUTONIC ROCKS - NORTH OF DENALI FAULT}

An extensive suite of granitic plutonic rocks occurs in terranes north of Denali fault as small dikes, stocks, and a few large plutons. Many occurrences are too small to depict on the geologic map. The larger plutons are at Buchanan Creek and Molybdenum Ridge, west of Richardson Highway; Granite Mountain, east of Richardson Highway; and Macomb Plateau in east-central Mount Hayes Quadrangle. The granitic rocks are generally equigranular to porphyritic and medium grained and usually contain both hornblende and biotite. Alteration of feldspars to sericite slight; biotite locally altered to chlorite.

Locally in the Macomb Plateau area and in northeastern Mount Hayes Quadrangle, many Late Cretaceous (grma) granitic plutons exhibit weak to moderate schistosity with formation of lower greenschist-facies actinolite, chlorite, and white mica along the schistosity. Contact metamorphic aureole generally very narrow or lacking around older, Late Cretaceous granitic plutons; relation suggests intrusion during waning stages of regional metamorphism and penetrative deformation while the wall rocks were still warm (Nokleberg and others, 1989).

The isotopic ages for granitic plutons north of Denali fault are: (1) U-Pb zircon isotopic ages of about $90 \mathrm{Ma}$ (three determinations) (table 2 of Nokleberg and others [1992a], localities 3, 13, 19); (2) K-Ar hornblende and biotite ages of 84.0, 88.7, 88.8, 92.9, 93.3, and 103.6 Ma (table 2 of Nokleberg and others [1992a], localities 2, 13, 27, 35); and (3) Pb-Alpha ages of 90, 105, and $110 \mathrm{Ma}$ (two determinations), and $115 \mathrm{Ma}$ (table 2 of Nokleberg and others [1992a], localities 1, 5, 6, 8, 11). Excluding older and relatively less reliable $\mathrm{Pb}$-Alpha ages, these ages range from 84 to $105 \mathrm{Ma}$ and suggest intrusion of granitic plutons in mid to Late Cretaceous. The granitic plutons in the Macomb Plateau region in east-central Mount Hayes Quadrangle are isotopically dated only by Pb-Alpha studies and need additional study.

In eastern Mount Hayes Quadrangle southeast of Robertson River, Mount Gakona fault and Jarvis Creek Glacier and Hayes Glacier subterranes are intruded by the granite of Rumble Creek (grrc) K-Ar isotopic analysis of hornblende from this pluton yields an age of $88.7 \mathrm{Ma}$ (table 2 of Nokleberg and others [1992a], locality 27). If the K-Ar age represents the age of granitic intrusion, movement on Mount Gakona fault ceased by Late Cretaceous.

In the Windy terrane, a narrow, near-vertical granitic pluton exhibits K-Ar biotite and hornblende ages of 85.2, 85.9, 89.6, and 94.7 Ma (table 2 of Nokleberg and others [1992a], localities 39-41). These K-Ar values may be minimum ages for the pluton because of low-grade hydrothermal alteration and/or low-grade static metamorphism. A nearby granodiorite pluton to the northwest in Aurora Peak terrane may be of similar age.

grn1 GRANITIC UNIT 1 (early Tertiary and/or Late Cretaceous) — Granite dikes, stocks, and small plutons. Locally schistose. Fine to coarse grained. Hypautomorphic-granular and locally porphyritic with phenocrysts of plagioclase up to $5 \mathrm{~mm}$. Major minerals are quartz, plagioclase, K-feldspar, biotite, and hornblende. Local weak to intense hydrothermal alteration. Plagioclase partially recrystallized to sericite; biotite to chlorite plus epidote-clinozoisite. Local quartz and calcite veins.

Unit widely distributed in northern part of Mount Hayes Quadrangle. Mainly occurs in: (1) A thin, intermittently exposed, fault-bounded wedge approximately $1 \mathrm{~km}$ wide and $12 \mathrm{~km}$ long in fault contact with Aurora Peak terrane (as) to the northeast and Windy terrane (wm) to the southwest in northwestern Mount Hayes B-4 Quadrangle; (2) stocks up to $4.5 \mathrm{~km}$ across, intruding Pingston Terrane in northeastern Mount Hayes A-2 Quadrangle; (3) small bodies generally less than $1 \mathrm{~km}$ across; and (4) numerous dikes and sills rarely more than $1 \mathrm{~m}$ across.

grn2 GRANITIC UNIT 2 (early Tertiary and/or Late Cretaceous) - Granodiorite dikes, stocks, and small plutons. Fineto medium-grained, hypautomorphic-granular texture. Major minerals are plagioclase, quartz, K-feldspar, biotite 
and, locally, hornblende. Minor clinopyroxene and sphene present locally. Local sericite and chlorite alteration. Locally weak to strong schistosity exhibiting lower greenschist-facies metamorphism and/or hydrothermal alteration. Plagioclase partially recrystallized to sericite, epidote-clinozoisite, and calcite; mafic minerals to chlorite and epidote-clinozoisite.

Unit occurs in (1) A small stock approximately $2.5 \mathrm{~km}$ across intruding Aurora Peak terrane (as) along eastern Mount Hayes B-5/C-5 quadrangle boundary; and (2) plutons up to $6 \mathrm{~km}$ across intruding Macomb subterrane in northeastern Mount Hayes Quadrangle and southwestern Tanacross Quadrangle.

grn3 GRANITIC UNIT 3 (early Tertiary and/or Late Cretaceous)—Quartz diorite and diorite dikes, stocks, and small plutons. Fine- to medium-grained, hypautomorphic-granular texture. Major minerals are plagioclase, biotite and, locally, hornblende; quartz, white mica, and opaque minerals also present. Minor calcite, chlorite, and sericite alteration. Unit occurs in: (1) Scattered outcrops up to $5 \mathrm{~km}$ across in northeastern Mount Hayes B-2 and southeastern C-2 quadrangles; (2) dikes and sills up to $1 \mathrm{~m}$ wide in east-central Mount Hayes C-3 Quadrangle; and (3) small bodies less than $1 \mathrm{~km}$ across in northeastern Mount Hayes C-1 Quadrangle.

grn4 GRANITIC UNIT 4 (early Tertiary or Late Cretaceous) - Here and informally referred to as granite of Buchanan Creek. Chiefly biotite-hornblende granite with lesser granodiorite and quartz diorite. Fine- to medium-grained, hypautomorphic-granular texture. Major igneous minerals are quartz, K-feldspar, plagioclase, hornblende, and biotite. Locally altered, fractured, and granulated. Plagioclase partially recrystallized to sericite; hornblende and biotite to chlorite.

Unit exposed in an area approximately $15 \mathrm{~km}$ across in southwestern Mount Hayes D-1 Quadrangle and extends southward and westward into Mount Hayes C-6 Quadrangle. Intrudes and contains inclusions of fine-grained, schistose metavolcanic rocks and metasedimentary rocks (jcv) of Jarvis Creek Glacier subterrane; locally intruded by andesite and granite dikes up to $1 \mathrm{~m}$ wide.

A Late Cretaceous or early Tertiary age inferred from intrusion into rocks of Jarvis Creek Glacier subterrane subsequent to the main phase of Early to mid Cretaceous metamorphism. Slight deformation and sericite and chlorite alteration most likely occurred during waning stages of metamorphism.

grn5 GRANITIC UNIT 5 (early Tertiary or Late Cretaceous) - Mainly biotite granite. Fine- to medium-grained, hypautomorphic-granular texture. Major minerals are quartz, plagioclase, K-feldspar, biotite, and minor sphene. Locally altered; plagioclase and K-feldspar partially replaced by sericite. Unit exposed in an area approximately $10 \mathrm{~km}$ across in west-central Mount Hayes C-6 Quadrangle. Intrudes fine-grained schistose sedimentary rocks and volcanic rocks of Pingston Terrane. A Late Cretaceous or early Tertiary age indicated by intrusion into Hayes Glacier subterrane subsequent to Early to mid Cretaceous metamorphism. Informally referred to as granite of Mount Hayes.

grn6 GRANITIC UNIT 6 (Late Cretaceous) - Predominantly biotite-hornblende granodiorite with lesser granite and quartz diorite. Local inclusions of fine-grained metasedimentary rocks (jcs) of Jarvis Creek Glacier subterrane. Medium-grained, hypautomorphic-granular texture, locally porphyritic with phenocrysts of plagioclase to $4 \mathrm{~mm}$. Major minerals are plagioclase, K-feldspar, quartz, hornblende, and biotite. Hornblende locally replaced by igneous biotite. Weak local schistosity near contact with unit jcs. Locally fractured and granulated. Local hydrothermal alteration with hornblende and biotite partially replaced by chlorite, and plagioclase by white mica. Unit exposed in an irregular body approximately $9 \mathrm{~km}$ across. Intrudes and locally faulted against fine-grained metasedimentary rocks (jcs) of Jarvis Creek Glacier subterrane; intruded by granite, rhyolite, dacite, and andesite dikes approximately $1 \mathrm{~m}$ wide. A Late Cretaceous age of intrusion indicated from K-Ar biotite and hornblende dates, and U-Pb zircon ages ranging from 84 to $93 \mathrm{Ma}$ (table 2 of Nokleberg and others [1992a], locality 13). Informally referred to as granite of Molybdenum Ridge.

grn7 GRANITIC UNIT 7 (Late Cretaceous) - Chiefly biotite-hornblende granite; includes minor quartz diorite. Fine- to medium-grained, hypautomorphic-granular texture. Major minerals are quartz, plagioclase, K-feldspar, biotite, and hornblende. Minor minerals are white mica, apatite, sphene, calcite, chlorite, epidote, and opaque minerals. Local hydrothermal alteration; hornblende and biotite partially replaced by chlorite and opaque minerals, and plagioclase by white mica.

Unit forms large, well exposed pluton of approximately $160 \mathrm{~km}^{2}$ in Mount Hayes C-3, C-4, D-3, and D-4 quadrangles. Bounded by Granite Mountain fault to the northeast and northwest, and by Donnelly Dome fault to the southwest. Intrudes fine-grained metasedimentary rocks unit (jcs) of Jarvis Creek Glacier subterrane to the southeast. Contains 
small, isolated bodies of unit jes. Intruded by quartz diorite and aplite dikes up to $1 \mathrm{~m}$ wide and by a small gabbro stock west of Panoramic Peak in Mount Hayes D-3 Quadrangle. Late Cretaceous age of intrusion indicated from a single U-Pb zircon date of $90 \mathrm{Ma}$ (table 2 of Nokleberg and others [1992a], locality 19). Informally referred to as granite of Granite Mountain.

grn8 GRANITIC UNIT 8 (early Tertiary) -Mainly biotite granite; includes minor quartz diorite. Fine- to medium-grained, hypautomorphic-granular texture. Locally porphyritic with phenocrysts of K-feldspar up to $8 \mathrm{~mm}$. K-feldspar locally poikilitic with inclusions of quartz, plagioclase, and biotite. Major minerals are plagioclase, K-feldspar, quartz, biotite and, locally, hornblende. Minor minerals are clinopyroxene, sphene, and opaque minerals. Clinopyroxene partially replaced by igneous hornblende; biotite partially replaces hornblende. Locally fractured and granulated. Local epidote, carbonate, and white mica hydrothermal alteration.

Unit occurs as: (1) A partial ring dike around; and (2) small plutons in the intrusive suite of the Mount Hajdukovich area. An early Tertiary(?) age indicated by K-Ar isotopic dates of 53.4 and $54.3 \mathrm{Ma}$ (table 2 of Nokleberg and others [1992a], localities 21, 24). Informally referred to as granite of Gerstle River.

grn9 GRANITIC UNIT 9 (Late Cretaceous) - Chiefly hornblende granite, biotite granite, hornblende-biotite granite, hornblende granodiorite, and minor quartz diorite. Very-fine- to medium-grained, hypautomorphic-granular texture. Locally porphyritic with phenocrysts of plagioclase and poikilitic K-feldspar up to $8 \mathrm{~mm}$. Poikilitic K-feldspar containing inclusions composed of plagioclase, quartz, and biotite. Major groundmass minerals are quartz, Kfeldspar (locally perthitic), plagioclase, biotite, local hornblende partially replaced by biotite and minor sphene, opaque minerals, and clinopyroxene. Quartz diorite exhibits sparse, local compositional layering of hornblende and biotite alternating with quartz and feldspar. Local schistosity defined by alignment of biotite. Local weak to intense planar fracturing, granulation, and alteration with local development of protomylonite with strong schistosity. Hornblende and biotite locally partially replaced by chlorite and minor epidote, plagioclase by sericite and minor calcite and epidote, and K-feldspar by sericite. Locally cut by veins of quartz and calcite.

Unit exposed in numerous outcrops up to $8 \mathrm{~km}$ across. Surrounded by glacial deposits, colluvium, and ice in Mount Hayes B-1, C-1, and C-2 quadrangles. Bounded to the north by Tanana River fault, to the west by Johnson Glacier fault, and to the south by West Fork and Elting Creek faults. Intrudes metamorphosed pelitic, calcareous, and quartz-feldspar sedimentary rocks (mas) of the Macomb subterrane; intruded by small dikes up to $1 \mathrm{~m}$ wide of gabbro, lamprophyre, aplite, and rhyolite. Cretaceous age of intrusion indicated by two Pb-Alpha zircon dates of 90 and $110 \mathrm{Ma}$ (table 2 of Nokleberg and others [1992a], localities 8, 11). Informally referred to as granite of Macomb Plateau.

grn10 GRANITIC UNIT 10 (Late Cretaceous)_Predominantly granite. Fine- to medium-grained, hypautomorphicgranular texture. Locally porphyritic with phenocrysts of plagioclase and K-feldspar. Major groundmass minerals are quartz, K-feldspar, plagioclase, biotite and, locally, hornblende. Minor sphene, chlorite, opaque minerals, and white mica. Local hydrothermal alteration. Hornblende and biotite partially replaced by chlorite, plagioclase by calcite and white mica.

Unit exposed in numerous outcrops up to $6 \mathrm{~km}$ across. Surrounded by glacial deposits, colluvium, and ice in northcentral Mount Hayes A-1 Quadrangle. Intrudes metamorphosed volcanic and pelitic sedimentary rocks (jcv) of the terrane, and metamorphosed volcanic and pelitic sedimentary rocks of Hayes Glacier subterrane. Local abundant mafic inclusions along southeast margin. Unit crosscuts Mount Gakona fault between Jarvis Creek Glacier subterrane to northeast and Hayes Glacier subterrane to southwest. Late Cretaceous age of intrusion indicated by a K-Ar hornblende age of $89 \mathrm{Ma}$ (table 2 of Nokleberg and others [1992a], locality 27). If the K-Ar age represents age of granitic intrusion, movement on Mount Gakona fault ceased by Late Cretaceous. Informally referred to as granite of Rumble Creek.

\section{POST-ACCRETIONARY MAFIC PLUTONIC ROCKS - NORTH OF DENALI FAULT}

A suite of mafic plutonic rocks occurs adjacent to Denali fault in the Windy terrane, and Hayes Glacier and Jarvis Creek Glacier subterranes of the Yukon-Tanana terrane. Mafic rocks occur as sills, dikes, and plutons of hornblende metagabbro and hornblende metadiorite. Dikes and sills generally up to a few meters wide and several hundred meters long; most too narrow to depict on the geologic map. Dikes and sills mainly fine to medium grained; generally sub-concordant to acutely discordant to intense younger schistosity and parallel compositional layering. Common major igneous minerals are hornblende, plagioclase, and minor clinopyroxene, biotite, and quartz. 
The mafic dikes and sills are strongly deformed along the younger schistosity, and are partly to totally metamorphosed to lower greenschist-facies minerals, mainly chlorite, actinolite, epidote, albite, and sericite. Field relations indicate the mafic dikes and sills are relatively older than Cretaceous granitic rocks, which locally crosscut and intrude the mafic dikes and sills. Because of generally intense, low-grade metamorphism, Ar-based isotopic analyses are unsuitable for determining the age of these mafic plutonic rocks. An attempt to separate zircons from a sample of metagabbro intruding the Windy terrane to the southeast in northwestern Nabesna Quadrangle yielded too few zircons for U-Pb isotopic analysis (Nokleberg and others, 1992a).

mgb GABBRO, DIORITE, METAGABBRO, METADIORITE, METADIABASE, AND AMPHIBOLITE (Triassic) Chiefly hornblende metagabbro and metadiabase and minor amphibolite. Variably metamorphosed to greenschist facies and locally schistose. Undifferentiated dikes, sills, and small plutons.

Metagabbro and metadiabase generally fine- to medium-grained, hypautomorphic-granular to diabasic; locally porphyritic. Phenocrysts are plagioclase, hornblende, biotite, and pyroxene up to $2 \mathrm{~mm}$. Major minerals are plagioclase, hornblende and, locally, biotite, with minor clinopyroxene, orthopyroxene, quartz, sphene, and opaque minerals. Hornblende and biotite partially replaced by chlorite and epidote, and plagioclase by sericite, calcite, and epidote.

Amphibolite is fine to medium grained; granoblastic to porphyroblastic containing hornblende porphyroblasts up to $2 \mathrm{~mm}$. Local relict hypautomorphic-granular texture. Common major minerals are hornblende and/or actinolite, and plagioclase and, locally, quartz, biotite, and clinopyroxene. Common minor minerals are chlorite, sphene, white mica, garnet, epidote, calcite, and opaque minerals, and less commonly K-feldspar, tremolite, and vesuvianite. Compositional layering defined by nematoblastic amphibole and biotite alternating with plagioclase and quartz. Hornblende locally replaced by biotite; hornblende, biotite, and garnet variably replaced by chlorite; plagioclase replaced by white mica.

Unit widely distributed adjacent to, and north of, Denali fault. Occurs in stocks and smaller bodies up to $3 \mathrm{~km}$ across, and in dikes and sills up to $6 \mathrm{~km}$ long and $400 \mathrm{~m}$ wide but generally not exceeding $1 \mathrm{~m}$ in width.

Dikes locally crosscut schistosity in Windy terrane and in southern Yukon-Tanana terrane that formed during Early to mid Cretaceous metamorphism. Dikes also exhibit locally intense lower greenschist-facies metamorphism.

A Late Triassic crystallization age of $225.8 \pm 0.7 \mathrm{Ma}$ (by TIMS U-Pb zircon analysis) was obtained for a suite of gabbro sills intruding the metasedimentary and metavolcanic rocks of Jarvis Creek Glacier subterrane in the Bonnifield mining district in northern Healy D-1 Quadrangle adjacent to and west of Mount Hayes Quadrangle (Dashevsky and others, 2003; Dusel-Bacon and others, 2006).

\section{TERRANES - NORTH OF DENALI FAULT (FROM NORTH TO SOUTH)}

\section{Yukon-Tanana terrane}

The southern Yukon-Tanana terrane is a major block of crystalline rocks north of Denali fault (Foster and others, 1987; Nokleberg and others, 1989). Subterranes of the Yukon-Tanana terrane are interpreted as comprising tectonically dismembered remnants of a Devonian and Mississippian continental-margin igneous arc (Aleinikoff, 1984; Aleinikoff and Nokleberg, 1983, 1984; Aleinikoff and others, 1984; Aleinikoff, 1985; Nokleberg and Aleinikoff, 1985; Nokleberg and others, 1989). The upper structural levels, Hayes Glacier and Jarvis Creek Glacier subterranes, are interpreted as upper levels of the arc, whereas the lower levels, Macomb and Lake George subterranes, are interpreted as deeper levels of the arc. The metasedimentary, metavolcanic, and metaigneous rocks of the southern Yukon-Tanana terrane are multiply metamorphosed and deformed.

The southern Yukon-Tanana terrane is exposed in a major west-northwest-trending regional antiform. Hayes Glacier, Jarvis Creek Glacier, and Macomb subterranes occur on the south limb of the antiform, whereas Lake George subterrane, exhibiting subhorizontal schistosity and compositional layering, occurs near the core of the antiform. Southward, the subterranes occur at successively higher structural levels on the south limb of the antiform; dips steepen progressively to the south, and are near-vertical along Denali fault.

The structural stacking of these subterranes is significant; stratigraphically higher-level metaigneous rocks occur in structurally higher-level subterranes. For example, metamorphosed deep-level plutonic rocks occur in Lake George subterrane (Nokleberg and Aleinikoff, 1985; Foster and others, 1987). This subterrane consists of mesozonal Devonian and Mississippian granitic plutons and Devonian and older wall rocks, now highly deformed and metamorphosed. Metamorphosed hypabyssal Devonian metagranitic rocks occur in the structurally higher Macomb subterrane (Nokleberg and Aleinikoff, 
1985). Shallow-level, submarine metavolcanic and interlayered metasedimentary rocks occur in the structurally highest Jarvis Creek Glacier and Hayes Glacier subterranes.

These stratigraphic and structural relations suggest that subterranes of the Yukon-Tanana terrane represent, from north to south, successively higher levels of a single, now highly metamorphosed and deformed Devonian submarine igneous arc (Nokleberg and Aleinikoff, 1985). Two hypotheses for the origin of the Yukon-Tanana terrane are presented by Nokleberg and Aleinikoff (1985): (1) An island arc containing a slice of continental crust, which contaminated later magmas; or (2) a submerged continental margin arc, with continental detritus being shed into a companion trench and subduction zone system. A modern-day analog for the island-arc origin is the New Zealand setting; the analog for the submerged continental-margin arc setting is the Aleutian Arc.

Our preferred interpretation is a submerged continental-margin arc (Nokleberg and others, 1989), and is supported by the following: (1) Common lead isotopic studies for feldspar in metaplutonic and metavolcanic rocks indicate a continental component of highly radiogenic lead derived from a continental source, and assimilation of approximately 2.3-Ga-old material (Aleinikoff and others, 1986; 1987); (2) common lead isotopic studies on sulfide samples from Kuroko-type massive sulfide deposits in metavolcanic rocks, and which also indicate a component of continental, highly radiogenic lead (LeHurray and others, 1985); (3) high initial Sr ratios for augen gneiss and granitic gneiss in Lake George subterrane, indicating incorporation of crustal material into the granitic magma protolith (Dusel-Bacon and Aleinikoff, 1985; Aleinikoff and others, 1986); and (4) abundant and widespread quartz-detritus-rich sedimentary protoliths containing relict detrital zircons exhibiting $\mathrm{U}-\mathrm{Pb}$ ages of 2.1 to $2.3 \mathrm{Ga}$ (Aleinikoff and others, 1986; 1987). Common lead isotopic data also indicate a unique origin for the Yukon-Tanana terrane with respect to adjacent units (Aleinikoff and others, 1986; 1987). These data and interpretations also indicate a unique origin for the Yukon-Tanana terrane compared to adjacent terranes (Jones and others, 1982; 1987).

A submerged continental-margin arc origin for the Yukon-Tanana terrane differs widely from modern-day igneous arcs, which are almost solely emergent. However, abundant continentally-derived sediments, and the strong component of continental lead indicate derivation from a major continental source. In addition, the delicate interlayering of metavolcanic and metasedimentary rocks, locally with thin stratiform massive sulfide deposits, indicates widespread submarine volcanism.

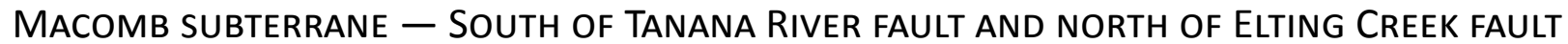

Macomb subterrane (Aleinikoff and Nokleberg, 1985; Nokleberg and Aleinikoff, 1985) occurs south of Lake George terrane in eastern Mount Hayes Quadrangle, and to the east in Tanacross Quadrangle, and is composed of: (1) A unit of older, polydeformed, medium-grained pelitic schist, calc-schist, and quartz-feldspar-biotite schist of Devonian or older age (ms) derived from shale, marl, and sandstone; and (2) a unit of relatively younger, shallow-level, fine- to medium-grained gneissose granite, granodiorite, quartz diorite, and diorite $(\mathrm{mg})$ of Devonian age. Both units ductilely deformed and regionally metamorphosed at epidote-amphibolite facies to upper greenschist facies into mylonitic schist (Nokleberg and others, 1986a). The subterrane differs from structurally subjacent Lake George subterrane to the north in possessing: (1) Relatively abundant Devonian hypabyssal metagranitic rocks; (2) abundant calcareous metasedimentary rocks; (3) a lower metamorphic grade; (4) a finer metamorphic grain size; and (5) a more intensely developed metamorphic fabric.

mag MEDIUM-GRAINED GRANITIC GNEISS (Devonian) - Chiefly fine- to medium-grained mylonitic gneiss derived from granite, granodiorite, and quartz diorite. Includes minor augen gneiss derived from granite to diorite. Textures vary from protomylonite to mylonitic schist. Relict hypautomorphic-granular texture. Porphyroclasts of plagioclase and local K-feldspar, up to $5 \mathrm{~mm}$ across, in a fine-grained, variably granulated and recrystallized matrix predominantly consisting of quartz, plagioclase, and locally K-feldspar, and minor schistose biotite and white mica. Relict igneous minerals include plagioclase, K-feldspar (locally perthite), biotite, local hornblende, and sphene. Common metamorphic minerals include biotite, white mica, chlorite, carbonate, garnet, hornblende, and opaque minerals, and less commonly, zoisite, staurolite, clinopyroxene, and allanite. Local poikiloblastic plagioclase includes variable amounts of biotite, epidote, quartz, sphene, garnet, and clinopyroxene. Biotite locally includes quartz and epidote and garnet locally includes epidote. Plagioclase partially replaced by sericite, calcite, and epidote; hornblende by chlorite and epidote; biotite by chlorite and hematite; garnet by biotite and chlorite. Local augen gneiss composed of fine-grained, quartzofeldspathic and biotite-hornblende-rich bands with augen, up to $2 \mathrm{~mm}$ long, of variably granulated quartz and feldspar.

Intensely deformed, exhibiting strong schistosity. Schistosity and parallel compositional layering dip moderately southwest and strike northwest, generally parallel to Elting Creek fault. Unit forms northwest-trending anticline with metamorphosed pelitic, calcareous, and quartz-feldspar sedimentary rocks (ms) of Macomb subterrane in Mount Hayes B-1 Quadrangle. Minor, small-scale, tightly appressed isoclinal folds occur in outcrop and thin section scale. Younger asymmetrical folds generally south- or southeast-verging; formed in older schistosity and compositional layering. Irregular contacts and locally abundant dikes indicate shallow intrusion. 
Unit metamorphosed at epidote-amphibolite to local amphibolite facies. Diagnostic epidote-amphibolite facies minerals are epidote-clinozoisite, biotite, and garnet. Diagnostic amphibolite facies minerals are staurolite and clinopyroxene. Local retrogressive metamorphism to lower greenschist facies indicated by replacement of biotite, hornblende, and garnet by chlorite. Unit occurs in Mount Hayes B-1 Quadrangle in several stocks up to $6 \mathrm{~km}$ across, northeast of Elting Creek fault. Intrudes unit of metamorphosed pelitic, calcareous, and quartz-feldspar sedimentary rocks (ms).

$\mathrm{U}-\mathrm{Pb}$ zircon isotopic analyses of samples of metagranodiorite and metagranite yield isotopic ages of about $372 \mathrm{Ma}$ (table 2 of Nokleberg and others [1992a], localities 7, 10), and indicate intrusion in the Devonian. A Rb-Sr mineral isochron isotopic analysis of metagranodiorite with a U-Pb zircon age of $372 \mathrm{Ma}$ indicates regional metamorphism and penetrative deformation of schistose minerals in this rock at $102 \mathrm{Ma}$ (table 2 of Nokleberg and others [1992a], locality 10; Nokleberg and others, 1986a).

mas

METAMORPHOSED PELITIC, CALCAREOUS, AND QUARTZ-FELDSPAR SEDIMENTARY ROCKS (Devonian or older) - Chiefly fine-grained, mylonitic, metasedimentary schists. Predominantly quartz-mica schist with lesser calc-schist. Protoliths mainly sandstone, siltstone, and marl. Estimated structural thickness of a few thousand meters.

Quartz-mica schists consist of garnet-bearing quartz-white mica schist, garnet-bearing quartz-biotite-white mica schist, quartz-biotite schist, quartz-plagioclase-biotite-andalusite-white mica schist, quartz-white mica-biotiteandalusite-cordierite-sillimanite schist, and minor quartzite. Minor minerals are graphite, chlorite, epidote, calcite, K-feldspar, tourmaline, apatite, zircon; rare hornblende and staurolite. Generally consists of fine-grained schistose mica in granular quartz. Local compositional layering parallels schistosity. Garnet porphyroblasts up to $8 \mathrm{~mm}$ across, averaging 1-2 $\mathrm{mm}$, and plagioclase porphyroblasts up to $2 \mathrm{~mm}$. Local helicitic garnet contains biotite, quartz, carbonate, and epidote inclusions. Andalusite poikiloblasts include biotite, and myrmekitic intergrowths in andalusite-sillimanite-bearing schist. Quartzite includes sparse, schistose mica, plagioclase, hematite, and opaque minerals. Local older schistosity oriented 45-60 degrees from more prominent younger schistosity. Weak to locally intense granulation and fracturing of quartz and feldspar. Plagioclase partially replaced by sericite and calcite; biotite by chlorite; garnet by chlorite, biotite, and white mica; andalusite by white mica.

Calc-schists consist of fine-grained tremolite-quartz-clinozoisite schist and quartz-calcite schist. Tremolite-quartzclinozoisite schist contains dimensionally aligned tremolite in granular quartz and clinozoisite. Minor minerals are chlorite, sphene, biotite, clinopyroxene, and opaque minerals. Quartz-calcite schist composed of crude to well defined layers of granular quartz, calcite, and locally epidote-clinozoisite.

Unit intensely deformed; exhibits strong schistosity. Schistosity and parallel compositional layering dip moderately southwest and strike northwest, generally parallel to Elting Creek fault. In Mount Hayes B-1 Quadrangle, this unit forms the southwest limb of a northwest-trending anticline. Minor small-scale, tightly appressed to isoclinal folds occur in outcrop and thin section scale. Younger asymmetrical folds mainly south- or southeast-verging; formed in older schistosity and compositional layering.

Unit metamorphosed mainly at epidote-amphibolite facies and, locally, to amphibolite facies. Diagnostic epidoteamphibolite facies minerals are epidote-clinozoisite, biotite, garnet, andalusite, cordierite, and staurolite. Diagnostic local amphibolite-facies minerals are hornblende, sillimanite, and clinopyroxene. Local retrogressive metamorphism to lower greenschist facies indicated by replacement of biotite by chlorite; garnet by chlorite and white mica; and andalusite by white mica.

Unit occurs in Mount Hayes B-1, B-2, and C-2 quadrangles. Bounded by Jarvis Creek subterrane to the southwest along Elting Creek fault and to the west along Johnson Glacier fault. Intruded by medium-grained granitic gneiss (mg), and by non-metamorphosed granitic rocks of Macomb Plateau pluton (grma). Age of the protolith is older than Devonian metagranitic rocks.

\section{Jarvis Creek Glacier subterrane - South of Elting Creek fault and north of Hines Creek AND MOUNT GAKONA FAULTS}

Jarvis Creek Glacier subterrane (Aleinikoff and Nokleberg, 1985; Nokleberg and Aleinikoff, 1985) occurs across northern Mount Hayes Quadrangle, south of Macomb subterrane. Jarvis Creek Glacier subterrane consists of fine-grained, polydeformed schists derived from Devonian metavolcanic and metagranitic rocks and Devonian and older sedimentary rocks. The subterrane differs from structurally subjacent Macomb subterrane to the north in possessing: (1) Relatively few Devonian metagranitic rocks; (2) abundant Devonian metavolcanic rocks; (3) a lower metamorphic grade; (4) a finer metamorphic grain size; and (5) a more intensely developed metamorphic fabric. 
This subterrane is subdivided into three units: (1) A metasedimentary rocks unit (jcs) composed chiefly of fine-grained metasedimentary rocks and very minor metavolcanic rocks; (2) a metavolcanic rocks unit (jcv) composed chiefly of finegrained metavolcanic rocks and moderate amounts of fine-grained metasedimentary rocks; and (3) a small unit of gneissose granodiorite and diorite and subordinate augen gneiss (jcg) in north-central Mount Hayes Quadrangle.

The metasedimentary and metavolcanic rocks are almost totally recrystallized and are composed of varying proportions of pelitic schist, quartzite, calc-schist, quartz-feldspar schist, and marble. Protoliths of shale, quartz sandstone, marl, sandstone, volcanic graywacke, and limestone. The metavolcanic rocks consist of varying proportions of abundant meta-andesite and metamorphosed quartz keratophyre, less abundant metadacite and metabasalt, and very minor metarhyodacite.

The metasedimentary rock and metavolcanic rock units are ductilely deformed and regionally metamorphosed at greenschist facies into mylonitic schist or, locally, phyllonite (Nokleberg and others, 1986a). Locally, large areas of upper greenschistfacies and lower amphibolite-facies metamorphism occur in the northern part of the Jarvis Creek Glacier subterrane in the area south of Granite Mountain and southeast of Donnelly Dome. The higher-grade metamorphic minerals to the north are progressively replaced by lower-grade metamorphic minerals to the south.

jcg FINE- TO MEDIUM-GRAINED GNEISSOSE GRANITIC ROCKS (Devonian)—Chiefly schistose metagranodiorite, and augen gneiss derived from granite. Intensely deformed exhibiting strong schistosity.

Metagranodiorite contains K-feldspar augen and relict phenocrysts up to $2.0 \mathrm{~cm}$ across in a fine-grained matrix of schistose biotite and granular and fractured quartz, K-feldspar, plagioclase, hornblende, and opaque minerals. Hornblende largely replaced by biotite and chlorite. Biotite partially replaced by chlorite; plagioclase by white mica and minor epidote.

Augen gneiss contains K-feldspar augen and relict phenocrysts up to $1.5 \mathrm{~cm}$ in a fine-grained matrix of schistose biotite with granular and fractured quartz, K-feldspar, plagioclase, hornblende, and opaque minerals. Variably developed segregations of quartz, feldspar, and biotite. Plagioclase and K-feldspar partially replaced by white mica and minor epidote and calcite. Hornblende and biotite partially replaced by chlorite. Variably metamorphosed at lower amphibolite to lower greenschist facies. Diagnostic metamorphic minerals are hornblende in amphibolite facies rocks and chlorite and epidote in lower greenschist-facies rocks.

Unit mainly underlies Donnelly Dome in southern Mount Hayes D-4 Quadrangle. Also occurs in several stocks up to $5 \mathrm{~km}$ across south of the Donnelly Dome fault in the southern Mount Hayes D-4 and northern C-4 quadrangles. Unit intrudes fine-grained metasedimentary rocks (jcs) and fine-grained schistose metavolcanic rocks and metasedimentary rocks (jcv).

$\mathrm{U}-\mathrm{Pb}$ zircon isotopic analysis of a sample of a small body of augen gneiss intruding unit jev in the area southeast of Donnelly Dome yields an age of 372 Ma (table 2 of Nokleberg and others [1992a], locality 17), and indicates intrusion in the Devonian, contemporaneously with extrusion of the metavolcanic rocks.

jev FINE-GRAINED SCHISTOSE METAVOLCANIC ROCKS AND METASEDIMENTARY ROCKS (Devonian) Chiefly fine-grained, mylonitic, metavolcanic rocks interlayered with lesser metasedimentary rocks. Metavolcanic rocks consist chiefly of metamorphosed quartz keratophyre, metadacite, and meta-andesite with lesser metarhyodacite and metabasalt derived from fine-grained tuffs and flows. Metasedimentary rocks chiefly quartz-mica schists and some calc-schists, marble, skarn, and quartzite. Protoliths for metasedimentary rocks mainly pelite, quartz sandstone, siltstone, marl, and limestone. Metavolcanic rocks occur in layers from about 0.5 to a few meters thick; interlayered with thin-to-thick layers of metasedimentary rocks. Estimated structural thickness of a few thousand meters.

Unit metamorphosed from lower greenschist to lower amphibolite facies. Differentiated from adjacent schists of Hayes Glacier subterrane to the south by a greater abundance of metavolcanic rocks, much sparser graphite-rich metasedimentary rocks, a coarser metamorphic mineral grain size, and a higher grade of metamorphism.

Metavolcanic rocks generally characterized by relict microporphyritic texture containing euhedral to subhedral, twinned, and often zoned plagioclase phenocrysts up to $4 \mathrm{~mm}$ long in a fine-grained groundmass of quartz, plagioclase, and schistose mica. Common poikilitic and clean, relict plagioclase phenocrysts. Relict quartz and K-feldspar phenocrysts occur locally. Local resorbed outlines of quartz and feldspar phenocrysts. Common metamorphic minerals are quartz, plagioclase, white mica, chlorite, epidote-clinozoisite, calcite, and opaque minerals. Sparse metabasalts composed mainly of actinolite and, locally, epidote and calcite. Minor metamorphic minerals are sericite, chlorite, sphene, biotite, garnet, hornblende, and opaque minerals. Compositional layering parallels schistosity; defined by bands and lenses of granoblastic quartz and feldspar alternating with schistose mica. Fracturing and granulation of relict phenocrysts common with development of augen and augen-shaped aggregates of quartz and 
feldspar in finer-grained recrystallized matrix. Plagioclase and K-feldspar partially replaced by sericite; biotite, actinolite, and hornblende by chlorite.

Quartz-mica schists consist of quartz-white mica schist, graphite-quartz-white mica schist, quartz-plagioclase-white mica-chlorite schist, quartz-white mica-chlorite-plagioclase schist, and calcite-chlorite-quartz schist. Minor minerals are calcite, plagioclase, chlorite, graphite, and other opaque minerals, and sparse garnet, hornblende, apatite, sphene, cordierite, zircon, and tourmaline. Generally fine grained. Sparse porphyroclasts of quartz and feldspar to $2 \mathrm{~mm}$. Sparse local, relict clastic grains of quartz and feldspar. Compositional layering parallels schistosity; generally defined by layers of granoblastic quartz and feldspar alternating with micaceous layers. Variably distorted, fractured, and granulated quartz and feldspar form augen or augen-shaped aggregates that accompany bent mica. Plagioclase partially replaced by white mica and calcite; biotite by chlorite.

Calc-schists and marbles consist of quartz-white mica-calcite schist, quartz-calcite schist, quartz-plagioclase-white mica-calcite schist, quartz-epidote-clinozoisite schist, quartz-white mica-epidote schist, epidote-plagioclase-actinolite schist, hornblende-biotite-calcite schist, hornblende-plagioclase-calcite schist, marble, and biotite marble. Minor minerals are K-feldspar, biotite, graphite, and opaque minerals. Skarns composed of variable proportions of major epidote, garnet, chlorite, calcite and, locally, clinopyroxene, actinolite, and wollastonite. Calc-schists and marbles generally fine grained with sparse porphyroclasts of quartz and plagioclase to $6 \mathrm{~mm}$. Compositional layering generally defined by granoblastic layers of quartz and/or plagioclase alternating with calcite and combinations of schistose mica, epidote-clinozoisite, amphibole, and opaque minerals. Quartz and calcite grains locally elongate parallel to schistosity and compositional layering. Plagioclase partially replaced by sericite and calcite; hornblende, actinolite, and biotite by chlorite.

Quartzites generally composed of sparse flakes to stringers and bands of schistose white mica and/or biotite and chlorite in fine-grained granoblastic quartz. Common weak to strong alignment of elongate quartz grains parallel to schistosity. Calcite occurs locally as porphyroclasts and in bands and patches. Common local fracturing and granulation. Minor minerals are graphite, plagioclase, K-feldspar, and opaque minerals.

Unit intensely deformed; exhibits strong schistosity. Schistosity and parallel compositional layering dips gently to moderately north or south, locally defining broad antiforms and synforms. In outcrop and thin section, compositional layering and schistosity are generally folded into moderately appressed to tight isoclinal folds with axial planes parallel to schistosity. Unit occurs mainly structurally above fine-grained metasedimentary rocks (jcs). Folds are formed in an older schistosity and subparallel compositional layering. Later folds are generally asymmetrical with south to southwest vergence and are superposed on older, more tightly appressed folds. In eastern Mount Hayes Quadrangle, unit is cut by left-lateral, northeast-trending West Fork and Robertson River faults. Ductile deformation adjacent to major faults has formed locally abundant phyllonites and blastomylonites.

Unit variably metamorphosed from lower amphibolite to lower greenschist facies. Upper greenschist- to lower amphibolite-facies minerals are biotite, garnet, cordierite, and hornblende. Lower to middle greenschist-facies metamorphic minerals are actinolite, chlorite, graphite, white mica, epidote-clinozoisite, and calcite. Areal retrogressive metamorphism from lower amphibolite to lower greenschist facies indicated by successive replacement of hornblende and biotite by chlorite, and plagioclase by white mica from north to south.

Unit occurs in elongate northwest-trending wedge, approximately $50 \mathrm{~km}$ long and up to $5 \mathrm{~km}$ wide, principally between Trident Glacier fault to the northeast and Hines Creek fault to the southwest in western Mount Hayes Quadrangle. Also occurs along eastern quadrangle boundary in a block approximately $30 \mathrm{~km}$ across, bounded by West Fork fault to the northwest, Elting Creek fault to the northeast, and Mount Gakona fault to the southwest. In contact with the fine-grained metasedimentary rocks (jcs) of Jarvis Creek Glacier subterrane to the north, and with Hayes Glacier subterrane to the south. Intruded by granodiorite of Molybdenum Ridge (grmr) and by numerous smaller stocks, dikes, and sills from granitic to gabbroic composition.

$\mathrm{U}-\mathrm{Pb}$ zircon isotopic analysis of samples of metavolcanic rocks (jcv), locally interlayered with metasedimentary rocks, yield ages of 364, 372, and about $375 \mathrm{Ma}$ (table 2 of Nokleberg and others [1992a], localities 12, 15, 28), and are interpreted to indicate extrusion in the Devonian.

jcs FINE-GRAINED METASEDIMENTARY ROCKS (Devonian and older) - Chiefly fine-grained, mylonitic metasedimentary rocks. Unit composed of approximately 65 percent quartz-mica schist, 15 percent quartzite, and 5 percent each of chlorite-white mica schist, quartz-biotite schist, calc-schist, and marble. Protoliths of mainly pelite, quartz sandstone, graywacke, marl, and limestone. Intense deformation and recrystallization has obliterated most relict minerals and textures. Estimated structural thickness of a few thousand meters. 
Quartz-mica schists consist of (in descending order of abundance) quartz-white mica schist, quartz-white mica-chlorite schist, quartz-white mica-calcite schist, quartz-white mica-calcite-chlorite schist, quartz-white mica-garnet-chlorite schist, and garnet-white mica-quartz schist. Common minor minerals are epidote, garnet, $\mathrm{K}$-feldspar, graphite, and sphene; rare tourmaline and cordierite. Fine grained. Porphyroblasts chiefly of quartz, plagioclase, garnet, and K-feldspar, and average $1 \mathrm{~mm}$ across, rarely exceeding $3 \mathrm{~mm}$ across. Rare relict clastic quartz and plagioclase grains. Compositional layering generally parallel to schistosity; defined principally by alternating bands and lenses of schistose micas and granular quartz and feldspar. Variably distorted, fractured, and granulated quartz and plagioclase form augen or augen-shaped aggregates that accompany bent mica and local helicitic garnet. Local blastomylonites. Plagioclase and andalusite locally replaced by white mica, and biotite by chlorite.

Quartzite grain size averages approximately $1 \mathrm{~mm}$ with occasional porphyroclasts up to $2 \mathrm{~mm}$. No relict sedimentary textures. Common major minerals are quartz, biotite, white mica, calcite and minor plagioclase, K-feldspar, chlorite, opaque minerals, and epidote. Common minor minerals are opaque minerals, K-feldspar, calcite and white mica, and rare hornblende. Orientation of elongate quartz grains, lenses of calcite, and/or opaque minerals, and local crystallographic orientation of quartz parallels schistosity. Variable fracturing and granulation of mineral grains common. Plagioclase partially recrystallized to white mica and calcite.

Chlorite-white mica schists very fine to fine grained. Local plagioclase porphyroblasts up to $1 \mathrm{~mm}$. Locally occurring major minerals are quartz, epidote-clinozoisite, plagioclase, K-feldspar, with lesser calcite and opaque minerals. Minor minerals are biotite and garnet. Local compositional layering parallels schistosity; defined by bands of quartz alternating with white mica and chlorite.

Quartz-biotite schists, mainly fine grained. Plagioclase porphyroblasts up to $1.5 \mathrm{~mm}$. Local major minerals are plagioclase, chlorite, K-feldspar, and epidote, and minor white mica, garnet, calcite, sphene, and garnet. Compositional layering parallels schistosity; defined by alternating bands of biotite and chlorite or white mica with bands of quartz and plagioclase. Helicitic garnet occurs locally. Biotite partially recrystallized to chlorite; garnet to biotite and chlorite.

Calc-schists and marbles consist of calcite-chlorite schist, plagioclase-quartz-epidote schist, marble, and quartzrich marble. Minor minerals are white mica, graphite, opaque minerals, and garnet. Fine grained. Porphyroblasts principally of quartz, plagioclase, and garnet up to $5 \mathrm{~mm}$ and average approximately $1 \mathrm{~mm}$. Rare relict clastic quartz grains. In calc-schists, compositional layering parallels schistosity; generally defined by alternating quartz and/or chlorite with variable combinations of plagioclase, calcite, or epidote. Compositional layering in marbles defined by calcite alternating with quartz-rich, and/or chlorite-rich layers. Common fracturing and granulation of mineral grains. Plagioclase locally replaced by white mica and calcite; garnet by chlorite.

Unit intensely deformed; exhibits strong schistosity. Schistosity and parallel compositional layering dip gently to moderately north or south, locally defining broad antiforms and synforms. Unit occurs mainly structurally beneath fine-grained, schistose metavolcanic rocks and metasedimentary rocks (jcv). Broad, major antiform occurs in Mount Hayes B-2, B-3, and B-4 quadrangles, subparallel to Denali fault. Major companion synform occurs to north in Mount Hayes C-3 and C-4 quadrangles, and trends east-west. Toward the south, near Hines Creek and Denali faults, schistosity and compositional layering dip moderately to steeply south and strike west-northwest parallel to the faults. In outcrop and thin section, compositional layering and schistosity generally folded into moderately appressed to tight isoclinal folds with axial planes parallel to schistosity. Folds formed in an older schistosity and compositional layering rather than bedding. Minor folds generally asymmetrical with south or southwest vergence. In central and eastern Mount Hayes Quadrangle, unit cut by the left-lateral, northeast-trending Johnson Glacier, West Fork, and Robertson River faults. Ductile deformation has formed locally abundant phyllonites and blastomylonites adjacent to major faults.

Unit metamorphosed from local lower amphibolite facies to lower greenschist facies. Diagnostic lower to middle greenschist-facies metamorphic minerals are actinolite, chlorite, white mica, epidote-clinozoisite, and calcite. Diagnostic upper greenschist- to lower amphibolite-facies minerals are biotite, garnet, andalusite, cordierite, and hornblende. Areal retrogressive metamorphism ranges from lower amphibolite facies in the north to lower greenschist facies to the south; defined by successive replacement of hornblende, biotite, and garnet to chlorite, and plagioclase to white mica.

Unit well exposed north of Denali fault, particularly in Mount Hayes B-1 to B-6 and C-2 to C-4 quadrangles. Faulted against Hayes Glacier subterrane along Mount Gakona fault in central and eastern Mount Hayes Quadrangle. Faulted against Aurora Peak terrane along Hines Creek fault in Mount Hayes B-4 and B-5 quadrangles, 
and against Wrangellia terrane along Denali fault in Mount Hayes B-4 Quadrangle. Intruded, from west to east, by granite of Buchanan Creek (grn4), granodiorite of Molybdenum Ridge (grn6), granite of Granite Mountain (grn7), granite of Gerstle River (grn8), granite of Macomb Plateau (grn9), granite of Rumble Creek (grn10), and by numerous dikes, sills, and small plutons ranging from granitic to gabbroic in composition.

On strike to the west in Healy Quadrangle metasedimentary rocks correlated with fine-grained metasedimentary rocks (jcs) of Jarvis Creek Glacier subterrane contain Devonian to Mississippian conodonts (Sherwood and Craddock, 1979; Csejtey and others, 1992). U-Pb isotopic analysis of clastic zircons in quartzites in unit jcs indicates the protolith was derived in part from an early Proterozoic source rock with radiometric sample ages of 2.0 to 2.3 Ga (table 2 of Nokleberg and others [1992a], localities 22, 23) (Aleinikoff and Nokleberg, 1985; Aleinikoff and others, 1987).

Isotopic analyses of schistose minerals in units jcs and jev indicate that regional metamorphism and associated penetrative deformation occurred in Early to mid Cretaceous. K-Ar isotopic analysis of white mica yields isotopic ages of 106, 107, 115, and $118 \mathrm{Ma}$ (table 2 of Nokleberg and others [1992a], localities 14, 16, 18, 20). Isotopic ages interpreted as the age of metamorphism, rather than the age of later cooling, because higher-temperature isotopic systems for higher-grade rocks, in deepest structural levels of Yukon-Tanana terrane to the north, yield the same Early to mid Cretaceous ages (Nokleberg and others, 1989).

\section{Pingston terrane - South of Hines Creek fault and north of Nenana Glacier and Denali faults}

Pingston terrane (former Hayes Glacier subterrane of Nokleberg and others, 1992b) occurs across west-central Mount Hayes Quadrangle and extends westward into northwestern and north-central Healy Quadrangle. In Mount Hayes Quadrangle, the terrane is bounded to the north by Jarvis Creek Glacier subterrane along Hines Creek fault, and to the south by Aurora Peak terrane along Nenana Glacier fault. Because of post-1992 analysis, this unit is now identified as a unique, fault-bounded terrane with a stratigraphy and structure that is highly distinct from structurally adjacent Jarvis Creek Glacier subterrane of Yukon-Tanana terrane to the north and Aurora Peak terrane to the south (Nokleberg and others, 1983; 1992b).

Pingston terrane consists chiefly of highly deformed and structurally interleaved lenses and blocks of metasedimentary and metavolcanic rocks. Large portions of units form a structural mélange with local blastomylonite and mylonite that occur in structurally interleaved lenses and blocks that also contain abundant brittle shears (microfaults). Stratigraphic relations are mostly obscured by intense deformation with local random interleaving of stratigraphic units.

Because of intense deformation, the terrane can only be divided into the following five major units: (1) Gabbro with lesser diabase (Cretaceous[?]); (2) limestone, calcareous sandstone, and phyllite (Triassic); (3) metabasalt (Paleozoic or Mesozoic[?]); (4) metasedimentary rock, chiefly phyllite and phyllonite with lesser chert and intermediate to siliceous metavolcanic rock (Silurian to Devonian); and (5) mafic to siliceous metavolcanic rock with lesser phyllite, metasiltstone, and chert (Devonian, Pennsylvanian, and Triassic). The terrane differs from Jarvis Creek Glacier subterrane of Yukon-Tanana terrane to the north in possessing: (1) No metagranitic rocks; (2) a greater abundance of graphitic-rich metasedimentary rocks and fewer metavolcanic rocks; (3) a lower metamorphic grade; (4) a finer metamorphic grain size; and (5) a locally intenselydeveloped, low-grade metamorphic fabric with abundant mylonitic textures.

The protolith of the terrane is interpreted as chiefly continental rise or slope sedimentary rock and associated submarine continental margin arc rock that were intruded by gabbro (Nokleberg and others, 1983; Nokleberg and Richter, 2007).

pimg GABBRO AND LESSER DIABASE (Cretaceous[?])—Fine- to medium-grained, hypidiomorphic granular texture. Two dominant lithologies occur: Plagioclase, clinopyroxene, and minor biotite; and plagioclase, biotite, local hornblende and minor quartz, and K-feldspar. Opaque minerals are locally abundant. Strongly zoned and twinned plagioclase phenocrysts to $1.8 \mathrm{~mm}$ occur locally. Clinopyroxene locally partially replaced by igneous biotite. Unit displays weak local alteration of biotite to chlorite, and plagioclase to sericite. Locally forms a large pluton that underlies McGinnis Peak and Mount Moffit in southwestern Mount Hayes C-5 Quadrangle, comprising an area approximately $6 \mathrm{~km}$ across.

pil LIMESTONE, CALCAREOUS SANDSTONE, AND PHYLLITE (Triassic) — Chiefly medium to thick beds of dark to light gray, medium- to coarse-grained limestone and local marble, medium gray, medium-grained calcite-quartz sandstone, and dark gray phyllite and phyllonite. Lithologies occur in highly deformed and structurally interleaved lenses and blocks in a random order. Local mylonite with extensive brittle shears (microfaults). West of the map area, in central Healy Quadrangle, this unit has yielded Triassic-age megafossils and conodonts (Sherwood and Craddock, 1979). 
pimb METABASALT (Triassic to Silurian) - Chiefly fine grained, amygdaloidal, and porphyritic. Unit is medium to dark greenish gray, and massive. Contains relict plagioclase phenocrysts up to $3 \mathrm{~mm}$ long, in a very-fine-grained, recrystallized groundmass of quartz, actinolite, and epidote. Locally contains amygdules filled with chlorite and epidote, and local calcite veins. Plagioclase is largely replaced by saussurite. Faint pillow structure occurs locally. Unit locally contains interbedded dark gray to black, generally fine-grained carbonaceous pelitic phyllite and phyllonite. Unit is more than $600 \mathrm{~m}$ thick. Occurs in fault-bounded lenses in units of Aurora Peak terrane in northwestern Mount Hayes B-4 Quadrangle.

pis METASEDIMENTARY ROCK, CHIEFLY PHYLLITE (Triassic to Silurian) - Chiefly fine-grained, pale yellow, pale green, and graphitic black metasedimentary phyllite and local extensive phyllonite and blastomylonite. Predominant lithologies are metachert, quartz-mica phyllite, quartz-calc-phyllite, quartzite, marble, and metavolcanic schist. Protoliths are siltstone, shale, marl, limestone, quartz-rich volcanic rocks, and volcanic graywacke. West of the map area, in central Healy Quadrangle, metasedimentary rocks have yielded Silurian and Devonian-age megafossils (Sherwood and Craddock, 1979).

Intense ductile deformation has obliterated most relict minerals and textures. Local relict meter-scale bedding occurs. Metamorphosed at lower to middle greenschist facies. Diagnostic lower greenschist-facies metamorphic minerals are white mica, chlorite, graphite, and calcite. Structural thickness of a few thousand meters is estimated for the unit.

Quartz-mica phyllite and phyllonite composed of subangular to subrounded quartz clasts in a fine-grained matrix of granular quartz and schistose white mica and, locally, biotite. Minor minerals are graphite, plagioclase, chlorite, calcite, hematite, opaque minerals, and rare andalusite. Unit contains local millimeter-scale, quartz-rich, mica-rich, and calcite-rich layers that parallel schistosity. Relict subrounded to subangular clastic quartz grains, up to $2 \mathrm{~mm}$. Local fine to coarse bands of graphite along schistosity.

Quartz-calc-phyllite and phyllonite composed mainly of sparse to abundant relict clasts of quartz and calcite up to $2 \mathrm{~mm}$ in matrix, very-fine-grained quartz, schistose sericite, feldspar, and abundant calcite. Locally contains thin, graphite-rich layers. Marble is granoblastic to schistose and locally contains minor quartz, white mica, and graphite.

Quartzite contains local quartz-mica phyllonite. Compositional layering defined by variably proportioned bands of quartz and white mica, and minor biotite, chlorite, and calcite.

Metavolcanic schist is composed mainly of relict phenocrysts of plagioclase and lesser quartz and K-feldspar, up to $3 \mathrm{~mm}$ long, variably fractured and granulated in a matrix of fine, granular quartz and schistose sericite. Minor minerals are calcite, chlorite, and opaque minerals. Resorbed outlines of quartz and plagioclase are locally preserved. Plagioclase is partially replaced by sericite.

Unit is intensely deformed and exhibits strong schistosity. Schistosity dips moderately to steeply south and strikes east-west to northwest, generally parallel to Denali and Hines Creek faults. Remnant small-scale isoclinal folds occur in outcrop and thin section with axial planes parallel to schistosity that deforms an older, less apparent schistosity. Most folds obliterated by intense deformation along younger schistosity.

Unit occurs in fault-bounded wedges, and is intruded by gabbro of Mount Moffit (pimg) and by smaller bodies, dikes, and sills of granite and gabbro.

piv MAFIC TO SILICEOUS METAVOLCANIC ROCK WITH LESSER PHYLLITE, METASILTSTONE, AND CHERT (Triassic to Silurian) - Chiefly fine-grained, metavolcanic rock and lesser metasedimentary phyllite and phyllonite. Major lithologies are metamorphosed quartz keratophyre and meta-andesite, and sparse metalatite, metarhyodacite, metadacite, and metabasalt. Structural thickness estimated to be a few thousand meters. West of the map area, in central Healy Quadrangle, metasedimentary rocks in this unit have yielded Pennsylvanian and Triassic megafossils (Sherwood and Craddock, 1979). A U-Pb zircon age from a metarhyodacite layer in the terrane is $375 \pm 8 \mathrm{Ma}$ (Aleinikoff and Nokleberg, 1983; Nokleberg and others, 1992a).

Metavolcanic rocks composed mainly of relict phenocrysts (up to $3.5 \mathrm{~mm}$ and averaging about $1.5 \mathrm{~mm}$ ) of quartz and plagioclase in a groundmass of very-fine-grained granular quartz, feldspar, abundant schistose chlorite, sericite, $\mathrm{K}$-feldspar, calcite, epidote, actinolite, and sparse biotite. Unit is locally intensely deformed into blastomylonite. Relict plagioclase phenocrysts occur and are commonly fractured and locally recrystallized to augen-shaped aggregates. Unit is intensely deformed into phyllonite. Plagioclase and K-feldspar are partially replaced by white mica; biotite by chlorite. 
Metasedimentary rocks are chiefly quartz-mica phyllite and phyllonite, quartzite, and quartz-calc phyllite and phyllonite. Protoliths for the metasedimentary rocks are siltstone, sandstone, graywacke, marl, and limestone.

Quartz-mica phyllite and phyllonite are predominantly quartz-white mica phyllonite with lesser quartz biotite phyllite and phyllonite, quartz-biotite-K-feldspar phyllite and phyllonite, and white mica-biotite-quartz-graphite phyllite and phyllonite. Common minor minerals are plagioclase, chlorite, calcite, epidote, hematite, andalusite, graphite, chlorite, and opaque minerals. Generally fine grained. Patches of calcite occur locally. Compositional layering, preferred orientation of elongate quartz grains, and grain-size segregation are parallel to schistosity. Compositional layering defined by layers of quartz alternating with layers of mica and, locally, layers of K-feldspar, graphite, and rare andalusite. Local relict rounded quartz pebbles. Unit locally exhibits intense granulation and fracturing of quartz and plagioclase. Plagioclase partially replaced by calcite and white mica. Biotite partially replaced by chlorite.

Unit intensely recrystallized and ductilely deformed. Metamorphosed at lower to middle greenschist facies with local metamorphic biotite. Schistosity dips moderately to steeply south and strikes east-west to northwest, generally parallel to Denali and Hines Creek faults. Remnant, small-scale, isoclinal folds with axial planes are parallel to schistosity, which deforms older schistosity. Most folds obliterated by intense deformation along younger schistosity.

Unit occurs in fault-bounded wedges and is intruded by metagabbro of Mount Moffit (pimg), and smaller gabbroic stocks, dikes, and sills. U-Pb zircon isotopic analysis of samples of metavolcanic rocks (piv) in eastern Mount Hayes Quadrangle, interlayered and metasedimentary rocks, yield an age of $375 \mathrm{Ma}$ (table 2 of Nokleberg and others [1992a], localities 32, 34, 36).

\section{Aurora Peak terrane - South of Nenana Glacier fault and north of Denali fault}

Aurora Peak terrane (Nokleberg and others, 1985; 1992b; Nokleberg and Richter, 2007) occurs north of Denali fault in western Mount Hayes Quadrangle. The terrane consists of: (1) A relatively older unit of metasedimentary rocks, chiefly fine- to medium-grained and polydeformed calc-schist, marble, quartzite, and pelitic schist (as); and (2) a relatively younger unit of regionally metamorphosed and penetratively deformed gneissic granitic rocks derived from quartz diorite, granodiorite, granite, gabbro, and diorite (ag). The protoliths for metasedimentary rocks are marl, quartzite, and shale. Aurora Peak terrane was twice ductilely metamorphosed and deformed, once into mylonitic schist during an earlier period of upper amphibolite facies metamorphism, and later into blastomylonite during a period of middle greenschist-facies metamorphism (Nokleberg and others, 1992b). The general parallelism of the schistosity in gneissic granitic rocks with Denali and Nenana Glacier faults suggests that metamorphism and deformation occurred while the faults were active.

Like Maclaren terrane to the south, Aurora Peak terrane is interpreted as a displaced fragment of Kluane schist and Ruby Range batholith that occurs northeast of Denali fault some $400 \mathrm{~km}$ to the southeast in Yukon Territory (Nokleberg and others, 1985; 1992b; Nokleberg and Richter, 2007). Although somewhat similar, Aurora Peak and Mclaren terranes are distinct terranes because of the presence of the structural mélange of sedimentary and volcanic rocks of the Paleozoic and Cretaceous Windy terrane between the two terranes.

ag METAMORPHOSED GRANITIC ROCK (early Tertiary to mid Cretaceous) — Consists chiefly of stocks, dikes, and sills of metadiorite and minor metamorphosed quartz diorite, granite, granodiorite, and gabbro. Metadiorite and metamorphosed quartz diorite composed of variable amounts of hornblende, clinopyroxene, quartz, and biotite and lesser orthopyroxene, quartz, calcite, sericite, clinozoisite, sphene, apatite, and hematite. Unit is fine to medium grained with relict hypidiomorphic granular texture. Hornblende and plagioclase are variably recrystallized. Hornblende rims clinopyroxene and opaque minerals. Plagioclase partially replaced by white mica.

Metagranite and metagranodiorite are fine to medium grained and are composed of variable amounts of biotite and white mica, and lesser chlorite, epidote, calcite, sericite, sphene, garnet, andalusite, and actinolite. Relict hypautomorphic-granular texture is present. Metagranodiorite locally contains relict K-feldspar phenocrysts to 7 $\mathrm{mm}$ across. Plagioclase and K-feldspar variably replaced by sericite and minor epidote; clinopyroxene by biotite and chlorite; biotite by chlorite.

Unit moderately deformed; exhibits moderate schistosity that dips steeply to vertical and strikes west-northwest. Variably fractured, deformed, and granulated, and is metamorphosed to amphibolite facies. Diagnostic amphibolite facies minerals are biotite, garnet, hornblende, and clinopyroxene. Local retrogressive metamorphism indicated by partial replacement of plagioclase and K-feldspar by sericite and epidote; clinopyroxene by biotite and chlorite; and biotite by chlorite. 
Unit occurs principally in southern Mount Hayes C-6 Quadrangle. Unit is faulted against Maclaren terrane to the south along Denali fault and against Pingston terrane to the north along Nenana Glacier fault. Unit intrudes metamorphosed sedimentary rocks (as) in stocks, dikes, and sills, and is intruded by slightly metamorphosed granite dikes approximately $1 \mathrm{~m}$ wide.

In the map area, $\mathrm{U}-\mathrm{Pb}$ zircon isotopic analysis of a metadiorite yields a Late Cretaceous age of $71 \mathrm{Ma}$ (table 2 of Nokleberg and others [1992a], locality 38). To the west in east-central Healy Quadrangle, ${ }^{40} \mathrm{Ar}^{39} \mathrm{Ar}$ isotopic analysis of hornblende in correlative (meta) granitic rocks yields a mid Cretaceous age of $106 \mathrm{Ma}$ (Csejtey and others [1992], locality 33). These isotopic ages are interpreted as mid Cretaceous to early Tertiary intrusion of metagranitic rocks in Aurora Peak terrane.

Isotopic analyses of schistose biotite and hornblende in metagranitic rocks are interpreted as forming during uplift and cooling of Aurora Peak terrane in the middle Tertiary. K-Ar isotopic analysis of biotite yields ages of 18.2, 24.0, and $27 \mathrm{Ma}$ (table 2 of Nokleberg and others [1992a], localities 37,38). K-Ar isotopic analysis of hornblende yields an age of $36.8 \mathrm{Ma}$ (table 2 of Nokleberg and others [1992a], locality 37). Because of older U-Pb zircon isotopic ages, and because Aurora Peak terrane occurs adjacent to Denali fault, these K-Ar isotopic dates are interpreted as ages of uplift and cooling of Aurora Peak terrane during Cenozoic migration along Denali fault (Nokleberg and others, 1985; 1989; 1992b).

amg METAGABBRO AND METADIORITE (Cretaceous[?]) — Chiefly fine-grained hornblende and plagioclase and minor biotite, clinopyroxene, calcite, chlorite, quartz, white mica, and sphene. Contains local compositional layering defined by alternating bands of schistose biotite and nematoblastic hornblende. Clinopyroxene partially replaced by hornblende and biotite; plagioclase by white mica.

HIGH-GRADE METASEDIMENTARY SCHIST AND CARBONATE (Triassic to Silurian) - Chiefly fine- to medium-grained mylonitic calc-schist, marble, quartz-mica schist, and quartzite. Protoliths are marl, limestone, pelite, and sandstone. Structural thickness is estimated at a few thousand meters.

Calc-schist predominantly consists of quartz-calcite schist grading to marble, but includes some chlorite-calcite schist, plagioclase-calcite schist, biotite-quartz-calcite-hornblende schist, and quartz-epidote-biotite-calcite schist. Minor minerals are white mica, K-feldspar, actinolite, wollastonite, tremolite, clinopyroxene, garnet, graphite, sphene, zoisite, and opaque minerals. Marble locally contains clinopyroxene and garnet. Compositional layering generally consists of alternating quartz and calcite-rich layers with lesser schistose mica. Quartz, plagioclase, and calcite are commonly elongate parallel to schistosity. Variably fractured, granulated, and recrystallized quartz and plagioclase porphyroclasts form augen and augen-shaped aggregates up to $1.5 \mathrm{~mm}$ in blastomylonites. Sparse relict clastic quartz grains occur locally. Plagioclase partially replaced by white mica and clinozoisite; clinopyroxene by actinolite and clinozoisite.

Quartz-mica schists consist of quartz-white mica schist, white mica-quartz schist, quartz-biotite schist, chloritewhite mica-quartz schist, and quartz-chlorite-white mica-graphite schist. Minor minerals are plagioclase, graphite, garnet, calcite, biotite, and opaque minerals. Displays compositional layering defined by alternating quartz-rich and mica-rich layers. Variably distorted, fractured, and granulated quartz and plagioclase commonly form elongate grains parallel to schistosity. Plagioclase is partially recrystallized to white mica.

Intensely ductilely deformed. Schistosity and parallel compositional layering dip steeply to vertically and strike west-northwest, parallel to Hines Creek fault, Nenana Glacier fault, and Denali fault. Unit is in Mount Hayes B-5 and C-5 quadrangles. Small isoclinal folds, defined by folding of an older schistosity, possess axial planes parallel to the dominant and younger schistosity. Local extreme ductile deformation occurs along schistosity and produces mylonitic schist and local blastomylonite.

Unit exhibits two periods of metamorphism: An older period at upper amphibolite facies, and a younger period at middle greenschist facies. Diagnostic upper amphibolite-facies minerals are hornblende, clinopyroxene, garnet, biotite, and wollastonite. Diagnostic middle greenschist-facies minerals are chlorite, epidote, biotite, white mica, actinolite, and biotite. Lower-grade rocks are present mainly along margins of the terrane near Denali, Nenana Glacier, and Hines Creek faults. Retrogressive metamorphism is indicated by partial replacement of clinopyroxene by actinolite and clinozoisite, plagioclase by white mica.

Unit occurs in a fault-bounded wedge, in west-central Mount Hayes Quadrangle, between Hines Creek fault to the northeast, Nenana Glacier fault to the north, and Denali fault to the south. Unit is intruded by stocks, dikes, and sills of metamorphosed and deformed diorite, granodiorite, and granite, and by stocks, dikes, and sills of weakly 
schistose and weakly metamorphosed gabbro. Intrusive contacts are locally faulted.

Age of the protolith of the metasedimentary rocks is constrained to Silurian through Triassic as determined from conodont fragments of post-Ordovician morphotype from one marble body (table 1 of Nokleberg and others [1992a], locality 7).

\section{Windy terrane - In splays of Denali fault}

Windy terrane (Jones and others, 1987; Nokleberg and others, 1985; 1992b; Nokleberg and Richter, 2007) occurs across south-central and southeast Mount Hayes Quadrangle and northwest Nabesna Quadrangle, in branches of Denali fault, north of Maclaren terrane, and south of Aurora Peak and Yukon-Tanana terranes. Unlike adjacent terranes to the north and the south, Windy terrane exhibits primary sedimentary or volcanic textures and structures. Relict sedimentary structures are bedding, graded bedding, and crossbedding. Windy terrane occurs in narrow slivers that are present discontinuously for several hundred kilometers along Denali fault (Jones and others, 1987; Nokleberg and Richter, 2007). Windy terrane consists of a structural mélange defined by interleaved, fault-bounded lenses.

Major units in Windy terrane are narrow, fault-bounded lenses of: (1) Cretaceous flysch consisting of one unit of phyllite and argillite, and minor metagraywacke and marl, and another unit of metagraywacke and lesser phyllite; (2) Cretaceous andesite, dacite, and volcanic graywacke; and (3) narrow, fault-bounded slivers (many too small to depict on map) of Silurian(?) and Devonian limestone and marl. Estimated structural thickness of the terrane is about 3,000-4,000 m.

Local intense schistosity strikes northwest parallel to branches of Denali fault and dips moderately to steeply northeast in western Mount Hayes Quadrangle and moderately southwest in eastern part of quadrangle. Local intense deformation occurs with development of phyllonite and protomylonite. Local abundant brittle shears (microfaults) and fault gouges are present along the southern margin of unit. Unit exhibits incipient greenschist-facies metamorphism. Diagnostic minerals are very-fine-grained chlorite, graphite, sericite, epidote, and actinolite.

The terrane is faulted against Jarvis Creek Glacier subterrane, and Pingston and Aurora Peak terranes north of Denali fault, and Wrangellia and Maclaren terranes south of Denali fault. The terrane is intruded by a weakly schistose granite pluton in Mount Hayes B-4 Quadrangle and by small granitic and gabbroic dikes and sills.

The Cretaceous flysch and associated volcanic rocks are interpreted as remnants of Kahiltna terrane and associated Gravina arc (Stanley and others, 1990; Nokleberg and Richter, 2007). The Silurian(?) and Devonian limestone and marl are interpreted as possibly derived from weakly metamorphosed parts of Yukon-Tanana terrane to the north. The terrane is a structural mélange of the two major units that have been tectonically mixed during Cenozoic dextral-slip movement along Denali fault (Nokleberg and others, 1989; Nokleberg and Richter, 2007).

The terrane contains one known fragment of a Cretaceous ammonite (table 1 of Nokleberg and others [1992a], locality 8) that was found in float, but interpreted as derived from the unit of flysch and volcanic rocks (J.H. Stout, written commun., 1976). Marl and limestone unit contains Silurian(?) and Devonian megafossils and microfossils (table 1 of Nokleberg and others [1992a], localities 8-11).

wm MÉLANGE (Cretaceous, Devonian, and Silurian[?])—Structural mélange consisting of two assemblages: (1) Fault-bounded lenses of Cretaceous flysch and volcanic rocks consisting mainly of argillite, and weakly metamorphosed quartz siltstone, quartz sandstone, metagraywacke, and metaconglomerate and minor andesite and dacite; and (2) small to large, fault-bounded lenses of Silurian(?) and Devonian limestone and marl. Locally mélange unit is subdivided into below-listed units (wgr, wp, and wa). Estimated structural thickness of about 3,000-4,000 m.

wgr PHYLLITE AND ARGILLITE AND MINOR METAGRAYWACKE AND MARL (Cretaceous) —Chiefly medium to dark gray, fine-grained phyllite and argillite with lesser medium-grained metagraywacke, marl, and sparse limestone.

Phyllite and argillite are composed of quartz grains, up to $0.2 \mathrm{~mm}$, in very-fine-grained matrix of quartz, chlorite, graphite, and sericite. Contains local plagioclase and quartz-rich silty layers, and minor hematite and opaque minerals. Sandy to pebbly siltstone composed of subangular quartz clasts in variable matrix of quartz and sericite, and minor calcite, biotite, epidote, actinolite, opaque minerals, and sphene also are present.

Local layers of metagraywacke composed of angular clasts of quartz, plagioclase, and locally K-feldspar, up to $0.4 \mathrm{~mm}$, in matrix of sparse, very-fine-grained quartz, white mica, and calcite. Plagioclase clasts locally twinned and zoned. Minor minerals are epidote, biotite, chlorite, sphene, and opaque minerals. Includes minor conglomerate composed of medium- to coarse-grained, angular fragments of argillite, silty argillite, chert, and metavolcanic graywacke in a matrix of very-fine-grained quartz and mica. Relict radiolaria in chert clasts. Sandstone composed of 
fine- to medium-grained, subangular grains of quartz in a fine-grained matrix predominantly of sericite. Plagioclase and K-feldspar partially replaced by white mica. Local sandy to pebbly siltstone composed of subangular quartz clasts in variable matrix of quartz and sericite, and minor calcite, biotite, epidote, actinolite, opaque minerals, and sphene. Marl is mainly black to light gray and well bedded. Exhibits sparse crossbedding and consists mainly of fine-grained, phyllitic white mica and calcite enclosing granular quartz and epidote. Major minerals are quartz, calcite, epidote, and white mica. Minor minerals are chlorite, graphite, sphene, tourmaline, and opaque minerals. Unit contains sparse relict angular quartz grains. Unit locally grades into calcareous sandstone. Locally contains sparse quartz pebbles.

Unit also contains local fine- to medium-grained, light to dark gray limestone composed mainly of calcite and minor dolomite. Locally, abundant corals, sparse grains of quartz, and variable amounts of graphite are present.

wp PHYLLITE AND LESSER ARGILLITE (Cretaceous)—Refer to description for unit wgr, above.

wa ANDESITE (Cretaceous) — Chiefly composed of phenocrysts of plagioclase, up to $1.0 \mathrm{~mm}$ long, and occasional quartz and biotite in groundmass composed predominantly of plagioclase and minor calcite, epidote, chlorite, white mica, and opaque minerals. Dacite composed of phenocrysts of quartz, plagioclase, and biotite up to $1.0 \mathrm{~mm}$ across in groundmass of plagioclase microlites with epidote, white mica, and opaque minerals. Relict fine-grained igneous textures. Plagioclase and K-feldspar partially replaced by white mica.

wl LIMESTONE (Silurian[?] and Devonian[?])—Chiefly limestone and lesser marl. Light to dark gray limestone composed mainly of calcite and minor dolomite. Fine to medium grained. Local abundant corals; local sparse grains of quartz and variable amounts of graphite. Includes marl mainly black to light gray, well bedded. Exhibits sparse crossbedding. Mainly fine-grained, phyllitic white mica and calcite enclosing granular quartz and epidote. Major minerals are quartz, calcite, epidote, and white mica. Minor minerals are chlorite, graphite, sphene, tourmaline, and opaque minerals. Sparse relict angular quartz grains. Grades into calcareous sandstone. Local sparse quartz pebbles.

Various units of Windy terrane occur in narrow, interleaved, fault-bounded lenses. Local intense schistosity strikes northwest parallel to branches of Denali fault and dips moderately to steeply northeast in central Mount Hayes Quadrangle and moderately southwest in eastern Mount Hayes Quadrangle. Local intense deformation and development of phyllonite and protomylonite. Local intense shearing and fault gouge along southern margin of unit. Incipient greenschist-facies metamorphism. Diagnostic minerals are very-fine-grained chlorite, graphite, sericite, epidote, and actinolite.

The Windy terrane occurs in three areas: (1) Eastern Mount Hayes A-1 Quadrangle, north of and adjacent to Denali fault; (2) across the Mount Hayes B-4/B-5 quadrangle boundary in branches of Denali fault; and (3) in northwestern Nabesna Quadrangle. In fault contact with Jarvis Creek Glacier and Hayes Glacier subterranes and Aurora Peak terrane north of Denali fault, and Wrangellia and Maclaren terranes south of Denali fault. Intruded by a weakly schistose granitic pluton (grn1) in Mount Hayes B-4 Quadrangle, and by small granitic and gabbroic dikes and sills.

The Windy terrane contains one known fragment of a Cretaceous ammonite (table 1 of Nokleberg and others [1992a], locality 8). The ammonite fragment was found in float, but interpreted as derived from the assemblage of flysch and volcanic rocks (J.H. Stout, written commun., 1976). Assemblage of limestone and marl contains Silurian(?) and Devonian megafossils and microfossils (table 1 of Nokleberg and others [1992a], localities 8-11). Marble on strike to southeast in Nabesna Quadrangle contains Middle Devonian rugose corals (Richter, 1976). Correlative unit of mélange of Windy terrane is on strike to the west in Healy Quadrangle (Jones and others, 1982; 1987; Csejtey and others, 1992). Mélange is divided into three sheared and intermixed units designated unit $\mathrm{m} 2$ (sandstone, argillite, and subordinate conglomerate), unit 12 (limestone), and unit um (serpentinized ultramafic rocks). Unit 12 yields Ordovician or Devonian mollusks, brachiopods, and conodonts, Devonian crinoids and corals, Middle Devonian corals and stromatoporoids, late Middle Devonian conodonts, and Late Triassic pelecypods and an ammonite(?). Unit $\mathrm{m} 2$ yields Mississippian and Jurassic radiolarians, and Late Jurassic to Late Cretaceous pelecypods.

\section{TERTIARY SEDMENTARY ROCKS - SOUTH OF DENALI FAULT}

Scattered outcrops of continental Tertiary sedimentary rocks occur south of Denali fault. The two main units are a conglomerate unit (Tc) and a sandstone and conglomerate unit (Tsc). The sandstone and conglomerate unit locally contains sparse volcanic ash and argillite, and the conglomerate unit locally contains sandstone and argillite. The stratigraphic succession of 
these units is best established along the southern flanks and to the southeast of Rainbow Mountain in south-central Mount Hayes Quadrangle. Elsewhere, these three sedimentary and volcanic rock units may laterally grade into one another.

Tsc SANDSTONE AND CONGLOMERATE (Miocene to Eocene) - Chiefly continental clastic deposits of lightcolored, fine-grained, poorly sorted sandstone consisting of locally interbedded siltstone, pebbly sandstone, pebble to cobble conglomerate, and sparse thin coal layers. Also contains very sparse white rhyodacite ash layers near The Hoodoos. Moderately well cemented, locally by hematite. Locally weathers orange-brown. Abundant crossbedding, ripple marks, and pebble imbrication. Locally crude bedded containing lenticular sandstone and conglomerate layers. Locally abundant organic debris including carbonized leaf impressions and tree trunks. Top eroded; base often faulted. Maximum exposed stratigraphic thickness of a few hundred meters.

Conglomerate clasts composed predominantly of andesite porphyry, fine-grained granitic rocks, schistose rocks, quartz, and locally abundant ultramafic rocks and coal. Sparse clasts of dark argillite contain late Paleozoic bryozoans and brachiopods derived from Eagle Creek Formation or upper part of Slana Spur Formation.

Common lithic fragments in sandstone of granite, schist, mafic, and ultramafic rocks. Common mineral grains of quartz and plagioclase; minor hornblende and clinopyroxene. Local chlorite, white mica, calcite, and epidote alteration. Interpreted as probable channel deposits laid down by braided streams on alluvial fans. Maximum exposed stratigraphic thickness of several hundred meters.

Unit occurs mainly in scattered exposures up to $4 \mathrm{~km}$ across, in Mount Hayes A-3, A-4, and southern B-4 and B-5 quadrangles. Unit both depositionally overlies, and is faulted against, Slana Spur Formation.

Age range of Eocene to Miocene. K-Ar isotopic analysis of hornblende from a white rhyodacite ash layer about one-half mile south of The Hoodoos yields an age of 5.5 Ma (Late Miocene) (table 2 of Nokleberg and others [1992a], locality 78). K-Ar isotopic analyses of hornblende from a rhyodacite tuff from a fault-bounded wedge of sandstone in southwestern Mount Hayes Quadrangle yields an age of 31.1 Ma (Oligocene) (table 2 of Nokleberg and others [1992a], locality 84). Several localities, mainly in south-central and southeastern Mount Hayes Quadrangle, yield plant and pollen fossils that range in age from late Eocene to Pliocene (table 1 of Nokleberg and others [1992a], localities 58, 64, 70, 75, 85).

Tc CONGLOMERATE (Eocene) - Chiefly continental clastic deposits composed of poorly sorted, crudely bedded to massive, polymictic conglomerate and lesser sandstone. Contains abundant clasts of rhyodacite to dacite tuffs and flows, Nikolai Greenstone, argillite, volcanic sandstone, andesite to dacite volcanic rocks of Eagle Creek and Slana Spur Formations, quartz diorite, greenschist, gabbro, and ultramafic rocks. Local thin beds of coal in sandstone layers. Clast composition, south of Chistochina Glacier in Mount Hayes A-2 Quadrangle, in descending order of abundance: Chlorite schist, gabbro, granodiorite, metadiabase, amphibolite, and metagabbro and minor rhyodacite, granite, diabase, metagranodiorite, and quartz. Clast composition south of College Glacier in Mount Hayes A-3 Quadrangle: Argillite, limestone, gabbro, and granitic rocks with minor chert, and metavolcanic rocks. Thickness variable. Maximum exposed stratigraphic thickness of a few hundred meters.

On hill about $6 \mathrm{~km}$ west of Broxson Gulch in Mount Hayes B-5 Quadrangle, conglomerate unit is present and composed predominantly of clasts of ultramafic rocks (Moffit, 1912; Stout, 1976). In Slate Creek area, unit includes "round wash" conglomerate, which contains clasts mainly of metagabbro and diabase, chlorite-epidote schist, amphibolite, granodiorite, and quartz. In area west of Delta River, unit lacks clasts of Maclaren Glacier metamorphic belt that occurs directly north, suggesting that Maclaren Glacier metamorphic belt was faulted into its present position after deposition (Stout, 1976).

Unit occurs in several exposures up to $2 \mathrm{~km}$ across north of McCallum-Slate Creek fault across Mount Hayes A-2 and A-3 quadrangles, and in smaller exposures west of Delta River. Overlies Tertiary volcanic rocks (Tv) and rocks of Slana Spur Formation; locally in fault contact with rocks of Slana Spur Formation.

Unfossiliferous, probably Eocene in age. Relatively younger than underlying, volcanic rocks unit of Eocene age. Relatively older than overlying sandstone and conglomerate unit of Eocene to Miocene age.

\section{TERTIARY VOLCANIC AND INTRUSIVE ROCKS - SOUTH OF DENALI FAULT}

Tv VOLCANIC ROCKS (Eocene) - Chiefly vitric-lithic-crystal ash-flow tuff, breccia, agglomerate, flows, dikes, and sills, and minor volcanic sandstone, conglomerate, and fossiliferous limestone. Igneous rocks mainly volcanic flows and tuffs. Thickness variable. Maximum exposed stratigraphic thickness of a few hundred meters. 
Dacites and andesites generally porphyritic. Composed of phenocrysts and fragments of plagioclase, quartz, and sparse K-feldspar and biotite in relict glassy groundmass, largely replaced by chlorite and lesser sericite and epidote, and local trachytic plagioclase microlites. Locally amygdaloidal. Local veins of quartz and calcite.

Tuffs composed of fragments of sanidine, orthoclase, plagioclase, quartz, and biotite with clear glass shards and lesser lithic fragments from 0.1 to $3.0 \mathrm{~mm}$ across in matrix composed of isotropic, brown glass. Hypautomorphicgranular texture. Plagioclase twinned; locally zoned. Perlitic fractures in larger shards. Lithic fragments mainly siltstone, altered diorite, and andesite or dacite. Slightly welded. Locally weak schistosity. Local intense hydrothermal alteration. Plagioclase partially replaced by sericite, saussurite, and epidote; biotite by chlorite. Abundant hydrothermal alteration near The Hoodoos in northwest Mount Hayes A-3 Quadrangle.

Unit occurs in scattered outcrops up to $3.5 \mathrm{~km}$ across, mainly north of McCallum Creek-Slate Creek fault in southcentral Mount Hayes Quadrangle, and in fault-bounded lenses in splays of Broxson Gulch thrust in southwestern Mount Hayes Quadrangle, and as small dikes in Nikolai Greenstone in southwestern Mount Hayes Quadrangle. Locally overlain by Tertiary sandstone and conglomerate (Tsc) and conglomerate (Tc); locally in fault contact with units Tsc and Tc, and rocks of Slana Spur subterrane. K-Ar isotopic whole-rock analysis of a rhyodacite tuff from about $1.6 \mathrm{~km}$ southeast of The Hoodoos yields an age of $49 \mathrm{Ma}$ (Eocene) (table 2 of Nokleberg and others [1992a], locality 77).

Ta ANDESITE FLOWS (Tertiary[?]) — Consist of fine- to medium-grained hornblende-biotite andesite flows, and contain subhedral to euhedral phenocrysts of hornblende, biotite, plagioclase, and embayed quartz in a groundmass of microcrystalline plagioclase and quartz. Textures are porphyritic, hyalopilitic, and locally glomeroporphyritic. Major primary minerals are quartz, plagioclase, hornblende, and biotite. Replacement minerals are epidote, sericite, and saussurite. Opaques are minor minerals. Plagioclase phenocrysts are normal and oscillatory zoned. Composition varies from $\mathrm{An}_{40}$ to $\mathrm{An}_{35}$. Plagioclase is altered locally to sericite and saussurite. Hornblende is replaced rarely by epidote. Unit occurs in southwestern Gulkana D-3 Quadrangle.

Tl LAMPROPHYRE DIKES (Tertiary)-Intrude Tetelna Volcanics, diorite complex, Ahtell pluton, and Tertiary gabbro and diabase dikes. Occur as narrow dikes a few meters wide and up to $175 \mathrm{~m}$ long. Consist predominantly of dark gray-green porphyritic rocks to less abundant dark brown-gray, fine-grained mafic rocks. The porphyritic rocks contain phyric hornblende and augite with plagioclase in a fine-grained trachytic groundmass. Unit occurs mainly in southeast Mount Hayes and northwest Nabesna quadrangles.

\section{POST-ACCRETIONARY GRANITIC PLUTONIC ROCKS AND DIKES AND SILLS - SOUTH OF DENALI FAULT}

Numerous small to large granitic plutons of Mesozoic and early Cenozoic age occur south of Denali fault in Clearwater, Maclaren, and Wrangellia terranes. Most rocks are unfoliated and igneous textured. These plutons are much younger than the stratified coeval volcanic and plutonic rocks in each terrane, and are interpreted to have formed relatively late in the tectonic history of the region.

grs1 GRANITIC UNIT 1 (Cretaceous and Late Jurassic) — Chiefly granitic and minor monzonite and diorite dikes, stocks, and small plutons. Fine- to medium-grained, hypautomorphic-granular texture. Major minerals are quartz, complexly twinned plagioclase, K-feldspar, local hornblende, biotite, and white mica, and minor sphene, zircon, apatite, and opaque minerals. Local hydrothermal alteration. Weak local deformation resulted in fractured and strained quartz and plagioclase. Locally metamorphosed to lower greenschist facies. Plagioclase partially replaced by sericite, epidote-clinozoisite, and saussurite; hornblende by epidote-clinozoisite, actinolite, and chlorite; biotite by chlorite. Local quartz and calcite veins. Pluton north of McCallum-Slate Creek fault in Mount Hayes A-2 Quadrangle contains gabbro xenoliths.

Unit widely distributed south of Denali fault in Wrangellia and Maclaren terranes in numerous smaller bodies generally less than $1 \mathrm{~km}$ across, and in dikes and sills about $1 \mathrm{~m}$ wide. Locally intruded by small mafic and felsic dikes. Unit occurs mainly in central and southern Mount Hayes Quadrangle.

Unit includes informally named granite of Susitna Glacier (early Tertiary) in north-central Mount Hayes B-6 and southern C-6 quadrangles. Unit consists chiefly of biotite-white mica granite. Fine- to medium-grained, hypautomorphic-granular texture. Major groundmass minerals are quartz, K-feldspar, plagioclase, and biotite. Minor chlorite and opaque minerals. Local hydrothermal alteration, plagioclase partially replaced by white mica. Unit forms large pluton exposed in numerous outcrops up to $7 \mathrm{~km}$ across. Surrounded by glacial deposits, colluvium, and ice. Intrudes schist and amphibolite unit (sa) of East Susitna batholith of Maclaren terrane. Truncated by Denali 
fault along northern margin. K-Ar hornblende and biotite isotopic analyses yield nearly concordant ages of 35.5, 35.6, and 36.1 (table 2 of Nokleberg and others [1992a], localities 48, 54). Early Tertiary ages similar to youngest ages for gneissose granitic rocks in East Susitna batholith of Maclaren terrane; may represent intrusion of part of the batholith in a small area that was tectonically quiet.

Unit also includes informally-named granite porphyry of Caribou Lake (Early Cretaceous and/or Late Jurassic[?]) that crops out in southeastern Mount Hayes A-3 Quadrangle. Consists chiefly of biotite granite porphyry. Fine grained; locally medium grained. Porphyritic with K-feldspar phenocrysts up to $3 \mathrm{~mm}$ diameter. Local hypautomorphicgranular texture. Major groundmass minerals are quartz, plagioclase, and biotite. Minor hornblende, sphene, epidote, and opaque minerals including hematite and white mica. Local extensive hydrothermal alteration. Biotite and hornblende partially replaced by chlorite, feldspar by calcite and white mica. Unit exposed in numerous outcrops up to $5 \mathrm{~km}$ across. Intrudes Nikolai Greenstone of Slana River subterrane of Wrangellia terrane. Locally surrounded by glacial deposits and colluvium. No isotopic age data.

Unit includes several small- to moderate-size plutons that are locally weakly to extensively hydrothermally altered and that intrude Wrangellia terrane. These granitic plutons are interpreted to be at least partly coeval and comagmatic with Upper Jurassic and Lower Cretaceous flysch and volcanic rocks of Gravina-Nutzotin belt, and Lower Cretaceous marine and subaerial andesite volcanic flows and volcaniclastic rocks of Chisana Formation, part of Gravina-Nutzotin belt to the southeast in Nabesna Quadrangle (Richter, 1976). This suite of granitic plutons was also named Gravina arc by Stanley and others (1990). Sparse K-Ar hornblende isotopic analyses yield ages of 129 and $146 \mathrm{Ma}$ (Late Jurassic and Early Cretaceous) (table 2 of Nokleberg and others [1992a], localities 83, 85). However, some Mesozoic(?) granitic plutons in Wrangellia terrane are similar in petrology to Pennsylvanian granitic plutons (PPg) and could be of late Paleozoic age.

grs2 GRANITIC UNIT 2 (Cretaceous and Late Jurassic) — Chiefly hornblende-biotite granodiorite and hornblende granodiorite and minor granodiorite and granite dikes, stocks, and small plutons. Includes sparse syenodiorite and quartz diorite (Richter and others, 1977). Fine- to medium-grained, hypautomorphic-granular texture. Major minerals are plagioclase, quartz, K-feldspar, biotite, and hornblende; minor minerals are white mica, zircon, sphene, and apatite. Locally deformed, exhibiting fractured and strained quartz and feldspar and bent biotite. Locally weakly metamorphosed to greenschist facies. Plagioclase partially replaced by sericite, saussurite, and epidote; biotite and hornblende by chlorite, epidote-clinozoisite, and actinolite. Sparse quartz and calcite veins. Widely distributed south of Denali fault throughout Wrangellia terrane, particularly in Mount Hayes A-1, A-2, and A-3 quadrangles south of Denali fault. Unit occurs in plutons up to $5 \mathrm{~km}$ across, and in numerous dikes and sills up to $500 \mathrm{~m}$ long and $50 \mathrm{~m}$ wide. Dikes usually less than $1 \mathrm{~m}$ wide.

Unit also includes informally-named granodiorite of Rainbow Mountain (Cretaceous and [or] Mississippian) in Mount Hayes B-4 Quadrangle. Northern part of pluton chiefly granite and granodiorite. Fine- to medium-grained, hypautomorphic-granular texture. Major minerals are quartz, K-feldspar, and plagioclase. Minor minerals are epidote, white mica, chlorite, sphene, and opaque minerals. An Early to mid Cretaceous age of intrusion or reheating indicated by a K-Ar hornblende age of about $110 \mathrm{Ma}$ (table 2 of Nokleberg and others [1992a], locality 75). Southern and southeastern part of pluton chiefly biotite-hornblende quartz diorite and granodiorite. Fine- to medium-grained, hypautomorphic-granular texture. Other major minerals are quartz, K-feldspar, and plagioclase. Minor minerals are epidote, white mica, chlorite, sphene, and opaque minerals. Local gneissose texture with moderate schistosity. Plagioclase shows interstitial quartz and K-feldsparLocally, abundant hydrothermal(?) alteration of plagioclase to saussurite, lesser sericite and epidote; biotite and hornblende to chlorite and epidote. Metamorphosed at lower greenschist facies. From 30 to 100 percent of hornblende metamorphosed to chlorite and actinolite; $20-100$ percent of plagioclase metamorphosed to white mica and epidote. A possible Late Mississippian age of intrusion indicated by a K-Ar hornblende age of $326 \mathrm{Ma}$ (table 2 of Nokleberg and others [1992a], locality 76). Both parts of pluton surrounded by glacial deposits, colluvium, and ice in north-central Mount Hayes B-4 Quadrangle and intrude lower volcaniclastic rocks. Member of Slana Spur Formation and shallow-level intrusive stocks, dikes, sills, and small plutons (Early Permian?) of Slana River subterrane of Wrangellia terrane.

grs3 GRANITIC UNIT 3 (Cretaceous and Late Jurassic) - Quartz diorite and diorite dikes, stocks, and small plutons. Fine- to medium-grained, hypautomorphic-granular texture; locally seriate and porphyritic. Composed of plagioclase and hornblende phenocrysts up to $7 \mathrm{~mm}$ long in groundmass of quartz and plagioclase. Local, crude flow-alignment of tabular plagioclase. Local weak deformation resulting in fractured and strained quartz and plagioclase and kink-banded clinopyroxene. Major minerals are plagioclase and quartz and, locally, hornblende and biotite. Minor minerals are K-feldspar, clinopyroxene, sphene, zircon, apatite, and opaque minerals. Normal and oscillatory zoning in plagioclase. Locally granulated phenocrysts. Local greenschist-facies metamorphism; locally 
schistose. Plagioclase partially replaced by sericite, epidote-clinozoisite, and saussurite; hornblende by chlorite, actinolite, and epidote-clinozoisite; biotite by chlorite. Widely distributed south of Denali fault in Clearwater and Wrangellia terranes. Unit occurs in scattered exposures up to about $1 \mathrm{~km}$ across, in numerous smaller bodies, and in dikes and sills about $1 \mathrm{~m}$ wide.

\section{TERRANES - SOUTH OF DENALI FAULT (FROM NORTH TO SOUTH) \\ Terrane of ultramafic and associated rocks - In branches of Denali fault}

A terrane of ultramafic and associated rocks occurs in southeastern Mount Hayes Quadrangle, mainly as a fault-bounded sliver along Denali fault. The terrane is chiefly composed of ultramafic and mafic rocks with lesser metasedimentary rocks and granitic rocks, and represents part of a string of alpine peridotites that occur along or near Denali fault for several hundred kilometers in east-central Alaska (Richter and others, 1977; Nokleberg and others, 1982, 1985). The terrane is found in two settings: (1) A narrow, fault-bounded lens along branches of Denali fault in eastern Mount Hayes Quadrangle in the Gillette Pass area in Mount Hayes A-1, A-2, and A-3 quadrangles (Richter and others, 1977); and (2) as two subhorizontal klippen a few kilometers south of Denali fault in east-central Mount Hayes A-3 Quadrangle between Gakona and Chistochina glaciers (Rose, 1967; Nokleberg and others, 1982). The klippen are floored by subhorizontal thrust faults, and occur structurally on northern margin of Wrangellia terrane. The ultramafic and mafic rocks exhibit a locally well defined, medium- to coarse-grained schistosity that parallels a weak schistosity in the granitic rocks.

The terrane of ultramafic and associated rocks (of probable Mesozoic age) consists chiefly of variably serpentinized pyroxenite, peridotite, dunite, schistose amphibolite, serpentinite, and hornblende-plagioclase gneiss derived from gabbro. Interlayered with gneiss are sparse, thin lenses of light green and gray marble and zones of dark gray graphitic schist. The ultramafic and mafic rocks are intruded by light gray tonalite and granite, and are ductilely deformed and regionally metamorphosed. Estimated structural thickness is a few thousand meters.

The terrane generally strikes west-northwest and dips north or south and its rocks exhibit well-developed schistosity, defined by ductilely deformed, fractured, and granulated mafic minerals. Locally blastomylonitic. The rocks display upper amphibolite-facies metamorphism. Diagnostic minerals are metamorphic clinopyroxene, olivine, hornblende, and calcic plagioclase. Retrogressive lower greenschist-facies metamorphism. Diagnostic minerals are serpentine, chlorite, epidote, talc, and albite.

$\mathrm{K}-\mathrm{Ar}$ isotopic analyses of biotite and hornblende from pyroxenite yield nearly concordant ages of 123 and $126 \mathrm{Ma}$ (table 2 of Nokleberg and others [1992a], localities 80,81). Early Cretaceous ages interpreted as apparent age of regional metamorphism and penetrative deformation of terrane. Age of the protolith of ultramafic and mafic rocks is older, perhaps Paleozoic(?). Relatively younger granitic bodies form elongate plutons and exhibit a weaker fabric than ultramafic and mafic rocks. Relations suggest granitic rocks possibly intruded during regional metamorphism, and penetrative deformation took place in Early Cretaceous. Early Cretaceous ages of metamorphism and deformation for the terrane of ultramafic and associated rocks are similar to interpreted ages of regional metamorphism and penetrative deformation of Yukon-Tanana terrane to the north. Both may have been metamorphosed and deformed during the same event.

The terrane of ultramafic and associated rocks is interpreted as a crustal-suture belt composed of fragments of either oceanic or deep-level continental lithosphere (Richter, 1976; Nokleberg and Richter, 2007). The lithosphere is probably derived from the basement of terranes juxtaposed along Denali fault, such as Yukon-Tanana or Wrangellia terranes (Nokleberg and others, 1989). The two klippen south of Denali fault may represent remnants of amalgamation of Wrangellia terrane along ancestral, continentward-dipping Denali fault.

umg GRANITE AND TONALITE (Cretaceous[?] or older)—Present chiefly in small, elongate plutons intruding amphibole-rich metamorphic rocks. Mottled light gray to light greenish gray. Includes high-soda and high-alumina variants. Fine to medium grained, porphyritic to porphyroblastic. Composed of large phenocrysts or porphyroblasts of sodic plagioclase, generally altered to white mica and clinozoisite, in a groundmass of fine-grained quartz and minor pyroxene and amphibole. Pyroxene and amphibole generally altered to chlorite. Weakly metamorphosed. Unit forms small, elongate plutons intruding amphibole-rich metamorphic rocks of the terrane.

ump PERIDOTITE AND PYROXENITE AND MINOR DUNITE (Cretaceous[?] or older) —Consist of crudely layered elongate bodies associated with amphibolite and hornblende-plagioclase gneiss. Pyroxenite occurs as discrete masses and as thin layers in peridotite. Peridotite, including minor dunite, is largely altered to serpentinite. Fine to medium grained, with relict hypautomorphic-granular texture. Relict igneous minerals are olivine, clinopyroxene, and hornblende and minor biotite and orthopyroxene. Metamorphic minerals mainly serpentine and chlorite. Remnant olivine in the peridotite ranges between $\mathrm{Fo}_{80}$ and $\mathrm{Fo}_{85}$. Olivine partially to completely replaced by serpentine; pyroxene, hornblende, and biotite by chlorite. 
umd DUNITE (Cretaceous[?] or older) - Occurs chiefly in two elongate masses separated from the pyroxenite-peridotite body by amphibole-rich metamorphic rock. Dunite light gray to greenish-gray and massive; average grain size 1-2 mm. Local ductilely deformed fabric containing large olivine grains, smaller than $10 \mathrm{~mm}$, surrounded by finergrained olivine. Local planar shattering of olivine grains. Unevenly distributed grains of chromite locally arranged in short layers. Relict primary minerals mainly olivine and minor plagioclase, clinopyroxene, orthopyroxene, and biotite. Plagioclase saussuritized. Veinlets and cracks throughout the body are generally filled with serpentine, chlorite, talc, and iddingsite. Local gabbro dikes.

uma AMPHIBOLITE AND HORNBLENDE-PLAGIOCLASE GNEISS (Cretaceous[?] or older)—Chiefly consists of massive dark green amphibolite grading into finely banded hornblende-plagioclase gneiss. Fine to medium grained, exhibiting granoblastic textures. Banding thickness and amphibole-feldspar ratio extremely variable. Rare thin lenses of light green and gray, epidote-bearing marble, and zones of dark gray, graphitic schist interlayered with gneiss. Local abundant amphibole-rich pegmatite. Major minerals are green hornblende, calcic plagioclase, quartz, minor clinopyroxene, sulfides, and black oxides. Plagioclase partially replaced by saussurite, sericite, and chlorite; hornblende by chlorite. Carbonate occurs throughout the rock in granular masses and veinlets. Unit forms host to ultramafic rocks. Intruded by tonalite and granite.

\section{Ultramafic and mafic rocks - In branches of Broxson Gulch thrust}

A unit of ultramafic and related rocks occurs in scattered, fault-bounded exposures in branches of Broxson thrust in Mount Hayes B-4, B-5, and B-6 quadrangles. Unit is interpreted either as: (1) Fault-bounded remnants of cumulate mafic and ultramafic rocks in Wrangellia terrane; (2) fault-bounded remnants of other terranes that were tectonically enclosed along Broxson Gulch thrust; (3) a remnant of the terrane of ultramafic and associated rocks that are present along the northern margin of Wrangellia terrane in eastern Mount Hayes Quadrangle; or (4) some combination thereof.

Part of unit may be comagmatic with the unit of cumulate mafic and ultramafic rocks and Nikolai Greenstone, and therefore Late Triassic(?) in age. However, K-Ar isotopic analyses of hornblende in gabbro dikes in picrite sills at two localities in Mount Hayes B-4 Quadrangle yielded ages of ages of 91.9 and $97.7 \mathrm{Ma}$ (table 2 of Nokleberg and others [1992a], localities 73 and 74). Because the cumulate mafic and ultramafic rocks exhibit local, low-grade metamorphism, these Late Cretaceous ages could represent the age of low-grade regional metamorphism of Wrangellia terrane. Alternatively, the ultramafic rocks, which occur in narrow, fault-bounded lenses near or along Denali and Broxson Gulch faults, could represent younger, fault-bounded Late Cretaceous intrusions. In addition to various lithologies of ultramafic rocks, unit includes metagabbro and metadiabase.

um ULTRAMAFIC AND MAFIC IGNEOUS ROCKS (Cretaceous to Triassic[?])—Chiefly dunite, olivine-clinopyroxene cumulates, serpentinite, metagabbro, and metadiabase. Ultramafic rocks possess both cumulate and metamorphic textures; interpreted as probable exposures of dismembered alpine peridotite. The relationship of the mafic rocks to the ultramafic rocks is unclear. Mafic rocks of relatively younger age form dikes in the alpine peridotite; locally may be part of unit of gabbro, diabase, and metagabbro (Trg) that intrudes Late Triassic and older rocks throughout Wrangellia terrane. Estimated structural thickness about 1,500 m.

Dunite medium to coarse grained; exhibits a well-developed crystalloblastic texture. Primary minerals are olivine, commonly kink-banded, and magnetite. Variably altered from nearly fresh to completely serpentinized. Magnetite content varies from about one to ten percent. Weak schistosity and planar fracturing are present locally, as are massive sulfides.

Olivine-clinopyroxene cumulates composed of olivine-clinopyroxene cumulate, clinopyroxene-olivine cumulate, plagioclase-olivine-clinopyroxene cumulate, and plagioclase-orthopyroxene-clinopyroxene-olivine cumulate. Generally medium grained, exhibiting orthocumulate textures. Subhedral to anhedral olivine generally surrounded by anhedral pyroxene. Less abundant euhedral to subhedral pyroxene surrounded by olivine. Plagioclase, comprising up to 20 percent, generally occurs interstitially; however, in one sample it occurs both interstitial to, and poikilitically included in, olivine and clinopyroxene. Olivine varies from about 30 to 90 percent, with an average of 70 percent; clinopyroxene varies from about 5 to 30 percent with an average of 25 percent; orthopyroxene generally present in amounts less than 5 percent. Minor opaque minerals, biotite, and brown hornblende occur locally. Olivine locally replaced by serpentine, and pyroxene and plagioclase by saussurite.

Serpentinite fine to medium grained, locally with mesh texture. Local faint relict cumulate igneous texture. Contains up to 10 percent opaque minerals, some of which occur along vein-like networks. Locally highly sheared.

Metagabbro composed principally of hornblende metagabbro and minor hornblende-clinopyroxene metagabbro and clinopyroxene metagabbro. Mainly relict fine- to medium-grained, hypautomorphic-granular, and lesser subophitic 
texture. Relict minerals are hornblende, plagioclase, and clinopyroxene and local olivine, quartz, biotite, ilmenite, and other opaque minerals. Metamorphic minerals are actinolite, saussurite, sericite, chlorite, clinozoisite-epidote, and serpentine. Clinopyroxene locally replaced by primary hornblende.

Metadiabase composed of hornblende-plagioclase metadiabase and clinopyroxene-plagioclase metadiabase. Fine- to medium-grained, diabasic texture. Relict minerals are plagioclase, clinopyroxene, and hornblende. Metamorphic minerals are actinolite, sericite, chlorite, epidote, and saussurite.

Metagabbro and metadiabase variably metamorphosed at lower greenschist facies. Diagnostic minerals are actinolite, saussurite, sericite, chlorite, and clinozoisite-epidote. Plagioclase partially to completely replaced by saussurite, sericite, chlorite, and epidote; clinopyroxene and hornblende by actinolite, saussurite, epidote, and chlorite; biotite by chlorite; and olivine by serpentine, epidote, and chlorite.

\section{Maclaren terrane - South of Denali fault and north of Broxson Gulch thrust}

Maclaren terrane occurs in southeast corner of map, south of Denali fault. The terrane consists of two major units: (1) Penetratively deformed and regionally metamorphosed granitic plutonic rocks of East Susitna batholith to the north; and (2) schist, amphibolite, phyllite, argillite, and metagraywacke of Maclaren Glacier metamorphic belt to the south (Nokleberg and others, 1981c, 1982, 1985, 1989, 1992b). Contact between East Susitna batholith and Maclaren Glacier metamorphic belt is a faulted intrusive contact termed Meteor Peak fault (Nokleberg and others, 1981c, 1982, 1985, 1992b).

Maclaren terrane is interpreted as a tectonically detached part of a prograde Barrovian-type metamorphic belt and a companion composite continental-margin arc batholith, both intensely metamorphosed and deformed (Smith and Turner, 1973; Turner and Smith, 1974; Nokleberg and others, 1985; Davidson and others, 1992; Nokleberg and Richter, 2007). The increase of metamorphic grade in Maclaren Glacier metamorphic belt toward East Susitna batholith indicates metamorphism occurred in response to syntectonic emplacement and overthrusting of batholith. In addition, similar middle amphibolite facies metamorphism occurs in both schist and amphibolite units of Maclaren Glacier metamorphic belt and East Susitna batholith, and both contain a parallel or subparallel schistosity. This relation indicates that both were regionally deformed and metamorphosed together during the synkinematic intrusion of batholith from Late Cretaceous to middle Tertiary.

East Susitna batholith and Maclaren Glacier metamorphic belt are interpreted as having formed in a continental-margin, Andean-type arc setting (Nokleberg and others, 1985). Locally abundant andesitic and basaltic debris in metagraywacke, abundant quartz detritus in both argillite and metagraywacke, sparse existence of andesite and basalt flows, and sedimentary structures indicating turbidite deposition all suggest that the protolith for the argillite and metagraywacke unit was volcanogenic flysch derived from an Andean-type arc. A continental-margin arc setting is also indicated by common lead compositions for zircon and feldspar (Aleinikoff and others, 1987). Isotopic analysis of lead from samples of East Susitna batholith show moderate radiogenic values, and derivation from a source of about $1.2 \mathrm{Ga}$ age (Aleinikoff and others, 1987).

\section{EAST SUSITNA BATHOLITH, AND SCHIST, QUARTZITE, AND AMPHIBOLITE - SOUTH OF DENALI FAULT AND NORTH OF METEOR PEAK FAULT}

East Susitna batholith consists of five major units: (1) Gneissose granitic rocks (gg); (2) migmatite (mig); (3) migmatitic schist (mgsh); (4) schist and amphibolite (sa); and (5) schist, quartzite, and amphibolite (sq) that occur in roof pendants of metasedimentary rocks. The gneissose granitic plutonic rocks of East Susitna batholith are derived from diorite, granodiorite, and minor granite and locally grade into units of migmatite, migmatitic schist, and schist and amphibolite. The schist and amphibolite unit consists mainly of older, more intensely regionally metamorphosed and penetratively deformed gabbro and diorite and lesser high-grade pelitic sedimentary rocks. East Susitna batholith ductilely deformed and metamorphosed into mylonitic gneiss and schist at upper amphibolite facies, and local retrograde metamorphism at lower greenschist facies (Nokleberg and others, 1985). East Susitna batholith displaced part of Kluane arc of Plafker and others (1989).

Three groups of isotopic ages are determined for East Susitna batholith: (1) A sample of schistose quartz diorite from the batholith yielded a U-Pb zircon age of $70 \mathrm{Ma}$ (Aleinikoff and others, 1981; Davidson and others, 1992); (2) various and abundant K-Ar ages for metamorphic biotite and hornblende range from 87.4 to 29.8 Ma (Nokleberg and others, 1992a); and (3) a sample from the Valdez Creek tonalite in the southern part of batholith in Healy Quadrangle yielded U-Pb zircon ages of 64 to $60 \mathrm{Ma}$ (Davidson and others, 1992; Ridgway and others, 2002). Several observations indicate intrusion of the batholith during regional deformation (syntectonic intrusion) (Nokleberg and others, 1985, 1992b): (1) Occurrence of a parallel regional metamorphic fabric formed at amphibolite facies in both East Susitna batholith and structurally subjacent Maclaren metamorphic belt (described below); and (2) overlapping U-Pb zircon intrusive ages and older ranges of hornblende and biotite metamorphic ages (Late Cretaceous and early Tertiary). 
GNEISSOSE GRANITIC ROCKS (early Tertiary and Late Cretaceous) - Chiefly gneissose granodiorite, quartz diorite, quartz monzonite, and minor granite. Fine to medium grained, with relict hypautomorphic-granular, seriate, and porphyritic textures containing relict phenocrysts of plagioclase and K-feldspar up to $6 \mathrm{~mm}$ across. Relict igneous minerals are plagioclase, quartz, K-feldspar (locally perthitic), biotite, hornblende rimmed by biotite, and clinopyroxene rimmed by biotite and hornblende. Minor zircon and apatite. Relict igneous hornblende rimmed by igneous biotite; clinopyroxene by biotite and minor hornblende. Clinopyroxene and hornblende commonly poikiloblastic, containing abundant inclusions of feldspar and quartz. Strong undulose extinction in feldspar and quartz augen. Relict igneous plagioclase with complex twinning, normal zoning, and oscillatory zoning. Sparse crosscutting dikes of nonfoliated gabbro, diabase, rhyodacite, and rhyolite. Locally grades to migmatite.

Unit exhibits single pervasive schistosity that generally strikes northwest to southwest, dips moderately to steeply west, and parallels younger structures in part (msh) of Maclaren Glacier metamorphic belt to south in Mount Hayes B-6 Quadrangle. Penetratively deformed. Locally grades to blastomylonite. Schistosity defined by parallel-aligned biotite, white mica, and elongate grains and augen of quartz and feldspar.

Unit metamorphosed at middle to upper amphibolite facies. Diagnostic amphibolite-facies minerals are recrystallized clinopyroxene, hornblende, calcic plagioclase, and garnet. Locally retrogressively metamorphosed to greenschist facies. Diagnostic lower greenschist-facies minerals are white mica, epidote-clinozoisite, and chlorite. Biotite, hornblende, and clinopyroxene partially replaced by chlorite; plagioclase by epidote and white mica; K-feldspar by white mica. Local intense granulation along margins of feldspar and quartz augen.

Unit well exposed between Denali fault to the north and Meteor Peak fault to the south in Mount Hayes B-4, B-5, and B-6 quadrangles. Unit also occurs in branches of Meteor Peak fault in Mount Hayes B-6 Quadrangle. Intrudes, and locally faulted against, schist and amphibolite (sa) of Maclaren Glacier metamorphic belt.

$\mathrm{U}-\mathrm{Pb}$ zircon, $\mathrm{U}-\mathrm{Pb}$ sphene, and $\mathrm{K}-\mathrm{Ar}$ mica and hornblende isotopic analyses yield a wide range of ages between 70.0 and 29.2 Ma (table 2 of Nokleberg and others [1992a], localities 42, 44, 45, 49, 53, 56-69). Oldest isotopic age of $70 \mathrm{Ma}$ from a U-Pb zircon analysis of a gneissose granodiorite (table 2 of Nokleberg and others [1992a], locality 45). Oldest, nearly concordant $\mathrm{K}$-Ar hornblende and biotite isotopic ages from a single sample of 65.9 and 56.9 Ma (table 2 of Nokleberg and others [1992a], locality 50). To the west in Healy Quadrangle, oldest K-Ar hornblende isotopic age 87.4 Ma (Turner and Smith, 1974; Csejtey and others, 1992). Ages interpreted as Late Cretaceous intrusion of this part of East Susitna batholith, and continued syntectonic intrusion, regional metamorphism, and penetrative deformation in early Tertiary (Nokleberg and others, 1985, 1989).

Other, younger isotopic ages range from about $56 \mathrm{Ma}$ to $30 \mathrm{Ma}$. A U-Pb isotopic analysis of deformed and metamorphosed sphene yields an age of metamorphism of $56 \mathrm{Ma}$ from sample of gneissose granodiorite that exhibits a U-Pb zircon igneous age of $70 \mathrm{Ma}$ (table 2 of Nokleberg and others [1992a], locality 45). Metamorphic biotite from this sample yields a K-Ar age of 56.9 Ma. These and similar ages interpreted as regional metamorphism and penetrative deformation of this granodiorite that occurred after intrusion (Nokleberg and others, 1985).

The youngest K-Ar isotopic ages of 29.2 and $36.6 \mathrm{Ma}$ for muscovite, biotite, and hornblende (table 2 of Nokleberg and others [1992a], localities 56-65, 67-69) tend to occur close to Denali fault; interpreted as either continued, syntectonic intrusion of parts of East Susitna batholith, or unroofing and cooling of East Susitna batholith during lateral migration along Cenozoic Denali fault. General parallelism of schistosity in the batholith with Denali fault suggests that some metamorphism and deformation of the batholith occurred during faulting (Nokleberg and others, 1985).

SCHIST AND AMPHIBOLITE (Late Cretaceous or older) - Chiefly garnet-biotite-plagioclase schist and hornblende amphibolite. Relatively older, more mafic, and more highly metamorphosed variation of gneissose granitic rocks (gg), which locally intrude this unit. Intensely regionally metamorphosed and penetratively deformed gabbro, quartz gabbro, diorite, and quartz diorite recrystallized to garnet-biotite-plagioclase schist and amphibolite. Includes local pelitic schist and pelitic gneiss. Fine to medium grained. Mainly schistose aggregates of clinopyroxene, hornblende, biotite, plagioclase, and quartz, and lesser calcite, garnet, chlorite, epidote, white mica, and calcite. Very sparse relict hypautomorphic-granular texture. Relict igneous plagioclase, biotite, hornblende, quartz, and clinopyroxene.

Unit intensely regionally metamorphosed and penetratively deformed. Schistosity generally strikes north or northwest and dips moderately north. Locally migmatitic. Local intense granulation and strong undulose extinction in quartz and feldspar augen. Metamorphosed to amphibolite facies. Diagnostic amphibolite facies minerals are hornblende, biotite, and garnet. Local retrogressive metamorphic overprint at lower greenschist facies with partial 
replacement of clinopyroxene by biotite and hornblende; garnet by chlorite and white mica; plagioclase by white mica and calcite. Well exposed north of Meteor Peak fault in central and northern Mount Hayes B-6 and eastern B-5 quadrangles.

mig MIGMATITE (Cretaceous[?])—Transitional rock unit between migmatitic schist (mgsh) and gneissose granitic rocks (gg). Grades from gneissose granitic rocks (gg), containing fragments of nearly completely assimilated schist and amphibolite, to highly contorted schist and amphibolite with diffuse veins of granodiorite to diorite. Contains abundant small to large diffuse dikes of granitic rock. Granitic rock dikes grade laterally into gneissose granitic rocks (gg) of East Susitna batholith. Locally contains pods and veins of rose quartz. Swirly schistosity. Fine to medium grained. Major minerals are plagioclase, quartz, and biotite. Lesser hornblende, K-feldspar, white mica, garnet, and minor chlorite also present. Plagioclase partially replaced by white mica.

Unit occurs in outcrops up to $1 \mathrm{~km}$ across in northwestern Mount Hayes B-6 Quadrangle. Interpreted as a possible partial melting product that formed during the Late Cretaceous and early Tertiary intrusion of East Susitna batholith.

mgsh MIGMATITIC SCHIST (Cretaceous[?])—Grades from schist and amphibolite (sa), containing diffuse granitic dikes concordant with schistosity, to contorted and partly assimilated schist and amphibolite. Grades laterally into migmatite (mig). Contains fewer granitic dikes than migmatite (mig). Attitude of schistosity consistent in large outcrops. Diffuse granitic dikes composed of fine- to medium-grained hypautomorphic-granular to schistose aggregates of biotite, plagioclase, quartz, and K-feldspar. Major minerals are hornblende, biotite, plagioclase, quartz, clinozoisite, white mica, and lesser garnet, K-feldspar, and chlorite. Transitional rock type between migmatite (mig) and schist and amphibolite (sa).

Unit occurs in a cluster of exposures, individually up to $3 \mathrm{~km}$ across, and jointly comprising two large bodies up to $10 \mathrm{~km}$ across in gneissose granitic rocks ( $\mathrm{gg}$ ) and schist and amphibolite (sa) in northwestern Mount Hayes B-6 Quadrangle. Unit interpreted as possible partial melting products formed during Late Cretaceous and early Tertiary intrusion of East Susitna batholith.

Ages similar to those in unit of gneissose granitic rocks (gg). The oldest nearly concordant K-Ar hornblende and biotite isotopic ages are from a single sample of 65.9 and $56.9 \mathrm{Ma}$ (table 2 of Nokleberg and others [1992a], locality 50). Other K-Ar hornblende ages range from 61.7 to $58.5 \mathrm{Ma}$ (table 2 of Nokleberg and others [1992a], localities $43,47,51,52$ ), and K-Ar biotite ages of 31.9, 33.7, and 55.9 Ma (table 2 of Nokleberg and others [1992a], localities 53,56). Younger isotopic ages interpreted as either continued syntectonic intrusion, or unroofing and cooling.

SCHIST, QUARTZITE, AND AMPHIBOLITE (Triassic[?])—Unit of relatively older calc-silicate schist, quartzite, and amphibolite. Moderately to intensely deformed with moderate schistosity. Fine to medium grained. Intruded by various metamorphosed granitic rocks of East Susitna batholith. Estimated structural thickness of a few hundred meters.

Calc-silicate schist and amphibolite mainly fine to medium grained and strongly schistose. Major minerals in calc-silicate schist are plagioclase, hornblende, clinopyroxene, quartz, and calcite. Minor minerals are garnet and clinozoisite. Garnet partially replaced by clinozoisite. Derived mainly from marl.

Quartzite varies from fine to medium grained. Schistose texture. Contains both fractured and undulatory quartz; minor K-feldspar, biotite, hornblende, and epidote.

Amphibolite consists of schistose plagioclase, hornblende, and biotite. Minor minerals are clinopyroxene and opaque minerals. Clinopyroxene mostly replaced by hornblende and plagioclase. Derived mainly from marl.

Unit occurs in west-central part of Mount Hayes Quadrangle, south of Denali fault in small roof pendants in East Susitna batholith. Lithologically similar rocks on strike in Healy Quadrangle to west contain Pennsylvanian to Triassic conodonts (Sherwood and Craddock, 1979; Csejtey and others, 1992) and fragments of bivalves of Late Triassic age (Jones and others, 1987). Correlated with Nenana terrane of Jones and others (1987). Intruded by gneissose granitic rocks (gg) of East Susitna batholith.

\section{Maclaren Glacier metamorphic belt - SOUth of Meteor Peak fault and north of BROXSON GULCH THRUST}

Maclaren Glacier metamorphic belt occurs to the south of the East Susitna batholith and is a prograde Barrovian-type metamorphic belt. From south to north, major units are: (1) Upper Jurassic or older argillite and metagraywacke; (2) phyllite; 
and (3) quartz-mica schist, calc-schist, and amphibolite (Nokleberg and others, 1985, 1992b). Contacts between the three major units are faults exhibiting abundant brittle shears (microfaults) and abrupt changes of metamorphic facies at each surface. Late Jurassic or older age is based on correlation with a similar Upper Jurassic unit about $400 \mathrm{~km}$ to the southeast on opposite side of Denali fault (Nokleberg and others, 1985, 1989; Nokleberg and Richter, 2007).

Maclaren Glacier metamorphic belt occurs to the south of the East Susitna batholith and is a prograde Barrovian-type metamorphic belt. From south to north, principal units of Late Jurassic or older argillite and metagraywacke (ma), phyllite (mph), and quartz-mica schist, calc-schist, and amphibolite (msh) (Nokleberg and others, 1982, 1985). Contacts between the three map units are generally faults exhibiting intense shearing and abrupt changes of metamorphic facies at each contact.

The protolith for sedimentary and volcanic rocks of the metamorphic belt is in part Late Jurassic or older in age. To the west in southeastern Healy Quadrangle, an alkali gabbro pluton that intrudes southern part of metamorphic belt yielded discordant K-Ar isotopic ages of 146 Ma for hornblende and 133 Ma for biotite (Turner and Smith, 1974; Smith, 1981; Csejtey and others, 1992). These relations suggest that at least part of the protolith is Late Jurassic and possibly older. A minimum age for the protolith is indicated by intrusion of dikes of Late Cretaceous and early Tertiary East Susitna batholith into quartz-mica schist, calc-schist, and amphibolite unit of metamorphic belt.

Maclaren Glacier metamorphic belt is ductilely deformed into protomylonite and phyllonite in argillite and metagraywacke unit, phyllonite in phyllite unit, and mylonitic schist in quartz-mica schist, calc-schist, and amphibolite unit. Metamorphic grade generally increases from argillite and metagraywacke unit in the south to quartz-mica schist, calc-schist, and amphibolite unit in the north, grading from lower greenschist facies in argillite and metagraywacke unit to lower or middle amphibolite facies metamorphism in quartz-mica schist, calc-schist, and amphibolite unit (Nokleberg and others, 1985, 1989).

msh QUARTZ-MICA SCHIST, CALC-SCHIST, AND AMPHIBOLITE (Late Jurassic or older) — Chiefly quartz-mica schist, amphibolite, and calc-schist. Protoliths chiefly pelite, sandstone, and graywacke with minor marl, andesite, and gabbro. Grain size of 0.1 to $0.3 \mathrm{~mm}$. Estimated structural thickness about $6,700 \mathrm{~m}$.

Quartz-mica schists consist of white mica-quartz schist, biotite-white mica-quartz schist, garnet-white mica-quartz schist, biotite-quartz schist, plagioclase-white mica-quartz schist, and plagioclase-chlorite-quartz-white mica schist. Generally fine grained. Major minerals are plagioclase and garnet porphyroblasts and quartz augen up to $4 \mathrm{~mm}$ across. Minor minerals are calcite, epidote-clinozoisite, apatite, graphite, opaque minerals, hornblende, staurolite, and tourmaline. Sparse relict clastic quartz and plagioclase grains. Complicated twinning and zoning in relict plagioclase. Local helicitic and rolled garnet. Locally abundant poikiloblastic plagioclase whose cores contain relict phyllite defined by schistose aggregates of graphite, white mica, and clinozoisite. Sparse sillimanite and kyanite observed in rocks of appropriate bulk composition by Stout (1976), but not observed in this study.

Amphibolite, derived from marl, composed of schistose hornblende, garnet, biotite, quartz, plagioclase, and calcite. Rolled hornblende and garnet porphyroblasts exhibit relict schistosity. Amphibolite derived from gabbro. Exhibits relict hypautomorphic-granular texture. Major minerals are plagioclase, hornblende, white mica, and minor chlorite. Calc-schist composed of hornblende-clinozoisite schist and calcite schist. Minor minerals are white mica, quartz, chlorite, and plagioclase.

Unit intensely deformed with a strong schistosity. Two generations of isoclinal folds occur with opposite vergences, with axial planes parallel to schistosity. Older generation folds generally show north vergence whereas youngergeneration folds generally show south vergence. Near Broxson Gulch thrust to the south, axial planes of folds, schistosity, and subparallel compositional layering in the metamorphic belt generally dip moderately to steeply north, whereas to the north, these structures dip steeply south, parallel to Meteor Peak fault. This change in dip of schistosity and other structures defines a large overturned antiform that extends from just west of Delta River to near the western edge of Mount Hayes Quadrangle.

Unit metamorphosed to amphibolite facies. Diagnostic minerals are hornblende, staurolite, calcic plagioclase, biotite, and garnet. Local retrogressive metamorphism to greenschist facies. Diagnostic greenschist-facies minerals are chlorite, epidote-clinozoisite, and white mica. Hornblende partially replaced by biotite and chlorite; garnet by biotite; biotite by white mica; plagioclase by sericite and epidote.

Unit well exposed between Meteor Peak fault and Broxson Gulch thrust in southwestern Mount Hayes Quadrangle. Intruded by small dikes and sills of East Susitna batholith and by locally pegmatitic granodiorite. Faulted against gneissose granitic rocks ( $\mathrm{gg}$ ) and phyllite ( $\mathrm{mph}$ ) to the north and rocks of Wrangellia terrane to the south.

$\mathrm{K}-\mathrm{Ar}$ isotopic analyses of biotite and muscovite from schist and amphibolite unit range from 48.0 to $30.6 \mathrm{Ma}$ (table 2 of Nokleberg and others [1992a], localities 70-72). One K-Ar hornblende isotopic analysis yields an age of 69.6 
Ma (table 2 of Nokleberg and others [1992a], locality 70). Oldest isotopic age of 69.6 Ma may represent prograde regional metamorphism and penetrative deformation during syntectonic intrusion of parts of East Susitna batholith, described above. Younger K-Ar mica ages may represent either retrograde metamorphism and/or unroofing and cooling of Maclaren terrane during lateral migration along Cenozoic Denali fault. Late Jurassic or older age for protolith.

mph PHYLLITE (Late Jurassic or older) - Chiefly fine-grained white mica-quartz phyllite, and minor quartz-plagioclase-white mica phyllite, clinozoisite-chlorite-quartz phyllite, calcite-chlorite phyllite, and quartz-rich marble and meta-andesite. Protoliths mainly siltstone, metavolcanic siltstone, marl, limestone, and andesite. Estimated structural thickness about $2,400 \mathrm{~m}$.

Fine grained, grain size approximately 0.05 to $0.1 \mathrm{~mm}$. Minor metamorphic minerals are garnet, graphite, and sphene. Porphyroblasts of quartz, plagioclase, and garnet up to $1.5 \mathrm{~mm}$ across. Relict clastic quartz grains up to 2 $\mathrm{mm}$ across. Complexly twinned and zoned plagioclase porphyroclasts. Local grain-size variation parallels schistosity. Local carbonate-rich layers. Local relict patches or areas of argillite and metagraywacke (ma). Meta-andesite composed of plagioclase microlites with mafic minerals replaced by chlorite and opaque minerals. Local extensive sericite alteration. Metavolcanic graywacke contains clasts of relict igneous plagioclase exhibiting complicated twinning, normal, and oscillatory zoning.

Unit intensely deformed; exhibits strong schistosity. Numerous isoclinal folds and axial plane faults parallel to schistosity. Variably fractured and granulated quartz and plagioclase. Schistosity generally parallels Broxson Gulch thrust and dips moderately to steeply north. Locally intensely sheared. Local relict bedding. Metamorphosed to upper greenschist facies. Diagnostic minerals are biotite and garnet. Local retrogressive lower greenschist facies indicated by partial replacement of garnet by clinozoisite, and plagioclase by white mica.

Unit well exposed in Mount Hayes B-5 and B-6 quadrangles between Broxson Gulch thrust and Meteor Peak fault. Generally faulted against quartz-mica schist, calc-schist, and amphibolite (msh) to the north, and argillite and metagraywacke (ma) to the south. Interpreted as an intermediate, metamorphic-grade part of metamorphic belt, between units ma and msh.

ma ARGILLITE AND METAGRAYWACKE (Late Jurassic or older) — Chiefly argillite, metagraywacke, and metaandesite locally. Protoliths of siltstone, calcareous mudstone, and volcanic graywacke. Average grain size $0.01-0.05$ $\mathrm{mm}$. Estimated structural thickness about 2,000 m.

Argillite composed principally of graphite-quartz argillite and lesser calcite-biotite-white mica argillite. Major minerals are graphite, quartz, epidote, chlorite, plagioclase, white mica, calcite, and biotite. Locally graded beds display quartz-rich bases and graphite-rich tops. Sparse relict clastic grains.

Metagraywacke composed of white mica, clinozoisite, quartz, graphite, plagioclase, chlorite, and lesser calcite and opaque minerals. Abundant relict resorbed quartz phenocrysts, and lesser relict igneous plagioclase exhibiting normal and oscillatory zonation, and complicated twinning. Locally abundant graded bedding, load casts, bimodal grain distribution, and wavy cross lamination (Nokleberg and others, 1982; Smith, 1981).

Unit strongly schistose. Schistosity generally strikes northeast and dips moderately to steeply north or south. Locally refolded into isoclinal folds. Intensely faulted and sheared. Variably fractured and granulated quartz and plagioclase. Metamorphosed to lower greenschist facies. Diagnostic minerals are graphite, chlorite, clinozoisite, and white mica. Plagioclase partially replaced by white mica.

Unit occurs in southwestern Mount Hayes B-6 and northwestern A-6 quadrangles between Broxson Gulch thrust and Meteor Peak fault to the north. Generally faulted against phyllite (mph) to the north and against rocks of Clearwater and Wrangellia terranes to the south along Broxson Gulch thrust. Intruded by local, small rhyodacite and granite dikes of Late Cretaceous or early Tertiary age.

\section{Clearwater terrane - In branches of Broxson Gulch thrust}

Clearwater terrane (Jones and others, 1987; Nokleberg and others, 1982, 1985) occurs in western Mount Hayes A-6 Quadrangle as a narrow, fault-bounded lens along Broxson Gulch thrust between Maclaren terrane to the north and Wrangellia terrane to the south. Clearwater terrane consists of highly deformed chlorite-calcite-quartz schist, quartz-muscovite schist, Upper Triassic marble, greenstone derived from pillow basalt, and sparse metadacite. Metamorphosed at lower greenschist facies. Diagnostic minerals are sericite, epidote, chlorite, and actinolite. Clearwater terrane interpreted as a small fragment of a Late Triassic island arc. 
$\mathrm{cm}$ SCHISTOSE MARBLE (Triassic) - Chiefly consists of calcite grains up to $7 \mathrm{~mm}$ across in very-fine-grained schistose matrix of calcite and sparse grains and augen of quartz. Very fine to fine grained, average grain size varies from 0.02 to $2 \mathrm{~mm}$. To the west in southeastern Healy Quadrangle, marble layers in sedimentary rocks correlative with Clearwater terrane contain Heterastridium sp. of Late Triassic age (Jones and others, 1987; Csejtey and others, 1992).

csm SCHISTOSE METASEDIMENTARY AND METAVOLCANIC ROCKS (Late Triassic)—Chiefly fine-grained quartz-white mica-schist, chlorite-calcite-quartz schist, marble, greenstone, and sparse metadacite. Protoliths of quartz siltstone, calcareous sandy siltstone, limestone, fine-grained basalt, and fine-grained dacite. Strongly faulted and fault bounded. Estimated structural thickness of a few thousand meters.

Quartz-white mica-schist composed of relict clastic grains of quartz, plagioclase, and K-feldspar in a matrix of very-fine-grained quartz and abundant schistose sericite. Feldspars form granular streaks and augen, largely replaced by sericite, and accompanied by concentrations of brown iron oxide. Sparse patches of calcite. Abundant fracturing and granulation. Average grain size $0.02-0.5 \mathrm{~mm}$. Chlorite-calcite-quartz schist composed of relict grains of calcareous sand up to $5 \mathrm{~mm}$ across in a schistose matrix of very-fine-grained chlorite, calcite, and quartz. Major minerals in schist include quartz, white mica, calcite, and chlorite.

Greenstone composed of plagioclase phenocrysts and sparse glomerocrysts, up to $1.5 \mathrm{~mm}$ and averaging 0.5 $\mathrm{mm}$ long, in groundmass of clinopyroxene largely replaced by chlorite, actinolite, epidote, and locally by turbid, brown, cryptocrystalline material. Relict ophitic texture. Local pillow structure. Sparse calcite and chlorite veins. Clinopyroxene partially replaced by chlorite, actinolite, epidote, and plagioclase.

Metadacite composed of relict quartz and plagioclase microphenocrysts, averaging 1.0-1.5 mm across, in a matrix of very-fine-grained granular quartz and varying proportions of schistose white mica, chlorite, and calcite. Major relict minerals are quartz and plagioclase; secondary minerals are calcite, quartz, white mica, chlorite, apatite, and opaque minerals. Relict plagioclase phenocrysts euhedral to anhedral; usually exhibits albite twinning. Local extensive calcite replacement of relict plagioclase phenocrysts and matrix.

Unit exhibits weak schistosity that strikes northeast to east and dips moderately to steeply north. Local phyllonite occurs parallel to schistosity. Clasts in metamorphosed fine-grained detrital rocks flattened parallel to schistosity. Metasedimentary rocks locally display relict bedding.

Unit occurs in fault-bounded block in branches of Broxson Gulch thrust in northwestern Mount Hayes A-6 Quadrangle. Faulted against Maclaren terrane to the northwest and Wrangellia terrane to the southeast. Unit includes a small exposure of fault-bounded diorite and quartz diorite (grs3).

\section{Wrangellia terrane - South of Broxson Gulch thrust and Denali fault}

Wrangellia terrane (Jones and others, 1987; Nokleberg and others, 1982, 1985, 1989) is subdivided into Slana River subterrane to the north, and Tangle subterrane to the south (Nokleberg and others, 1981a, b, 1982, 1985), and occurs across southern Mount Hayes Quadrangle. Slana River subterrane is bounded to the north by Broxson Gulch thrust and to the south by Eureka Creek fault. Tangle subterrane occurs south of Eureka Creek fault. Wrangellia terrane is weakly regionally metamorphosed at lower greenschist facies (Nokleberg and others, 1985). Metamorphic minerals generally fine grained and disseminated; abundant relict minerals present in most rocks.

Slana River and Tangle subterranes exhibit significantly different stratigraphies, as described below, which indicate important differences in origin (Nokleberg and others, 1981a, b; 1985): (1) In Tangle subterrane, upper Paleozoic rocks formed in deep water at some distance from a site of submarine island-arc volcanism, whereas in Slana River subterrane the upper Paleozoic rocks formed along an axis of submarine volcanism; (2) in Tangle subterrane, Triassic rifting and basaltic volcanism were initially submarine and closer to the axis of rifting, whereas in Slana River subterrane, Triassic rifting and basaltic volcanism were initially subaerial and probably commenced later and farther from the axis of rifting; (3) during later stages of rifting, basaltic volcanism was much more voluminous in Tangle subterrane than in Slana River subterrane; and (4) in Slana River subterrane, oceanic and continental-margin sedimentation continued through Jurassic and Cretaceous, whereas no similar event is preserved in Tangle subterrane.

These differences in geologic history suggest that Tangle and Slana River subterranes (1) Represent distal and proximal parts, respectively, of same late Paleozoic island-arc; (2) represent proximal and distal parts, respectively, of same Triassic rift system; and (3) have been considerably shortened tectonically, and juxtaposed during terrane migration and accretion. 
Three major geologic events occurred in origin and evolution of Wrangellia terrane. These events were first summarized by Richter and Jones (1973), and later amplified by Nokleberg and others (1985), and Nokleberg and Richter (2007). Each event contributed to formation of one of the three major stratigraphic units in Wrangellia.

The first event was formation of late Paleozoic submarine volcanic and associated sedimentary rocks and plutonic rocks of Skolai arc (Bond, 1973, 1976; Richter and Jones, 1973; Nokleberg and others, 1985; Barker and Stern, 1986). The main evidence for an island-arc origin of late Paleozoic volcanic and associated rocks is: (1) Submarine deposition of volcanic flows, tuff, and breccia, and associated volcanic graywacke and argillite of Slana Spur Formation and Tetelna Volcanics (Bond, 1973, 1976); (2) little or no quartz in volcanic rocks and associated shallow-intrusive bodies; (3) locally abundant features that indicate turbiditic deposition of sedimentary and volcanic debris to form volcanic graywacke; and (4) absence of abundant continental crustal detritus in upper Paleozoic stratified rocks (Richter, 1976; Nokleberg and others, 1982). In addition, common lead isotopic compositions for late Paleozoic granitic rocks intruding Wrangellia terrane are low in radiogenic lead, and are derived from a mixture of oceanic mantle and pelagic sediment leads, without an older continental component (Aleinikoff and others, 1987).

The second event was rifting that formed the Upper Triassic Nikolai Greenstone and associated gabbro dikes and cumulate mafic and ultramafic sills (Richter and Jones, 1973; Jones and others, 1977; Nokleberg and others, 1985). The main evidence for a rift origin of Nikolai Greenstone and associated intrusive rocks is: (1) The vast extent and great thickness throughout Wrangellia terrane (Jones and others, 1977); (2) the relatively constant originally igneous composition and texture (Jones and others, 1977; MacKevett, 1978; Winkler and others, 1981; Nokleberg and others, 1982); (3) an average chemical composition approximating a typical tholeiite (MacKevett and Richter, 1974; Silberling and others, 1981); (4) REE analyses compatible with [back-arc] spreading (Barker and others, 1989); and (5) the narrow age range for extrusion of the basalt (Jones and others, 1977). However, studies by Richards and others (1991) suggest formation in a mantle plume setting. The main evidence cited for a plume origin is: (1) Lack of sheeted dikes and rift structures; (2) no indication of crustal extension; and (3) a relatively short-lived period of mainly mafic volcanism that commenced with submarine and ended with subaerial eruption.

The third event was formation of a marginal flysch basin into which was deposited Upper Jurassic and Lower Cretaceous argillite, graywacke, conglomerate, and andesite of Gravina-Nutzotin belt onto the northern edge of Wrangellia terrane (Berg and others, 1972; Richter and Jones, 1973; Nokleberg and others, 1985). Abundant volcanic-derived detritus in the flysch, associated andesite volcanic and volcaniclastic rocks of Lower Cretaceous Chisana Formation, and sparse coeval granitic plutonic rocks are interpreted as portions of Gravina or Chisana arc, which formed along the margin of Wrangellia terrane (Plafker and others, 1989; Stanley and others, 1990). The main evidence for deposition of Gravina-Nutzotin belt in a flysch basin on the accreting margin of Wrangellia terrane is the derivation of clasts in conglomerate, some from Wrangellia terrane, and some from a continental source (Berg and others, 1972; Richter, 1976). Local andesitic and volcanic detritus in graywacke, and abundant andesite flows and breccia in upper part of belt (Berg and others, 1972; Richter, 1976) suggest a short-lived island arc built on the leading edge of Wrangellia terrane as it neared North America.

\section{FAULT-BOUNDED WEDGE OF MCCARTHY FORMATION}

Jkm McCARTHY FORMATION (Early Jurassic and Late Triassic) - Chiefly rhythmically, thin- to medium-bedded, calcareous argillite and impure limestone, mainly spiculitic, skeletal, or intraclastic lime packstone (Silberling and others, 1981). Estimated maximum stratigraphic thickness of a few hundred meters.

Limestone contains abundant, poorly preserved and recrystallized fossils up to $0.5 \mathrm{~mm}$ across, each composed of one to several calcite crystals. Fossils occur in fine-grained, turbid, green-brown calcareous matrix containing sparse veins of coarser calcite. Fossil material tentatively identified as radiolarians, sparse sponge spicules, and rare benthic foraminifers. Calcareous shales contain distinctive occurrence of Monotis M. subcircularia(?), and indicate a Late Triassic age for part of this unit in Mount Hayes Quadrangle (table 1 of Nokleberg and others [1992a], localities 121, 122).

Unit occurs in a narrow, fault-bounded lens along branches of Broxson Gulch thrust in western Mount Hayes A-6 Quadrangle between Clearwater terrane to the north and Wrangellia terrane to the south. The nearest other occurrence of McCarthy Formation is about $220 \mathrm{~km}$ to the southeast in the type area in McCarthy Quadrangle, where age ranges from Late Triassic to Early Jurassic (MacKevett, 1978).

\section{GABBRO, DIABASE, AND METAGABBRO, AND CUMULATE MAFIC AND ULTRAMAFIC ROCKS}

Locally extensive gabbro dikes, small sills, large, cumulate mafic and ultramafic sills, and small plutons intrude Nikolai Greenstone and older rocks throughout Slana River subterrane. Interpreted as comagmatic with basalts that formed Nikolai 
Greenstone (Nokleberg and others, 1982, 1985). Cumulate ultramafic rocks include Fish Lake Complex of Stout (1976). Estimated thickness of a few thousand meters.

kg GABBRO, METAGABBRO, AND DIABASE (Late Triassic[?])—Chiefly hornblende gabbro, clinopyroxene gabbro, and hornblende-clinopyroxene gabbro, and sparse quartz gabbro and hornblende quartz diorite. Dark gray, fine- to medium-grained, and mainly relict hypautomorphic-granular texture, but locally porphyritic, ophitic to subophitic, and diabasic. Porphyritic variants contain relict phenocrysts of plagioclase up to $3 \mathrm{~mm}$ long. Relict primary minerals are clinopyroxene and plagioclase; local hornblende, biotite, quartz, magnetite, and sparse olivine. Metamorphic minerals are chlorite, white mica, actinolite, quartz, calcite, epidote, and zeolites. Clinopyroxene commonly twinned and zoned and locally rimmed by igneous hornblende. Hornblende locally replaced by igneous biotite. Locally intensely metamorphosed and weakly schistose. Variably fractured and granulated. Metamorphosed to lower greenschist facies. Diagnostic minerals are chlorite, epidote, actinolite, white mica, and calcite. Clinopyroxene partially replaced by actinolite, chlorite, and epidote; hornblende by chlorite, epidote, and actinolite; plagioclase by white mica, epidote, and saussurite.

Numerous sills, too small to be depicted on map, occur in lower limestone member of Eagle Creek Formation in southeastern Mount Hayes Quadrangle. Intrude Nikolai Greenstone and older rocks in both Slana River and Tangle subterranes. Interpreted as forming in late-magmatic stage of eruption of mafic lavas that formed Nikolai Greenstone (Nokleberg and others, 1985). Only larger bodies shown on geologic map. In some areas, may be late Paleozoic in age and part of igneous suite in Slana Spur Formation and Tetelna Volcanics.

kcg CLINOPYROXENE-HORNBLENDE STOCKS AND PLUGS (Late Triassic[?])—Occurs in northern Gulkana D-2 and D-3 quadrangles; less than $2 \mathrm{~km}$ in diameter. Consists of medium-grained, dark gray-green clinopyroxene-hornblende gabbro. Metamorphosed at lower greenschist facies. Textures are subhedral granular and locally subophitic. Major primary minerals are clinopyroxene, hornblende, and plagioclase. Sphene, opaques, and rarely olivine are minor minerals. Chlorite, muscovite, saussurite, serpentine, epidote, and actinolite occur as replacement minerals. Composition ranges from $\mathrm{An}_{42}$ to $\mathrm{An}_{55}$. Hornblende is extensively replaced by chlorite and actinolite. Clinopyroxene is altered to chlorite. Plagioclase is highly altered to sericite and saussurite. Olivine is almost completely (90 percent) altered to serpentine.

koc OLIVINE CUMULATE (Late Triassic[?])—Chiefly composed of fine- to medium-grained aggregates of euhedral to subhedral olivine and sparse chromite in a matrix of overgrown olivine, clinopyroxene, or plagioclase. Locally aligned tabular olivine. Local layering defined by variation in grain size and serpentinization. Generally intensely serpentinized with olivine replaced by serpentine, magnetite, and talc, and matrix replaced by chlorite and/or sericite. Common undulose extinction and kink banding in olivine. Relict cumulate texture in intensely serpentinized samples. Variably fractured, granulated, and deformed.

kopc OLIVINE-PYROXENE CUMULATE (Late Triassic[?]) - Chiefly composed of fine- to medium-grained aggregates of euhedral to subhedral olivine, clinopyroxene, and sparse chromite in a matrix of overgrown olivine and clinopyroxene and locally plagioclase. Olivine variably fractured. Locally intensely altered with olivine replaced by serpentine and magnetite; clinopyroxene by actinolite and chlorite; and plagioclase by very-fine-grained epidote and white mica.

Kppc PYROXENE-PLAGIOCLASE CUMULATE (Late Triassic[?]) — Chiefly composed of fine- to medium-grained aggregates of euhedral to subhedral clinopyroxene, plagioclase, and sparse chromite in a matrix of overgrown clinopyroxene or plagioclase. Local minor orthopyroxene.

Locally intensely metamorphosed to lower greenschist facies exhibiting granoblastic texture. Diagnostic minerals are chlorite, epidote, actinolite, white mica, and calcite. Locally weakly schistose. Most of unit occurs in Tangle subterrane, in vicinity of Fish Lake in central Mount Hayes Quadrangle. Intrudes Nikolai Greenstone and older rocks in both Slana River and Tangle subterranes. Interpreted as comagmatic with magmas that formed Nikolai Greenstone (Nokleberg and others, 1985).

\section{SLANA RIVER SUBTERRANE - SOUTH OF BROXSON GULCH THRUST AND DENALI FAULT AND NORTH OF EUREKA CREEK FAULT}

Slana River subterrane (Nokleberg and others, 1982, 1985) consists mainly of: (1) late Paleozoic marine volcanic and sedimentary rocks; (2) associated late Paleozoic hypabyssal and plutonic rocks; (3) disconformably overlying massive basalt flows of Triassic Nikolai Greenstone; and (4) coeval gabbro and cumulate mafic and ultramafic rocks, Triassic limestone, and younger Mesozoic flysch. 
KJS MARINE METASEDIMENTARY ROCKS (Early Cretaceous and Late Jurassic) —Principally deep-marine turbidite deposits consisting of graded beds of metamorphosed dark gray to gray argillite, siltstone, and graywacke that locally alternate with beds of massive graywacke, pebbly graywacke, pebble to cobble conglomerate, and sparse andesite. Graded beds well developed locally; consist of rhythmically alternating units that range from $1 \mathrm{~cm}$ to more than $30 \mathrm{~cm}$ in thickness. Massive graywacke and conglomerate beds up to $20 \mathrm{~m}$ thick. Thickness probably greater than 1,000 m; top not exposed. Occurs mainly in southeastern Mount Hayes Quadrangle and northwestern Nabesna Quadrangle.

Argillite composed of fine-grained, relict quartz and plagioclase clasts in matrix of chlorite and white mica. Minor minerals are epidote-clinozoisite, calcite, and sparse biotite. Millimeter-scale bedding defined by graphite-rich layers. Incipient schistosity defined by preferred orientation of sericite and by elongation of quartz and plagioclase grains. Argillite grades to schist adjacent to Chistochina Glacier. Schist composed of metamorphic quartz, chlorite, epidote, fibrous amphibole, and minor calcite.

Boulder to cobble, and pebble conglomerates composed chiefly of granitic clasts in a matrix of sand-sized schist, slate, quartz, and local plagioclase and interstitial chlorite. Quartz grains partially recrystallized. Sandstone composed of relict clastic quartz and plagioclase grains. Plagioclase partially replaced by white mica and epidote. Matrix generally consists of variable proportions of very-fine-grained schistose aggregates of chlorite, epidote, sericite, quartz, calcite, and opaque minerals. Andesite exhibits relict ophitic texture; mainly plagioclase microlites in groundmass of chlorite and minor white mica.

Unit locally intensely faulted and isoclinally folded. Local weak to moderately developed schistosity. Metamorphosed to lower greenschist facies. Diagnostic minerals are chlorite, epidote, white mica, actinolite, and calcite.

Unit occurs in eastern part of Mount Hayes Quadrangle along a 2- to 4-km-wide band south of, and adjacent to, Denali fault. Unconformably overlies Upper Triassic limestone and Nikolai Greenstone. Locally faulted along margins. Forms northwestern part of a thick sequence of flysch and associated rocks of Gravina-Nutzotin belt, which extends several thousand kilometers to the southeast (Berg and others, 1972; Monger and Berg, 1987). One locality in southeastern part of quadrangle yields Late Jurassic megafossils (table 1 of Nokleberg and others [1992a], locality 77). In Nabesna Quadrangle to the southeast, unit contains locally abundant Buchia assemblages ranging in age from Late Jurassic to Early Cretaceous (Richter, 1976).

Kl LIMESTONE (Late Triassic) — Chiefly dark to light gray micrite, dismicrite, or microsparite. Conformably overlies Nikolai Greenstone ( $\mathrm{kn}$ ). Fine to medium grained, medium to massive bedded $(10 \mathrm{~cm}$ to $2 \mathrm{~m})$, containing lenses and nodules of gray and black chert and irregular patchworks of disseminated fine-grained quartz. Locally recrystallized, commonly brecciated, and veined by coarsely crystalline calcite. Basal part of unit generally contains clasts of Nikolai Greenstone. Many outcrops too small to depict on map. Thickness approximately 20 to $150 \mathrm{~m}$.

Generally metamorphosed to lower greenschist facies; locally weakly schistose. Unit often occurs in narrow, faultenclosed lenses and slivers in subjacent Nikolai Greenstone in southeastern Mount Hayes Quadrangle. Locally contains moderately abundant Late Triassic megafossils and microfossils (table 1 of Nokleberg and others [1992a], localities 78, 79, 111-119).

kn NIKOLAI GREENSTONE (Late to Middle Triassic) (Rohn, 1900)—Similar to Nikolai Greenstone in Tangle subterrane (described below), but thinner. Chiefly massive dark gray-green, dark gray-brown, reddish brown, and maroon-gray subaerial, amygdaloidal basalt flows separated locally by thin beds of reddish brown nonmarine volcaniclastic rocks. Defined predominantly from intermixed 'a'a and pahoehoe flows with individual flow units ranging from a few centimeters to more than $15 \mathrm{~m}$ thick. Base generally marked by discontinuous conglomerate-breccia, with fragments of basalt, and underlying sedimentary rocks. Shale and chert are interlayered with greenstone in sparse exposures in south-central Mount Hayes Quadrangle. Chiefly interbedded black carbonaceous shale, gray, thin-bedded argillite, light-colored chert, and light-gray limestone with minor gray siltstone and conglomerate (Richter and others, 1977). Approximately 1,500 m thick.

Common relict igneous textures in greenstones, generally fine-grained ophitic to intergranular, locally grading to porphyritic, and glomeroporphyritic with a felty groundmass of plagioclase microlites. Relict igneous minerals are clinopyroxene, plagioclase, and magnetite and very sparse olivine. Local undulose extinction in plagioclase and clinopyroxene. Locally resorbed plagioclase. Amygdules up to $6 \mathrm{~mm}$ across filled by calcite, chlorite, epidote, quartz, and/or zeolite.

Unit pervasively metamorphosed to lower greenschist facies. Metamorphic minerals are chlorite, epidote, quartz, sericite, calcite, and actinolite. Clinopyroxene partially replaced by actinolite, epidote, and chlorite; plagioclase by 
epidote, sericite, and chlorite. Olivine partially serpentinized. Rare metamorphic prehnite and pumpellyite. Locally weakly schistose; sparse quartz veins. Local abundant pervasive epidote and chlorite alteration associated with regional metamorphism. Amygdules filled by chalcopyrite, bornite, malachite, and/or azurite in areas of pervasive epidote-chlorite alteration.

Unit widely distributed between Denali and Eureka Creek faults in south-central and southeastern Mount Hayes Quadrangle. Disconformably overlies Eagle Creek Formation; overlain by Upper Triassic limestone. Contains Middle or Late Triassic fossils in Tangle subterrane, described below. In southeastern Mount Hayes Quadrangle, unit locally composed of Middle Triassic shale, limestone, and chert, up to $40 \mathrm{~m}$ thick (Richter and others, 1977), too small to depict on map.

\section{Eagle Creek Formation (Early Permian) (Richter and Dutro, 1975)}

Occurs in southeastern and south-central Mount Hayes Quadrangle. Disconformably overlies Slana Spur Formation. Abundant mega- and microfossils, mainly brachiopods, corals, and foraminifers, indicating an Early Permian age (table 1 of Nokleberg and others [1992a], localities 17-51,73-74, 80-84, 87-94, 96-106, 109-110). Correlative with limestone of Hasen Creek Formation of Skolai Group in southern Wrangell Mountains (MacKevett, 1978).

Chiefly conformable sequence of alternating marine argillite and limestone. South-central Mount Hayes Quadrangle, east of Gulkana Glacier, consists of a lower limestone member composed of calcilutite, calcarenite, and calcirudite, and an upper member of argillite (Bond, 1976). Bioclastic material composed of a heterogeneous mixture of coral, bryozoan, brachiopod, echinoid, crinoid, fusulinid, and algal(?) fragments (Bond, 1976; Richter and Dutro, 1975). Fine to medium grained; thin to medium bedded; local planar cross-bedding in limestone. Limestones deposited in shallow water at or near wave base (Bond, 1976). Upper part of unit grades into thin (less than $40 \mathrm{~m}$ thick) radiolarian chert, shale, and limestone (Richter and others, 1977) of Permian age (N.J. Silberling, written commun., 1981). In eastern Mount Hayes Quadrangle, formation is differentiated into two limestone and two argillite members, described below (Richter and others, 1977). Disconformably overlain by Nikolai Greenstone; conformably overlies Slana Spur Formation. Thickness approximately $900 \mathrm{~m}$. In southeastern Mount Hayes Quadrangle, subdivided by Richter and others (1977) into four members:

Peua UPPER ARGILLITE MEMBER, chiefly thin bedded and dark gray with thin lenses and laminae of gray siltstone and minor bioclastic limestone, calcareous siltstone, and pyritic sandstone. Locally contains a thin $(0-40 \mathrm{~m})$ upper unit of shale, limestone, and chert. Thickness about $125 \mathrm{~m}$.

Peul UPPER LIMESTONE MEMBER, chiefly thin bedded, gray, and siliceous. Locally weathers ocherous yelloworange. Contains thin argillite interbeds and discontinuous lenses of massive light-gray-weathering limestone as thick as $50 \mathrm{~m}$. Argillite content increases in lower part of member. Locally metamorphosed to a conspicuous white, crystalline, granoblastic marble. Thickness probably ranges between 75 and $150 \mathrm{~m}$.

Pela LOWER ARGILLITE MEMBER, chiefly thin bedded, dark gray, shaley argillite, and gray-green, locally calcareous siltstones. Also contains subordinate dark gray bioclastic limestone (bryozoan biostromes), and thin-bedded gray limestone. Gray limestone increases in abundance in upper part of member, forming a ribboned unit that grades into limestone-argillite beds of upper limestone member. Locally cut by a number of irregular intrusive masses, dikes, and sills of equigranular gabbro and porphyritic diorite. Thickness approximately $400 \mathrm{~m}$.

Pell LOWER LIMESTONE MEMBER, chiefly massive- to thin-bedded gray limestone. Locally contains nodules and lenses of black and light-gray chert. Also contains subordinate beds of dark-gray calcareous, volcanic graywacke, sandstone, and siltstone, and clastic limestone. Clastic beds generally graded and locally cross bedded. Gabbro sills, some as thick as $25 \mathrm{~m}$, relatively numerous. Thickness approximately $275 \mathrm{~m}$.

Pea ARGILLITE UNIT, NOT SUBDIVIDED. Chiefly relict clastic quartz, lesser plagioclase, and sparse hornblende in a recrystallized, variable matrix of chlorite, epidote-clinozoisite, sericite, actinolite, sphene, opaque minerals, and sparse biotite and garnet. Schistose argillite defined by alignment of sericite and elongate mineral grains.

Pel LIMESTONE UNIT, NOT SUBDIVIDED. Chiefly detrital calcite with lesser quartz and plagioclase. Metamorphic minerals are chlorite, sericite, white mica, zeolites, and opaque minerals. Locally recrystallized calcite. Local bioclastic material replaced by zeolites.

Unit also contains local calcareous volcanic graywacke composed mainly of relict clasts of carbonate, twinned and zoned plagioclase, and sparse $\mathrm{K}$-feldspar and quartz, up to $2 \mathrm{~mm}$, in a recrystallized matrix of very-fine-grained carbonate, epidote, white mica, chlorite, opaque minerals, and clay(?) minerals. Local fractures filled by iron oxide, carbonate, and zeolites. 
Unit also contains local volcanic sandstone composed mainly of rounded to subangular relict clasts of twinned plagioclase and minor quartz in a recrystallized matrix of chlorite, carbonate, and lesser white mica, epidote, and opaque minerals.

Unit also contains local weakly schistose siltstone composed mainly of equidimensional to slightly elongate quartz porphyroclasts up to $0.6 \mathrm{~mm}$ long in matrix of aligned white mica, fine opaque stringers, and lenticular patches of chlorite and white mica. Minor minerals are epidote-clinozoisite, actinolite, biotite, and garnet.

Unit weakly metamorphosed mainly to greenschist facies. Diagnostic minerals are chlorite, epidote-clinozoisite, actinolite, white mica, and sparse biotite and garnet. Plagioclase partially replaced by white mica, saussurite, epidote-clinozoisite, and clay minerals; hornblende by chlorite and actinolite; biotite by chlorite.

Pi SHALLOW-LEVEL INTRUSIVE STOCKS, DIKES, SILLS, AND SMALL PLUTONS (Early Permian[?])—Sparse to locally abundant andesite, and lesser dacite and rhyolite, stocks, sills, and dikes that intrude Slana Spur Formation and Tetelna Volcanics. Unit occurs mainly in south-central and southeastern Mount Hayes Quadrangle. Only larger bodies are shown on geologic map.

Medium-gray, fine- to medium-grained dacite porphyry composed of euhedral to anhedral, variably resorbed quartz phenocrysts, up to $5 \mathrm{~mm}$ across, twinned and zoned plagioclase, and minor K-feldspar phenocrysts and glomerocrysts, up to $3 \mathrm{~mm}$ across, in very-fine-grained groundmass composed predominantly of granoblastic quartz and feldspar. Weathers pale yellow.

Dark gray-green andesite porphyry composed of locally abundant twinned and zoned plagioclase phenocrysts and glomerocrysts up to $5 \mathrm{~mm}$ long, and local relict hornblende phenocrysts up to $2 \mathrm{~mm}$ long, in a groundmass composed predominantly of chlorite and locally sparse to felty plagioclase microlites, which weathers orange. Minor minerals are quartz, biotite, opaque minerals, and rare clinopyroxene. Local relict hypautomorphic-granular texture. Sparse amygdules filled with calcite, chlorite, and quartz.

Granoblastic overprint metamorphic texture with local weak schistosity. Metamorphosed to lower greenschist facies. Diagnostic minerals are chlorite, epidote-clinozoisite, actinolite, sericite, and calcite. Plagioclase partially replaced by variable combinations of saussurite, sericite, epidote-clinozoisite, and calcite; K-feldspar by sericite, epidote-clinozoisite and calcite; hornblende by chlorite and actinolite; biotite by chlor-ite; clinopyroxene by chlorite and epidote-clinozoisite.

Locally intensely, hydrothermally altered to very-fine-grained aggregates of sericite, chlorite, epidote, actinolite, albite, potassium feldspar, montmorillonite, kaolinite(?), and calcite. Local disseminated sulfide minerals and sparse quartz-sulfide mineral veins. Sulfide minerals are pyrite, chalcopyrite, and sphalerite. Local intense iron staining from weathering of accessory iron-sulfide minerals.

Shallow-level intrusive rocks occur in Slana Spur Formation and Tetelna Volcanics, but not in younger, Early Permian Eagle Creek Formation; interpreted as comagmatic with volcanic rocks of Slana Spur Formation and of Early Permian(?) age.

\section{AHTELL PLUTON}

The late Paleozoic Ahtell pluton, along with relatively slightly older volcanic and associated sedimentary in Wrangellia terrane, are part of Skolai arc (Richter, 1966, 1976) that is discontinuously exposed in Wrangellia and Alexander terranes (fig. 1) and in adjacent parts of Canada to the east. The plutonic part of this arc consists of a suite of compositionally diverse Early to Middle Pennsylvanian granitic plutons grouped under the name "Ahtell pluton," which also includes a dioritegabbro-tonalite-anorthosite suite and diorite complex. U-Pb zircon ages of 290 to $316 \mathrm{Ma}$ (Barker and Stern, 1986). Plutonic complex contains early to middle Paleozoic(?) roof pendants of quartz-feldspar schist.

PPfg FINE-GRAINED BIOTITE GRANITE (Middle to Early Pennsylvanian)—Occurs in southeastern Gulkana D-1 Quadrangle and consists of fine-grained intrusions of biotite granite to quartz monzonite, tonalite, and minor quartz diorite. Locally metamorphosed at greenschist facies. Textures are anhedral to subhedral granular, porphyritic, and glomeroporphyritic. Generally weather white-gray to gray and slightly pink. Margins are altered and contain associated andesite porphyry dikes. Intruded by Triassic gabbro ( $\mathrm{kg}$ ) dikes. Phyllic alteration occurs locally, and pyrite is disseminated in local quartz veinlets up to $6 \mathrm{~cm}$ wide; minor molybdenum in veinlet walls. Major primary minerals are K-feldspar, quartz, biotite, and plagioclase. Accessory minerals are apatite, hornblende, zircon, sphene, and opaques. Chlorite, sericite, epidote, zoisite, saussurite, calcite, and actinolite are replacement miner- 
als. Plagioclase defines complicated twinning and normal and oscillatory zoning. Composition ranges from $\mathrm{An}_{26}$ to $\mathrm{An}_{32}$. Phyric plagioclase up to $2.5 \mathrm{~cm}$ long occurs in glomeroporphyritic clusters, and displays rare synneusis. Quartz commonly occurs as interstitial grains. Plagioclase is extensively altered to saussurite, sericite, and epidote. Biotite is altered to chlorite. Hornblende is replaced by chlorite. Subgrains of quartz are present, and some grains are fractured and broken.

PPpg PORPHYRITIC HORNBLENDE GRANODIORITE (Middle to Early Pennsylvanian) — Consists of medium- to coarse-grained, porphyritic hornblende quartz monzonite, and granite to granodiorite. Weathers gray to pink-gray and is leucocratic. Textures are anhedral to subhedral granular, porphyritic and glomeroporphyritic. Major primary minerals are plagioclase, hornblende, orthoclase, and quartz. Biotite, clinopyroxene, and opaques are primary accessory minerals. Replacement minerals are saussurite, sericite, chlorite, actinolite, and epidote. Hornblende is replaced by chlorite and actinolite. Biotite is replaced by chlorite. Plagioclase is altered to saussurite and sericite. Rare clinopyroxene is replaced by hornblende. Some grains are fractured and bent.

PPg BIOTITE-HORNBLENDE GRANITE AND AND LESSER GRANODIORITE (Middle to Early Pennsylvanian) - Occurs in Gulkana D-1 and northern C-1 quadrangles. Consists of biotite-hornblende granite and lesser granodiorite, minor clinopyroxene-biotite quartz monzonite to monzonite porphyry and hornblende quartz diorite. Locally metamorphosed at greenschist facies. Intrudes Tetelna Volcanics and diorite complex. Intruded by Triassic (Trg) and Tertiary ( $\mathrm{Tl})$ dikes. Massive, generally medium to coarse grained, weathers light gray to gray, and is commonly iron stained. Textures include anhedral to subhedral granular, porphyritic and glomeroporphyritic, and rare subophitic. Myrmekitic, perthitic, and graphitic textures occur locally. Minor K-feldspar phenocrysts up to $6 \mathrm{~cm}$ are present and enclose plagioclase, quartz, biotite, and hornblende. Biotite and hornblende preferentially occur in glomeroporphyritic clusters. Major primary minerals are plagioclase, orthoclase, quartz, hornblende, and biotite. Accessory minerals are opaques, zircon, apatite, sphene, and clinopyroxene. Replacement minerals are sericite, actinolite, chlorite, and saussurite. Secondary minerals are calcite and epidote. Plagioclase displays complicated twinning and normal and oscillatory zoning. Composition ranges from $\mathrm{An}_{26} \mathrm{to}_{\mathrm{An}}$ and averages $\mathrm{An}_{35}$. Plagioclase is extensively altered to saussurite and sericite. Hornblende is altered to chlorite and rare actinolite. Biotite is locally replaced by chlorite. Rare clinopyroxene is replaced by hornblende and minor chlorite. Calcite and epidote typically occur in veins. Plagioclase, orthoclase, and clinopyroxene are locally strongly undulose, and are locally fractured. Biotite is rarely fractured and bent, but displays erratic extinction. Clinopyroxene is twinned and displays some kink banding. On strike northwest in Mount Hayes Quadrangle, an isolated exposure of unit is dated at $311 \mathrm{Ma}$ by U-Pb isotopic studies (Aleinikoff and others, 1987).

PPgd BIOTITE-HORNBLENDE GRANODIORITE (Middle to Early Pennsylvanian) — Occurs in Gulkana D-1 Quadrangle and consists of biotite-hornblende granodiorite. Locally metamorphosed at greenschist facies. Intrudes Tetelna Volcanics and diorite complex; is intruded by Triassic ( $\mathrm{kg}$ ) and Tertiary ( $\mathrm{Tl}$ ) dikes. Massive, generally medium to coarse grained, weathers light gray to gray, and is commonly iron stained. Textures include anhedral to subhedral granular, and porphyritic. Major primary minerals are plagioclase, orthoclase, quartz, hornblende, and biotite. Accessory minerals are opaques, zircon, apatite, sphene, and clinopyroxene. Replacement minerals are sericite, actinolite, chlorite, and saussurite. Secondary minerals are calcite and epidote. Plagioclase displays complicated twinning and normal and oscillatory zoning. Composition ranges from $\mathrm{An}_{26} \operatorname{to}_{44} \mathrm{An}_{44}$ and averages $\mathrm{An}_{35}$. Plagioclase is extensively altered to saussurite and sericite. Hornblende is altered to chlorite and, rarely, actinolite. Biotite is locally replaced by chlorite. Rarely, clinopyroxene is replaced by hornblende and minor chlorite. Calcite and epidote typically occur in veins.

PPad ALTERED DIABASE AND GABBRONORITE (Middle to Early Pennsylvanian) — Occurs in northeast Gulkana D-1 and western Nabesna D-6 quadrangles. Consists of altered hornblende gabbronorite and diabase with lesser quartz diorite and hornblende quartz monzodiorite to monzonite. Metamorphosed at greenschist facies. Intrudes other diorite complex (PPd). Intruded by lamprophyre dikes (Tl). Displays prominent iron staining.

Gabbronorites and diabases are massive, green to dark green, and medium to coarse grained. Textures are ophitic to subophitic and subhedral granular. Plagioclase and hornblende are primary minerals. Primary accessory minerals are clinopyroxene, opaques, and quartz. Replacement minerals are tremolite, epidote, actinolite, chlorite, saussurite, and sericite. Rarely, plagioclase synneusis occurs, and clinopyroxene locally encloses plagioclase. Plagioclase displays normal and oscillatory zoning and complicated twinning. Composition of plagioclase averages $\mathrm{An}_{40}$. Low An content is due to replacement of plagioclase cores by saussurite and sericite. Plagioclase is extensively replaced by sericite and saussurite. Clinopyroxene is replaced by chlorite. Hornblende is altered to actinolite and chlorite. Rare quartz subgrains occur. Fractures occur in a few places. 
Quartz diorites and hornblende quartz monzodiorites and monzonites are green to gray-green, and fine to medium grained. Texture is anhedral to subhedral granular. Potassium feldspar and quartz are interstitial. Major primary minerals are plagioclase, quartz, hornblende, and orthoclase. Accessory minerals are opaques, biotite, clinopyroxene, zircon, and apatite. Replacement minerals include chlorite, saussurite, sericite, and calcite. Plagioclase synneusis occurs locally. Plagioclase displays normal zoning and complicated twinning. Composition is $\mathrm{An}_{32}$ to $\mathrm{An}_{38}$. Poikilitic orthoclase encloses plagioclase, biotite, and quartz. Clinopyroxene is replaced by hornblende. Plagioclase is altered to saussurite and sericite. Chlorite replaces hornblende. Calcite typically occurs in veins. Fractures occur locally.

PPdg DIORITE AND LESSER GRANODIORITE (Middle to Early Pennsylvanian)—Occurs in Gulkana D-1 and northern C-1 quadrangles. Includes hornblende-biotite diorite, hornblende diorite, and quartz diorite and rare hornblende quartz monzonite. Locally metamorphosed to greenschist facies. Intrudes Tetelna Volcanics $(\mathbb{P t})$. Intruded by Triassic ( $\mathrm{kg}$ ) and Tertiary (Tl) dikes, and Ahtell pluton. Locally metamorphosed at greenschist facies. Typically weathers rusty brown, and locally iron stained. On strike to east, this unit is dated by $\mathrm{U}-\mathrm{Pb}$ zircon isotopic studies as 295 to $319 \mathrm{Ma}$ (Barker and Stern, 1986).

Hornblende-biotite diorites, hornblende diorites, quartz diorites, and rare hornblende quartz monzonites are schistose, dark green to dark gray-green, and medium to coarse grained. They typically weather red-brown. Generally anhedral to subhedral granular with local myrmekitic texture; quartz is interstitial. Major primary minerals are plagioclase, hornblende, quartz, and biotite. Accessory minerals are orthoclase, opaques, clinopyroxene, apatite, and zircon. Replacement minerals are epidote, saussurite, calcite, tremolite, actinolite, and sericite. Plagioclase displays oscillatory and normal zoning. Composition ranges from $\mathrm{An}_{31}$ to $\mathrm{An}_{45}$. Hornblende is extensively altered to actinolite and chlorite. Biotite is replaced by chlorite. Plagioclase is highly altered to saussurite. Rare clinopyroxene is altered to hornblende. Fractured grains and epidote and calcite veins are common. Chlorite displays anomalous blue extinctions.

PPd DIORITE AND LESSER GRANODIORITE, AND GABBRONORITE (Middle to Early Pennsylvanian)—Occurs in Gulkana D-1 Quadrangle. Includes hornblende diorite and quartz diorite and rare hornblende quartz monzonite, clinopyroxene-hornblende gabbronorite, hornblende gabbro, and lesser clinopyroxene monzodiorite to granodiorite, diorite and rare tonalite. Locally metamorphosed to greenschist facies. Intrudes Tetelna Volcanics $(\mathbb{P t})$. Intruded by Triassic ( $\mathrm{kg}$ ) and Tertiary (Tl) dikes, and Ahtell pluton. Typically weather rusty brown, and are locally iron stained.

Hornblende-biotite diorites, hornblende diorites, and quartz diorites are schistose, dark green to dark gray-green, and medium to coarse grained. Typically weather red-brown. Generally anhedral to subhedral granular with local myrmekitic texture; quartz is interstitial. Major primary minerals are plagioclase, hornblende, quartz and biotite. Accessory minerals are orthoclase, opaques, clinopyroxene, apatite, and zircon. Replacement minerals are epidote, saussurite, calcite, tremolite, actinolite, and sericite. Plagioclase displays oscillatory and normal zoning. Composition ranges from $\mathrm{An}_{31}$ to $\mathrm{An}_{45}$. Hornblende is extensively altered to actinolite and chlorite. Biotite is replaced by chlorite. Plagioclase is highly altered to saussurite. Rare clinopyroxene is altered to hornblende. Fractured grains and epidote and calcite veins are common. Chlorite displays anomalous blue extinctions.

Clinopyroxene-hornblende gabbronorites are green to dark green, and generally fine to medium grained. Textures include subophitic to ophitic, porphyritic, and glomeroporphyritic. Plagioclase, hornblende, and clinopyroxene are primary minerals. Opaques are accessory minerals. Abundant actinolite, chlorite, sericite, saussurite, and epidote are replacement minerals. Minor plagioclase synneusis occurs. Plagioclase displays oscillatory and normal zoning and complicated twinning. Composition ranges from $\mathrm{An}_{58}$ to $\mathrm{An}_{68}$. Plagioclase is replaced by saussurite, sericite, and, rarely, epidote. Hornblende is replaced by actinolite and chlorite. Clinopyroxene is altered to chlorite. Minor fracturing is also present. Hornblende and clinopyroxene are twinned, and locally display kink banding.

Hornblende gabbros are fine to coarse grained and green to gray-green. Textures are mainly ophitic, subhedral to euhedral granular, locally glomeroporphyritic and porphyritic, and cryptocrystalline to microcrystalline. Major primary minerals are plagioclase and hornblende. Accessory primary minerals include clinopyroxene and opaques. Saussurite, sericite, and chlorite are replacement minerals. Plagioclase displays complicated twinning and oscillatory zoning. Composition is variable, but generally ranges from $\mathrm{An}_{28}$ to $\mathrm{An}_{35}$. Hornblende poikilitically encloses plagioclase. Hornblende is replaced by actinolite and chlorite. Clinopyroxene is replaced rarely by hornblende and chlorite. Plagioclase is altered to sericite and saussurite. Minor fractured grains also occur.

Clinopyroxene monzodiorites to granodiorites, diorites and rare tonalites occur locally in Gulkana D-1 Quadrangle. They are fine to coarse grained, but generally medium grained. Granodiorites are pink-gray, rare tonalites are 
white-gray, and monzodiorites and diorites are dark green to dark gray. Local shear zones contain abundant quartz and disseminated pyrite veins up to $13 \mathrm{~cm}$ wide. Textures are mainly porphyritic and subhedral granular with local subophitic to ophitic and glomeroporphyritic clots of plagioclase and clinopyroxene. Quartz and K-feldspar are interstitial. Euhedral plagioclase displays complicated twinning and normal and oscillatory zoning. Plagioclase is locally included in twinned clinopyroxene, and displays some synneusis. Composition ranges from $\mathrm{An}_{30}$ to $\mathrm{An}_{40}$. Primary minerals are plagioclase, clinopyroxene, and orthoclase. Accessory minerals are opaques, apatite, quartz, biotite, and hornblende. Replacement minerals are chlorite, epidote, actinolite, sericite, and actinolite. Plagioclase is extensively replaced by saussurite and sericite. Hornblende is extensively altered by chlorite and actinolite. Minor clinopyroxene is replaced by chlorite and, rarely, hornblende. Chlorite replaces biotite in a few places. Clinopyroxene displays some kink banding. Quartz subgrains are also present.

PPg GRANITIC PLUTONS (Pennsylvanian) (south of Denali fault in Gulkana D-1 Quadrangle) —Chiefly granite. Generally medium grained, hypautomorphic-granular texture, locally porphyritic. Composed of euhedral to subhedral phenocrysts of K-feldspar up to $5 \mathrm{~mm}$, with sparse inclusions of plagioclase and biotite, in a groundmass of quartz, K-feldspar, plagioclase, biotite, sparse opaque minerals, and rare zircon. Slight alteration of plagioclase to sericite; biotite to chlorite. Complex twinning and zoning in plagioclase and moderately undulose quartz. Metamorphosed to lower greenschist facies; diagnostic minerals are chlorite, actinolite, and sericite. Occurs in isolated outcrops west of Chistochina River in Mount Hayes A-2 Quadrangle.

$\mathrm{U}-\mathrm{Pb}$ zircon isotopic analysis yields an age of $309 \mathrm{Ma}$ (table 2 of Nokleberg and others [1992a], locality 79); interpreted as intrusive age. Unit probably a northwest extension of Pennsylvanian Ahtell pluton in northwestern Gulkana Quadrangle (Richter, 1966; Beard and Barker, 1989). K-Ar hornblende isotopic analysis of granodiorite at Rainbow Mountain in Mount Hayes B-4 Quadrangle yields a value of $326 \mathrm{Ma}$ (table 2 of Nokleberg and others [1992a], locality 76). This value, if correct, would be a Late Mississippian age, and would be older than surrounding wall rocks of Slana Spur Formation. However, the isotopic analysis may be erroneous, and the granitic pluton could be younger.

qfs QUARTZ-FELDSPAR SCHIST (middle to early Paleozoic[?]) — Quartz-feldspar schist with intense fabric, grading cataclasite. Exhibits intense deformational fabric with large, rotated and crushed feldspar and rare quartz crystals, in a fine-grained granoblastic matrix of quartz and minor porphyroblastic garnet with thin laminae of biotite or amphibole. Fabric is crosscut by non-deformed diorite, indicating that the schist is not simply intruded and metamorphosed late Paleozoic sedimentary and volcanic rock. Forms roof pendant in diorite complex of Richter (1976). Intruded by pluton of diorite and lesser granodiorite. Occurs in west-central Nabesna D-6 Quadrangle.

\section{Late Paleozoic stratified rocks of Slana River SUbterRane}

PPs SLANA SPUR FORMATION (Early Permian to Middle Pennsylvanian) (Unit of Richter and Dutro, 1975) Chiefly a thick sequence of marine calcareous and noncalcareous volcaniclastic rocks and lesser limestone, tuff, and volcanic breccia. Occurs in southeastern and south-central Mount Hayes Quadrangle. Ages of megafossils and microfossils in both members of formation, mainly brachiopods, corals, and foraminifers, range from Middle Pennsylvanian through Early Permian (table 1 of Nokleberg and others [1992a], localities 13-16, 52-57, 59-63, 65-69, 71-72, 76, 86, 107-108; and table 2, below). A K-Ar hornblende isotopic analysis of a weakly metamorphosed mafic nodule in Slana Spur Formation yields an age of $94.4 \mathrm{Ma}$ (table 2 of Nokleberg and others [1992a], locality 82), and may represent the age of low-grade regional metamorphism of Wrangellia terrane. Unit correlative with volcaniclastic member of Station Creek Formation of Skolai Group in southern Wrangell Mountains (MacKevett, 1978). Disconformably overlies Tetelna Volcanics. Chiefly andesite tuff, flows, and breccia, and volcanic-rich sedimentary rocks including mudstone, sandstone, graywacke, and conglomerate, and locally fossiliferous limestone. Thickness $700-1,400 \mathrm{~m}$.

Highly sheared adjacent to Broxson Gulch thrust. Generally weak granoblastic texture with locally weak schistosity. Lower greenschist-facies metamorphism defined by fine-grained granoblastic occurrence of chlorite, epidoteclinozoisite, actinolite, white mica, and calcite throughout unit. Plagioclase and K-feldspar partially replaced by white mica, epidote, saussurite, and calcite; hornblende by chlorite, epidote, and actinolite. Variably strained, fractured, and granulated quartz and feldspar and bent mica. Local relict hydrothermal alteration and iron staining adjacent to shallow-level intrusive rocks. Hydrothermal alteration defined by very-fine-grained aggregates of epidote, chlorite, actinolite, albite, K-feldspar, calcite, and sericite. Locally divided into:

PPsu CALCAREOUS VOLCANICLASTIC ROCKS MEMBER - Predominantly gray-green, clastic, locally fossiliferous limestone and marble, and gray-green, coarse-grained, calcareous volcanic sandstone. Includes minor volcanic 
conglomerate, light gray-green lapilli tuff, and andesite. Clastic rocks generally contain angular to subangular clasts, have abundant graded bedding, abundant contorted stratification, and slump structures; poorly sorted. Volcaniclastic rocks contain abundant andesitic, dacitic, and pumiceous rock fragments, with relict pyroclastic, pilotaxitic, trachytic, scoriaceous, and glassy textures. Thickness 350-450 m.

Limestone to marble composed of calcite with minor quartz, plagioclase, and sericite. Local skarn, developed in lenses up to $1 \mathrm{~m}$ thick along diabase-marble contact, composed of fine- to medium-grained schistose calcite and minor epidote, hornblende, wollastonite, garnet, and clinopyroxene.

Volcanic sandstone composed of fine-grained, rounded to subangular clasts of twinned and zoned plagioclase and minor quartz in matrix predominantly of chlorite. Authigenic analcite replaces and cements clasts in some calcareous sandstone.

Calcareous volcanic graywacke composed of abundant twinned and zoned plagioclase clasts up to $1.5 \mathrm{~mm}$ long in a fine-grained, sparsely fossiliferous matrix of calcite and minor epidote and white mica. Presence of graded bedding, poor sorting, and slump structures indicates sedimentary and volcaniclastic strata deposited from turbidity currents in a low-energy environment below wave base located near active volcanic vents (Bond, 1973, 1976).

Andesite has intergranular to ophitic porphyritic texture. Composed of twinned and zoned plagioclase phenocrysts locally resorbed and sparse glomerocrysts up to $3.5 \mathrm{~mm}$ long and local hornblende phenocrysts up to $2 \mathrm{~mm}$ long, in a fine-grained to felty groundmass of plagioclase, quartz, and white mica. Locally amygdules filled with clinozoisite and chlorite.

Andesite tuff composed of angular to subangular plagioclase fragments in matrix predominantly of clay minerals, opaque minerals, and locally abundant calcite. Hornblende(?) completely replaced by chlorite.

Diabase composed of fine-grained plagioclase and clinopyroxene and minor opaque minerals, chlorite, and epidote. Relict minerals are plagioclase and sparse hornblende, quartz, clinopyroxene, and opaque minerals. Metamorphic minerals are chlorite, epidote, calcite, and white mica.

Dacitic to rhyodacitic ash to lapilli tuffs, green to gray, mainly broken plagioclase, quartz, K-feldspar, and lithic fragments in matrix of very-fine-grained aggregate of quartz, feldspar, chlorite and local leucoxene. Plagioclase commonly twinned. Pumice fragments preserved as irregular platelets and disks of chlorite with porous or tubular texture. Lithic fragments angular; composed of a variety of volcanic rocks exhibiting porphyritic, trachytic, pilotaxitic, glassy, microvesicular, and scoriaceous textures. Locally stratified due to variation in grain size, color, and grading. Local normal and double grading. A 200-m-thick, unstratified lapilli tuff in northwest Mount Hayes A-3 Quadrangle exhibits distinctive large aerial extent, lack of K-feldspar, and coarse pumice fragments ranging from less than $1 \mathrm{~cm}$ to nearly $1 \mathrm{~m}$ long (Bond, 1976).

Green to grayish green debris-flow deposits composed of poorly sorted angular fragments, from 5 to $20 \mathrm{~cm}$ across and locally imbricate, in a matrix of sand, silt, and mud. Angular fragments composed of volcanic rock fragments, plagioclase, quartz, and fossil debris. Matrix mainly microcrystalline quartz, fine chlorite, and/or sericite, and leucoxene. Individual beds range in thickness from a few centimeters to about $18 \mathrm{~m}$. Upper parts of beds often graded, with thin, laminated tops (Bond, 1976).

Gray, brown, or green poorly sorted sandstone and graywacke beds, from $2 \mathrm{~cm}$ to more than $1 \mathrm{~m}$ thick; interbedded with subordinate, massive or laminated, silty claystones from a few centimeters to a few meters thick. Beds graded but lack internal current features such as crossbedding, convoluted bedding, parallel lamination, or ripple-drift lamination. Grain size ranges from pebbles to fine sand. Clasts mainly angular to subangular. Clasts composed of andesitic(?) fragments, plagioclase, and quartz. Volcanic rock fragments exhibit pyroclastic, pilotaxitic, trachytic, glassy, and sparse scoriaceous and pumiceous textures. Matrix chiefly a dark, microcrystalline aggregate of chlorite and leucoxene and minor amounts of quartz and feldspar (Bond, 1976).

Unit metamorphosed to lower greenschist facies. Well exposed in south-central and southeastern Mount Hayes Quadrangle, south of Denali fault and Broxson Gulch thrust, and north of Eureka Creek fault. Underlies Eagle Creek Formation. Overlies volcaniclastic rocks member (PPsl).

PPsl VOLCANICLASTIC ROCKS MEMBER—Dark gray, dark green, and maroon volcanic and volcaniclastic rocks. Chiefly volcanic flows interbedded with lapilli tuff, volcanic breccia, graywacke, argillite, and limestone to marble. Local massive to bedded conglomerate, graywacke, and siltstone. Volcaniclastic rocks contain abundant volcanic rock fragments and relict pumice, exhibiting trachytic, scoriaceous, and relict glassy textures. Limestone to marble 
lenses as thick as $25 \mathrm{~m}$, mainly gray, thin- to medium-bedded, locally volcanic-rich limestone. Local graded bedding in volcaniclastic rocks. Presence of graded bedding in volcaniclastic rocks and fossil fragments in volcanic breccias indicate volcaniclastic and volcanic rocks deposited on sea floor as blanket deposits around volcanic vents (Bond, 1973, 1976). Thickness 300-950 m.

Lapilli tuff composed of crystals and crystal fragments of quartz, plagioclase, and K-feldspar(?) up to $3 \mathrm{~mm}$ across, lithic volcanic rock fragments up to $9 \mathrm{~mm}$ across, and lesser microcrystalline quartz fragments. Matrix mainly chlorite and minor sericite, calcite, and opaque minerals.

Andesitic flows composed mainly of phenocrysts and sparse glomerocrysts of zoned and twinned plagioclase, up to $4 \mathrm{~mm}$ long, in groundmass of very-fine-grained quartz, chlorite, epidote, sericite, and opaque minerals. Volcanic textures range from hypautomorphic-granular to porphyritic. Sparse to abundant plagioclase microlites form local pilotaxitic to felty groundmass textures. Phenocrysts of hornblende and biotite up to $1 \mathrm{~mm}$ long occur locally. Quartz phenocrysts up to $6 \mathrm{~mm}$ across with resorbed outlines in dacite.

Basaltic flows composed of clinopyroxene and sparse hornblende phenocrysts up to $1.8 \mathrm{~mm}$ across, in trachytic groundmass of calcic plagioclase. Local amygdules filled with quartz and chlorite. Relict igneous minerals are plagioclase, hornblende, clinopyroxene, and biotite. Metamorphic minerals are quartz, chlorite, epidote, sericite, calcite, and opaque minerals.

Volcanic graywacke composed of rounded to subangular relict clastic plagioclase, quartz, and sparse K-feldspar in a very-fine-grained, largely recrystallized matrix of chlorite, feldspar, quartz, white mica, carbonate, and clay. Locally calcite rich. Local resorbed outlines on quartz clasts. Relict volcanic plagioclase commonly twinned and zoned.

Argillite composed of variable combinations of very-fine-grained, angular to subangular quartz, plagioclase, and $\mathrm{K}$-feldspar in a recrystallized matrix of calcite, white mica, chlorite, epidote, and opaque minerals. Locally abundant calcite veins. Weak schistosity defined by aligned mica and elongate opaque minerals.

Limestone composed of fine-grained calcite with minor quartz, white mica, chlorite, and opaque minerals. Locally grades into medium- to coarse-grained, light gray to white marble. Locally contains volcanic clasts up to $5 \mathrm{~mm}$ across, composed of quartz and plagioclase. Local carbonaceous coating on calcite grains. Local veins of coarsergrained calcite and sparse quartz. Locally metasomatized to sulfide-silicate skarn adjacent to shallow intrusive rocks. Local disseminations and pods of sulfide minerals, mainly pyrite, chalcopyrite, bornite, and sphalerite.

Unit metamorphosed to lower greenschist facies. Well exposed in south-central and southeastern Mount Hayes Quadrangle, south of Denali fault and Broxson Gulch thrust, and north of Eureka Creek fault. Overlies Tetelna Volcanics $(\mathbb{P t})$.

Pt TETELNA VOLCANICS (Pennsylvanian) (Unit of Mendenhall, 1905) — Chiefly dark green, dark gray-green, and purplish gray-green volcanic flows, mud and debris avalanches, locally graded, and lapilli-pumice tuffs interbedded with fine- to coarse-grained volcaniclastic rocks. Volcanic flows generally massive and porphyritic. Consist of hornblende andesite, hornblende andesite to dacite with rare andesite agglomerate, hornblende and biotite rhyodacite, and hornblende rhyodacite to dacite. Includes rhyolite and rhyodacite, hornblende-clinopyroxene dacite to rhyodacite flows and sparse dacite. Local hornblende-biotite andesite, andesite tuff, andesite volcaniclastics, volcanic graywackes, and agglomerates. Local clinopyroxene-hornblende basalts to rare andesites also occur. Unit contains local interlayered siltstone, limestone, sandstone, graywacke, and chert in narrow lenses (labeled with s). Intruded by associated granitic rocks of Ahtell pluton and diorite complex, Triassic gabbro ( $\mathrm{kg}$ ) and Tertiary lamprophyre (Tl) dikes. Thickness greater than 1,000 m. Base not exposed.

Volcanic flows, mainly andesite, composed of phenocrysts and glomerocrysts of twinned and zoned plagioclase and local hornblende, up to $4 \mathrm{~mm}$ long, in a fine-grained groundmass of chlorite, epidote, felty plagioclase microlites, and sparse microphenocrysts of clinopyroxene. Local amygdules filled with chlorite. Relict minerals are plagioclase, hornblende, clinopyroxene, and sparse quartz. Metamorphic minerals are quartz, actinolite, epidote-clinozoisite, sericite, calcite, and opaque minerals. Tuffs contain pumice and andesitic lithic fragments from millimeters to tens of centimeters across.

Andesite agglomerates are generally medium grained, weather dark green to green and dark gray, and contain sub-angular to angular clasts up to $6 \mathrm{~cm}$ long. Clasts are predominantly composed of chert with lesser volcanic mudflow fragments. Pyrite is present in iron-stained flows. Textures include porphyritic, pilotaxitic, and schistose. Plagioclase is primary mineral. Minor minerals are opaques, quartz, and hornblende. Replacement minerals are 
saussurite, chlorite, calcite, epidote, actinolite, and sericite. Plagioclase displays complicated twinning and normal and oscillatory zoning. Synneusis is locally present. Composition varies from $\mathrm{An}_{31}$ to $\mathrm{An}_{35}$. Plagioclase is extensively altered to saussurite and sericite. Hornblende is replaced by chlorite and actinolite. Subgrains of quartz are common. Metamorphosed at greenschist facies.

Hornblende and biotite rhyodacites are dark gray, fine to medium grained, and contain local interbedded chert and conglomerate. Minor disseminated sulfides are also present. Textures are porphyritic, glomeroporphyritic, subhedral granular, and schistose. Primary minerals are plagioclase, potassium feldspar, hornblende, quartz, and biotite. Opaques are accessory minerals. Replacement minerals are saussurite, chlorite, sericite, epidote, actinolite, and calcite. Plagioclase displays complicated twinning, normal and oscillatory zoning, and synneusis. Composition is $\mathrm{An}_{30}$ to $\mathrm{An}_{35}$. Quartz phenocrysts are typically embayed. Quartz also occurs in veins that are subparallel to subtle schistosity. K-feldspar occurs in groundmass. Plagioclase is extensively altered to saussurite, sericite, and calcite. Biotite is replaced by chlorite. Hornblende is replaced by chlorite, rarely calcite, and actinolite. Phenocrysts are fractured. Hornblende and biotite display kink bands in a few places. Metamorphosed at greenschist facies.

Sparse hornblende rhyodacites and lesser dacites are dark green to gray-green, and medium to fine grained. Textures are porphyritic, glomeroporphyritic, and schistose. Major primary minerals are plagioclase, orthoclase, and hornblende. Minor minerals are opaques, quartz, and biotite. Retrogressive minerals are calcite, chlorite, epidote, actinolite, and sericite. Plagioclase displays normal and oscillatory zoning. Composition ranges from $\mathrm{An}_{24}$ to $\mathrm{An}_{28}$. $\mathrm{K}$-feldspar occurs in groundmass. Hornblende poikilitically encloses plagioclase. Hornblende is replaced by chlorite, calcite, and actinolite. Plagioclase is altered to saussurite, chlorite, calcite, and sericite. Locally metamorphosed at greenschist facies.

Rhyodacites to rhyolites are massive, dark gray to gray, and medium to generally fine grained. They are locally iron stained. Textures are porphyritic, glomeroporphyritic, and schistose. Major primary minerals are plagioclase and orthoclase. Quartz and opaques are accessory minerals. Replacement minerals are epidote, sericite, saussurite, and chlorite. Plagioclase synneusis is locally present. Plagioclase displays oscillatory and normal zoning. Composition varies from $\mathrm{An}_{28}$ to $\mathrm{An}_{37}$. K-feldspar comprises most of groundmass. Plagioclase is extensively replaced by sericite and saussurite.

Hornblende-pyroxene dacite to rhyodacite flows occur in northern Gulkana C-1 and throughout Gulkana D-1 quadrangles. They are gray-green to gray and generally fine to medium grained. Iron stains and disseminated pyrite occur locally. Metamorphosed at greenschist facies. Textures include porphyritic, trachytic, glomeroporphyritic, felty, pilotaxitic, and schistose. Primary minerals are plagioclase, potassium feldspar, hornblende, and clinopyroxene. Minor minerals are opaques and quartz. Replacement minerals are epidote, actinolite, chlorite, calcite, sericite, and saussurite. Phenocrysts of hornblende, plagioclase, and clinopyroxene occur in a fine-grained groundmass composed predominantly of plagioclase microlites, potassium feldspar, and chlorite. Phyric plagioclase displays complicated twinning, oscillatory zoning, and rare synneusis. Composition generally averages $\mathrm{An}_{27}$. Sparse plagioclase occurs in glomeroporphyritic clots. Plagioclase is altered to sericite and saussurite. Hornblende is replaced by actinolite, chlorite, and minor calcite. Minor clinopyroxene is altered to chlorite and hornblende. Hornblende and pyroxene display kink banding and fractures.

Dacites occur mainly in Gulkana D-1 Quadrangle, and are gray to dark gray, and generally medium grained. They are locally iron stained, contain sparse disseminated sulfides, and are interbedded with minor argillite, quartzites, and calc-schists. Textures include schistose, glomeroporphyritic, porphyritic, felty, trachytic, and pilotaxitic. Rare amygdules are filled with chlorite and quartz. Quartz and plagioclase are primary minerals. Accessory minerals are hornblende and biotite. Replacement minerals are calcite, saussurite, actinolite, sericite, chlorite, and epidote. Microlites of plagioclase occur in randomly oriented flow patterns. Phyric plagioclase is resorbed with patchy zoning, and composition ranges from $\mathrm{An}_{36}$ to $\mathrm{An}_{41}$. Quartz phenocrysts are embayed. Minor biotite and hornblende are replaced by chlorite, and plagioclase is replaced by saussurite, sericite, and calcite. Plagioclase and quartz display minor fractures and strong undulatory extinction.

Hornblende-biotite andesite and andesite flows are dark green to dark gray-green, and fine to medium grained. Sparsely interbedded with medium-grained volcaniclastic flows and siltstone, and locally metamorphosed at lower greenschist facies. Textures are porphyritic, schistose, glomeroporphyritic, subophitic, felty, and pilotaxitic. A minor flow foliation is present. Major primary minerals are plagioclase, hornblende, and biotite. Quartz, olivine, clinopyroxene, and opaques are accessory minerals. Replacement minerals are epidote, actinolite, serpentine, sericite, calcite, and saussurite. Phyric quartz is embayed. Plagioclase displays oscillatory zoning and complicated twinning. Composition ranges from $\mathrm{An}_{30}$ to $\mathrm{An}_{35}$. Hornblende is replaced by chlorite and minor calcite. Plagioclase is extensively altered to sericite and saussurite. 
Interbedded siltstone is fine to medium grained, occurs in layers up to $125 \mathrm{~m}$ thick, and is sparsely interlayered with 4- to 15 -cm-thick rusty chert beds. Major minerals in siltstone beds are quartz, muscovite, and plagioclase. Chlorite and saussurite are replacement minerals. Opaque minerals are rare. Foliation is well developed, and elongate grains are also present.

Fine-grained andesite tuffs are massive and occur chiefly in Gulkana D-1 Quadrangle. They are locally subaqueous, interlayered with minor chert, silty sandstone, and limestone, and contain abundant disseminated sulfides, including pyrite and chalcopyrite. They are locally iron stained. Textures are porphyritic, glomeroporphyritic, pilotaxitic, felty, and schistose. Microlites of plagioclase occur in sub-parallel flows. Amygdules are filled with quartz, chlorite, actinolite, and rare relict hornblende. Plagioclase is primary mineral. Accessory minerals are opaques, quartz, and hornblende. Replacement minerals are epidote, chlorite, saussurite, and actinolite. Plagioclase displays complicated twinning, oscillatory zoning, and synneusis. Composition ranges from $\mathrm{An}_{34}$ to $\mathrm{An}_{40}$. Hornblende is extensively altered to actinolite and chlorite. Plagioclase is highly altered to saussurite and minor epidote. Foliation is locally well developed with stretched grains. Epidote occurs in abundant veins. Metamorphosed to lower greenschist facies.

Rare volcaniclastic andesites are dark green to dark gray, generally medium grained, contain angular to sub-angular grains, and are schistose. Relict quartz and calc-siltstone layers occur. Primary minerals are plagioclase and quartz. Opaques and relict hornblende occur rarely. Replacement minerals are chlorite, epidote, calcite, saussurite, and sericite. Plagioclase displays normal and oscillatory zoning. Composition generally ranges from $\mathrm{An}_{32}$ to $\mathrm{An}_{37}$. Some cores are as calcic as $\mathrm{An}_{60}$. Relict hornblende is replaced by chlorite. Plagioclase is extensively altered to saussurite, sericite, and calcite. Quartz is locally recrystallized.

Volcaniclastics, volcanic graywackes and agglomerates are interlayered with andesites, and are generally medium grained. Rare interbeds of siltstone, silty sandstone, chert, graywacke, and silty limestone also occur. Agglomerates contain sparse argillite fragments up to $3 \mathrm{~cm}$ long. Bedding is graded locally. Rare microlites of relict plagioclase are subparallel and define trachytic texture. Porphyritic textures occur rarely. Angular grains of undulose plagioclase and quartz occur in a groundmass composed predominantly of chlorite, actinolite, and epidote. Major minerals are plagioclase and quartz; accessory minerals are opaques and relict hornblende. Replacement minerals are epidote, chlorite, actinolite, saussurite, and sericite. Relict hornblende is highly altered to chlorite and actinolite. Plagioclase is extensively replaced by calcite, saussurite, and sericite. Fractured grains are common. Metamorphosed to lower greenschist facies.

Silty limestones contain quartz and calcite with accessory opaques, muscovite, zoisite, and chlorite. They are fine to medium grained. Quartz is typically fractured.

Clinopyroxene-hornblende basalts to minor andesites occur in the Gulkana D-1 Quadrangle. Mainly dark green, fine to medium grained, locally include argillite fragments, and interlayered with calcareous siltstone and limestone, volcaniclastic rocks, graywacke, rare chert, and agglomerate. Textures are porphyritic, felty, trachytic, and glomeroporphyritic. Plagioclase microlites locally define sub-pilotaxitic texture. Rare plagioclase is enclosed poikilitically in clinopyroxene. Plagioclase, hornblende, and clinopyroxene are primary minerals; opaques and rare quartz are accessory minerals. Replacement minerals are chlorite, epidote, actinolite, saussurite, and sericite. Plagioclase displays complicated twinning and normal zoning. Composition generally ranges from $\mathrm{An}_{54}$ to $\mathrm{An}_{60}$. Plagioclase synneusis occurs locally. Hornblende, plagioclase, and minor clinopyroxene occur in glomeroporphyritic clusters. Hornblende is nearly completely replaced by chlorite and sparse actinolite. Clinopyroxene is replaced by chlorite and rare hornblende. Plagioclase is altered to sericite and saussurite. Rare clinopyroxene and hornblende are undulose and display minor kink banding. Minor fracturing is present. Locally metamorphosed to lower greenschist facies.

Light tan to pink calcareous siltstones and white, fossiliferous limestones are locally interlayered, very fine grained, and contain rare calcite veins. Siltstone beds occur locally up to $125 \mathrm{~m}$ thick. Calcite is major mineral; quartz, muscovite, and opaques are accessory minerals. Volcaniclastic rocks consist of graywackes and agglomerates with minor cherts. Agglomerates contain rare argillite fragments up to $3 \mathrm{~cm}$ long. Typically schistose with some well-preserved bedding.

Unit metamorphosed to lower greenschist facies. Diagnostic minerals are chlorite, epidote-clinozoisite, actinolite, sericite, and calcite. Plagioclase replaced by epidote, sericite, calcite, and saussurite; hornblende by chlorite and actinolite; clinopyroxene by epidote and actinolite. Weak granoblastic metamorphic texture with variably strained and fractured quartz, plagioclase, hornblende, and clinopyroxene. 
Unit occurs mainly in southeastern corner of Mount Hayes Quadrangle in scattered outcrops up to $3 \mathrm{~km}$ across. Underlies Slana Spur Formation (PPsl). Interpreted to be of Pennsylvanian age because of position stratigraphically beneath, and containing volcanic rocks lithologically similar to, those in Slana Spur Formation (Richter, 1976; Richter and others, 1977). Correlative with volcanic flows member of Station Creek Formation of Skolai Group in southern Wrangell Mountains (MacKevett, 1978).

\section{TANGLE SUbTERRANe - SOUth OF EUREKA CREEK FAULt AND NORTH OF PAXSON LAKE FAULT}

Tangle subterrane (Nokleberg and others, 1981a,b; 1982, 1985) consists mainly of a relatively thin sequence of upper Paleozoic and Lower Triassic sedimentary and tuffaceous rocks, and a relatively thick sequence of unconformably overlying pillow basalt and subaerial basalt flows of Triassic Nikolai Greenstone and locally overlying limestone. Tangle subterrane includes Amphitheater Group of Smith (1974), Stout (1976), and Silberling and others (1981). Tangle subterrane occurs south of Eureka Creek fault and north of Paxson Lake fault in southeastern Mount Hayes Quadrangle and in western to central northern Gulkana Quadrangle.

k1 LIMESTONE (Late Triassic) —Fine to medium grained, medium to massive bedded. Generally composed of calcite clasts in a very-fine-grained matrix of calcite and minor quartz. Moderately to highly recrystallized. Locally weakly schistose. Contains irregular veins of fine-grained quartz. Commonly veined by coarsely crystalline calcite. Locally extensively metasomatized along veins to hedenbergite-garnet skarn. Major minerals in skarn are calcite, wollastonite, hedenbergite, and garnet; minor minerals are actinolite, plagioclase, and chlorite. Exposed in one locality, faulted against Nikolai Greenstone and unit grs3 in southwestern Mount Hayes Quadrangle. Maximum exposed thickness of several hundred meters.

Unit contains Late Triassic cephalopods and pelecypods (table 1 of Nokleberg and others [1992a], localities 120, 123). To the west in southeastern Healy Quadrangle, similar limestone layers in basal member of Nikolai Greenstone contain megafossils and microfossils also of Late Triassic age (Csejtey and others, 1992).

kn NIKOLAI GREENSTONE (Late or Middle Triassic) (Unit of Rohn, 1900)—Unconformably overlies aquagene tuff, argillite, limestone, chert, andesite tuff, and greenstone ( $\mathrm{kt}$ ). Divided into:

knf SUBAERIAL BASALT FLOWS MEMBER (Late or Middle Triassic)—Similar to Nikolai Greenstone in Slana River subterrane. Chiefly dark gray-green, gray, purple, black, or brown, massive amygdaloidal basalt flows lithologically similar to Nikolai Greenstone in Slana River subterrane. Fine to medium grained. Includes sparse basaltic breccia and basaltic aquagene tuff. Sparse limestone, siltstone, shale, and chert occur in south-central part of Mount Hayes Quadrangle, southeast of Summit Lake. As mapped, includes rocks assigned to Boulder Creek Volcanics and Paxson Mountain Basalt by Stout (1976). Maximum exposed stratigraphic thickness greater than $4,350 \mathrm{~m}$; top eroded.

Basalt flows composed of local phenocrysts and glomerocrysts of complexly twinned and zoned plagioclase, up to $7 \mathrm{~mm}$ long (average 1-2 $\mathrm{mm}$ ), in a relict ophitic to intergranular groundmass of plagioclase microlites, hornblende, clinopyroxene, ilmenite, magnetite, and very-fine-grained chlorite and opaque minerals. Local, very-fine-grained hematite or limonite in groundmass impart maroon color. Locally contains concentrically zoned amygdules filled with epidote, calcite, chlorite quartz, zeolites, and occasionally copper sulfides. Layers of amygdaloidal concentrations parallel primary layering. Amygdules locally stretched parallel to flow direction.

Unit metamorphosed to lower greenschist facies. Generally weak granoblastic texture superposed on relict ophitic, intergranular, and diabasic textures; locally schistose. Locally mylonitic. Variably fractured and granulated quartz and feldspar. Diagnostic metamorphic minerals are chlorite, epidote-clinozoisite, actinolite, white mica, and rare prehnite and pumpellyite. Plagioclase replaced by white mica, epidote, sericite, calcite, and saussurite; hornblende by chlorite and actinolite; clinopyroxene by chlorite, actinolite, and epidote. Sparse to locally abundant quartz veins up to $30 \mathrm{~m}$ thick, composed of minor chlorite, epidote-clinozoisite, calcite, pyrite, chalcopyrite, bornite, and malachite.

Unit well exposed in southwestern Mount Hayes Quadrangle. Faulted against Slana Spur Formation along Eureka Creek fault and against Maclaren Glacier metamorphic belt of Maclaren terrane along Broxson Gulch thrust.

Knp PILLOW BASALT FLOWS MEMBER - Chiefly interlayered dark gray-green pillow basalt flows, and minor basalt flow breccia, aquagene, and epiclastic tuff, breccia, argillite, and radiolarian chert; equivalent 
pillowed andesite flows form upper part of Tangle Lakes Formation of Stout (1976). Thickness about $1,020 \mathrm{~m}$.

Pillow basalts exhibit relict ophitic, subophitic, and intergranular textures. Locally porphyritic. Composed of relict plagioclase, hornblende, and clinopyroxene phenocrysts, $2-7 \mathrm{~mm}$ long, in chlorite-rich groundmass. Relict igneous minerals are plagioclase, hornblende, and clinopyroxene. Glassy pillow rims replaced by very-fine-grained chlorite, actinolite, plagioclase, and epidote. Plagioclase phenocrysts complexly twinned and zoned. Contains amygdules filled by calcite, chlorite, epidote, quartz, zeolites, and sparse copper sulfides. Sparse concentric zoning in amygdules.

Aquagene tuff composed of relict pillow rind fragments containing microlites of plagioclase and clinopyroxene. Glass-rich pillow rinds replaced by very-fine-grained chlorite, actinolite, feldspar, and epidote.

Epiclastic tuff composed of thin layers, 1-3 mm thick, of well sorted, very-fine-grained plagioclase and clinopyroxene, extensively replaced by epidote, chlorite, and actinolite.

Volcanic breccia, interbedded with finer-grained tuffs, composed of angular clasts in a light to dark green aphanitic matrix. Fragments, averaging several centimeters across and up to $1 \mathrm{~m}$ in diameter; composed of siliceous tuffs, andesite flow rocks, other breccias, and rare tuffaceous limestone (Stout, 1976).

Argillite composed of very-fine-grained schistose aggregates of plagioclase, calcite, graphite, and sparse chlorite, sericite, and opaque minerals. Locally finely laminated and calcite rich.

Gray radiolarian chert composed of granoblastic aggregates of very-fine-grained quartz and sparse sericite, chlorite, calcite, epidote, and opaque minerals and with very sparse highly recrystallized radiolaria.

Unit metamorphosed to lower greenschist facies. Generally weak granoblastic texture superposed on relict igneous textures; locally schistose. Variably fractured and granulated. Diagnostic minerals in mafic lithologies of chlorite, epidote-clinozoisite, actinolite, white mica, and graphite. Plagioclase partially replaced by epidote, saussurite, and white mica; hornblende and clinopyroxene by chlorite and actinolite.

Unit well exposed in southwestern Mount Hayes Quadrangle. Faulted against Slana River subterrane along Eureka Creek fault and against Maclaren Glacier metamorphic belt of Maclaren terrane along Broxson Gulch thrust. Underlies subaerial pillow basalt flows member (Knf).

Sparse layers and lenses of argillite form small hill; one locality yields very sparse Middle or Late Triassic Daonella or Halobia (table 1 of Nokleberg and others [1992a], locality 124). Late Triassic fossils occur in same unit to west in southeastern Healy Quadrangle (Csejtey and others, 1992).

AQUAGENE TUFF, ARGILLITE, LIMESTONE, CHERT, ANDESITE TUFF, AND GREENSTONE (late Paleozoic) (unit of Nokleberg and others, 1982) - Chiefly andesite flows, mud and debris avalanche deposits, and tuff interbedded with fine- to coarse-grained volcaniclastic rocks. Contains lesser interlayered basaltic aquagene tuff, gray-green andesite tuff, gray-green basalt, dark gray siliceous argillite, light gray to white calcite, limestone, and marble, and red and black chert. Thickness greater than $875 \mathrm{~m}$; base not exposed.

Aquagene tuff composed of fine- to medium-grained fragments of pillow rinds and basalt up to $7 \mathrm{~mm}$ across. Highly altered to very-fine-grained aggregates of chlorite, plagioclase, actinolite, graphite, and sericite. Local abundant fine-grained quartz fragments.

Light to dark gray andesite tuff composed of sparse to abundant plagioclase phenocrysts and crystal fragments, up to $2 \mathrm{~mm}$ long, in a very-fine-grained granoblastic matrix of actinolite, chlorite, and epidote. Local hornblende phenocrysts. Local felty groundmass composed of plagioclase microlites. Minor zircon and opaque minerals.

Basalt composed of fine-grained ophitic plagioclase and clinopyroxene partly recrystallized to granoblastic epidote, chlorite, actinolite, and sericite. Local clinopyroxene phenocrysts up to $2 \mathrm{~mm}$ long. Local relict ophitic to intergranular texture. Amygdaloidal. Sparse pillows exposed at base. Metamorphic minerals are epidote, chlorite, actinolite, sericite, calcite, and graphite. Generally thick bedded to massive.

Argillite composed of abundant, very-fine-grained clastic plagioclase in a matrix composed of either graphite, epidote, and chlorite or graphite, quartz, and clay. Locally tuffaceous. 
Light gray limestone and marble composed of granoblastic to schistose aggregates of medium-grained calcite and sparse dolomite containing local chert nodules, thin chert beds, and minor quartz grains.

Calcareous siltstone composed of approximately equal proportions of granoblastic to schistose calcite and quartz.

Gray to green-gray chert composed of granoblastic aggregates of very-fine-grained quartz and sparse sericite, chlorite, calcite, epidote, and opaque minerals and very sparse highly recrystallized radiolaria. Solitary corals occur in limy chert.

Unit generally granoblastic; local weak schistosity. Metamorphosed to lower greenschist facies. Diagnostic minerals are chlorite, epidote, actinolite, white mica, and graphite. Plagioclase partially replaced by white mica; clinopyroxene and hornblende replaced by chlorite and actinolite.

Unit well exposed in south-central Mount Hayes Quadrangle on east side of Maclaren River, in canyons in foothills north of East Fork of Eureka Creek, on north side of Amphitheater Mountains, and in narrow canyons cutting foothills to northwest of Wildhorse Creek. Underlies Nikolai Greenstone. Locally folded. Intruded by extensive dikes of gabbro and large sills of diabase and gabbro grading downward into cumulate mafic and ultramafic rocks. Basal unit of Tangle subterrane. Equivalent to middle and lower parts of Tangle Lakes Formation of Stout (1976). Sparse limestone lenses at one locality contain fragments of late Paleozoic bryozoans (table 1 of Nokleberg and others [1992a], locality 125). On strike to the west in Talkeetna Mountains D-2 Quadrangle; correlative unit contains limestones with Early through Late Permian conodonts (Kline and others, 1990).

\section{Metamorphic complex of Gulkana River south of Paxson Lake fault}

The metamorphic complex of Gulkana River (Nokleberg and others, 1986b) occurs in south-central Mount Hayes Quadrangle and northern Gulkana Quadrangle, south of Wrangellia terrane. Paxson Lake fault separates metamorphic complex to the south from Wrangellia terrane to the north. The metamorphic complex consists of: (1) Penetratively deformed and regionally metamorphosed Late Jurassic granitic and gabbroic plutonic rocks; (2) massive to intensely schistose, intensely metamorphosed upper Paleozoic(?) hornblende andesite and lesser clinopyroxene basalt; and (3) metamorphosed upper Paleozoic(?) pelitic and calc-schist, and quartz-feldspar schist.

The metamorphic complex has been correlated with lithologically similar Haley Creek metamorphic assemblage in northern Valdez Quadrangle to the southeast. Both have: (1) Similar upper Paleozoic metavolcanic and metasedimentary protoliths; (2) lithologically similar suites of older schistose gabbro and diorite plutons and younger schistose granitic plutons; (3) a similar Late Jurassic K-Ar age of metamorphism and deformation; and (4) a similar geologic history. The major differences between the metamorphic complex of Gulkana River and Haley Creek metamorphic assemblage are the more abundant metasedimentary rocks in Haley Creek metamorphic assemblage, and locally higher grade, synplutonic metamorphism for Haley Creek metamorphic assemblage (Nokleberg and others, 1989).

The metasedimentary and metavolcanic rocks of both Gulkana River metamorphic complex and Haley Creek metamorphic assemblage are derived from Early Pennsylvanian or older quartzofeldspathic, pelitic, and calcareous marine sedimentary rocks with subordinate mafic and intermediate volcanic rocks intruded by Pennsylvanian and Late Jurassic metaplutonic rocks (Nokleberg and others, 1989; Plafker and others, 1989). Together, Gulkana River metamorphic complex and Haley Creek metamorphic assemblage have been interpreted as the southern and deeper stratigraphic/structural levels of Wrangellia terrane (Plafker and others, 1989). Data supporting this interpretation are: (1) Occurrence of metamorphic complex along the southern margin of Wrangellia terrane for several hundred kilometers; and (2) occurrence of Pennsylvanian and younger rocks of Wrangellia terrane to the north and generally structurally, if not stratigraphically, above metamorphic complex.

Alternatively, metamorphic complex of Gulkana River may be a separate terrane juxtaposed between Wrangellia terrane to the north and Peninsular terrane to the south. The following data support this interpretation: (1) Metamorphic complex contains a penetrative fabric and a higher grade of metamorphism than Wrangellia terrane; (2) metamorphic complex contains a suite of syntectonic, two-mica granitic rocks that do not occur in Wrangellia terrane; and (3) the upper Paleozoic rocks of Wrangellia terrane do not stratigraphically overlie the metamorphic complex. Instead, Paxson Lake fault occurs between metamorphic complex and Wrangellia terrane. Additional studies are needed to resolve these differing interpretations.

\section{METAPLUTONIC ROCKS}

sqm SCHISTOSE QUARTZ MONZONITE (Late Jurassic)—Occurs as small plutons, stocks, and rare dikes throughout Gulkana River metamorphic complex. Consists of medium- to coarse-grained, two-mica quartz monzonite and 
lesser monzonite. Intrudes schistose granodiorite (sgd), schistose hornblende gabbro (shgb), and metamorphosed hornblende andesite (mha). Contains rare inclusions of quartz diorite. Weathers gray to dark gray. Schistose to locally mylonitic. Biotite and rare muscovite locally define a lineation. Generally anhedral to subhedral granular and porphyritic with rare interstitial K-feldspar. Minor myrmekitic and perthitic textures also occur. Rarely, hornblende and biotite occur in glomeroporphyritic clots. Primary minerals are hornblende, biotite, plagioclase, orthoclase, and quartz. Accessory minerals are opaques, zircon, apatite, and sphene. Chlorite, epidote, saussurite, and sericite are replacement minerals. Garnet and muscovite occur as minor metamorphic minerals. Phyric orthoclase encloses hornblende, biotite, plagioclase, and rare quartz. Plagioclase displays oscillatory zoning and complicated twinning. Composition averages $\mathrm{An}_{33}$. Minor biotite and hornblende are replaced by chlorite. Sparse plagioclase cores are altered to sericite, saussurite, and epidote. Rare quartz subgrains are present. Plagioclase and hornblende are locally fractured.

sqd SCHISTOSE QUARTZ DIORITE (Late Jurassic)—Occurs throughout northwestern Gulkana Quadrangle. Consists of fine- to medium-grained, two-mica quartz diorite and lesser hornblende quartz diorite, and tonalite. Intrudes metamorphosed hornblende andesite (mha), schistose hornblende gabbro (shgb), metamorphosed clinopyroxene basalt (mcb), and schistose granodiorite (sgd). Occurs as rare inclusions in schistose quartz monzonite (sqm). Finegrained disseminated sulfides are abundant. Weathers to dark gray. Textures are subhedral granular, porphyritic, and locally myrmekitic. They are schistose to locally mylonitic. Biotite and rare muscovite define a stretching lineation. Composition varies from $\mathrm{An}_{32}$ to $\mathrm{An}_{48}$. Major primary minerals are plagioclase, quartz, and biotite. Accessory minerals are orthoclase, sphene, brown hornblende, opaques, zircon, apatite, and relict clinopyroxene. Replacement minerals are saussurite, sericite, chlorite, epidote, and calcite. Rarely, garnet and muscovite occur as metamorphic minerals. Plagioclase is extensively replaced by sericite and saussurite. Biotite and hornblende are altered locally by chlorite. Relict clinopyroxene is replaced by hornblende.

sgd SCHISTOSE GRANODIORITE (Late Jurassic) - Occurs as plutons and stocks predominantly in Gulkana C-4 Quadrangle, and as minor occurrences throughout northwestern Gulkana Quadrangle. Composed of massive, medium- to coarse-grained, schistose, leucocratic, two-mica granodiorite with lesser granite. Includes minor pegmatite. Intrudes schistose hornblende gabbro (shgb) and metamorphosed hornblende andesite (mha). Contains rare inclusions of metamorphosed pelite (mmp). Chalcopyrite occurs sporadically in outcrop at Hogan Hill in Gulkana C-3 Quadrangle east of the Richardson Highway. A sulfide-bearing quartz vein occurs in a quarry in north Hogan Hill, and contains pyrite, chalcopyrite, bornite, sphalerite, and galena. Metamorphosed at upper greenschist to epidote-amphibolite facies. Biotite and muscovite define a northwest subhorizontal stretching lineation. Textures are anhedral to subhedral granular, porphyritic, graphitic and myrmekitic, and schistose to locally mylonitic. Primary minerals are quartz, plagioclase, and K-feldspar. Accessory minerals are sphene, apatite, opaques, and zircon. Replacement minerals are chlorite and saussurite. Muscovite, hornblende, garnet, epidote, and biotite are metamorphic minerals. Sparse K-feldspar phenocrysts up to $1.5 \mathrm{~cm}$ long. Minor quartz and K-feldspar are interstitial. Potassium feldspar occurs as microcline. Abundant chlorite replaces biotite and hornblende. Plagioclase is extensively altered by saussurite and sericite. Muscovite books up to $2 \mathrm{~cm}$ long. Quartz is commonly dynamically recrystallized. Biotite and hornblende are aligned and typically transverse schistosity, indicating recrystallization outlasted deformation.

shd SCHISTOSE HORNBLENDE DIORITE (Late Jurassic) — Occurs as small plugs and rare dikes in Gulkana D-3, D-4, and D-5 quadrangles. Underlies Round Top Mountain in Gulkana D-3 Quadrangle. Consists of medium- to coarse-grained hornblende diorite. Contains inclusions of metamorphosed hornblende andesite (mha). Textures are subhedral granular, porphyritic, and schistose to locally mylonitic. Primary minerals are plagioclase and hornblende. Accessory minerals are opaques and quartz. Replacement minerals are saussurite, epidote, zoisite, actinolite, chlorite, calcite, and sericite. Plagioclase phenocrysts locally up to $2 \mathrm{~cm}$ long. Composition generally varies from $\mathrm{An}_{32}$ to $\mathrm{An}_{41}$. Rare epidote porphyroblasts are also present. Hornblende is extensively altered to actinolite and chlorite. Plagioclase is replaced by saussurite, epidote, and minor sericite. Calcite typically occurs in veins. Some minor grains are fractured.

shgb SCHISTOSE HORNBLENDE GABBRO (Late Jurassic or older) — Occurs throughout northwestern Gulkana Quadrangle. Consists of massive, dark gray-green, fine- to medium-grained, schistose hornblende gabbro to lesser diabase plutons and stocks. Locally grades into minor hornblendite or chlorite-actinolite schist. Metamorphosed at greenschist facies. Intrudes metamorphosed hornblende andesite (mha) and schistose clinopyroxene gabbro (scgb). Fine-grained, chilled margins occur at contacts with metamorphosed hornblende andesite (mha). Intruded by schistose hornblende diorite (shd), schistose granodiorite (sgd), and schistose quartz diorite (sqd). Contains inclusions of metamorphosed hornblende andesite (mha). Rarely mylonitic. Relict igneous textures are subhedral 
granular, subophitic, and porphyritic. Sparse plagioclase occurs in glomeroporphyritic clusters. Primary minerals are hornblende and plagioclase. Accessory primary minerals are clinopyroxene, sphene, quartz, biotite, zircon, and opaques. Metamorphic minerals are chlorite, actinolite, muscovite, zoisite, clinozoisite, rare garnet, prehnite, and epidote. Retrogressive minerals are sericite, saussurite, calcite, and tremolite. Plagioclase composition generally ranges from $\mathrm{An}_{55}$ to $\mathrm{An}_{60}$. Plagioclase is extensively altered to saussurite, sericite, and rare epidote. Hornblende is replaced by chlorite, actinolite, and rare tremolite. Clinopyroxene is replaced by chlorite, sparse epidote, and hornblende. Minor biotite is altered to chlorite. Hornblende and clinopyroxene are rarely fractured. Epidote typically occurs in veins.

$\mathrm{scgb}$ SCHISTOSE CLINOPYROXENE GABBRO (Late Jurassic or older) - Occurs as small plutons and stocks throughout northwestern Gulkana Quadrangle. Consists of green to dark green, medium- to coarse-grained clinopyroxene gabbro and sparse diabase that are rarely pegmatitic. Metamorphosed at greenschist facies. Grades locally into chlorite schist. Intrudes metamorphosed hornblende andesite (mha). Contains minor disseminated pyrite. Relict igneous textures are subhedral granular and subophitic. Rare myrmekitic texture also occurs. Primary minerals are clinopyroxene and plagioclase. Minor primary minerals are opaques, quartz, zircon, and hornblende. Metamorphic minerals are muscovite, chlorite, actinolite, and epidote. Retrogressive minerals are saussurite and sericite. Hornblende and clinopyroxene phenocrysts are up to $4.5 \mathrm{~cm}$ long. Composition varies from $\mathrm{An}_{45}$ to $\mathrm{An}_{62}$. Plagioclase is replaced by saussurite and sericite. Clinopyroxene is altered to sparse chlorite. Rare hornblende is altered to chlorite and minor actinolite. Minor fracturing occurs.

AMPHIBOLITE GNEISS (Late Jurassic or older) — Occurs in northern Gulkana C-3, D-3, and D-4 quadrangles. Consists of fine-grained biotite granodiorite, hornblende quartz diorite, and rare tonalite metamorphosed at epidoteamphibolite to amphibolite facies. Contains biotite-rich schist inclusions from a few centimeters to $1 \mathrm{~m}$ long that display boudinage and pinch and swell. Contains a steeply dipping foliation and northwest-trending, subhorizontal lineation. Typically granoblastic and schistose to mylonitic. Relict myrmekitic texture occurs locally. Preserved primary minerals are plagioclase, quartz, brown hornblende, and biotite. Accessory minerals are orthoclase, sphene, apatite, zircon, and opaques. Metamorphic minerals are garnet, green hornblende, calcic plagioclase, epidote, and minor biotite. Retrogressive minerals are saussurite and sericite. Rare augen of plagioclase indicate dextral motion. Poikiloblastic hornblende and biotite commonly are transverse to schistosity, indicating recrystallization outlasted deformation. Poikiloblastic garnet is pre- to synkinematic. Dynamically recrystallized quartz occurs locally. Relict igneous plagioclase displays complicated twinning and normal zoning. Composition of relict igneous plagioclase ranges from $\mathrm{An}_{33}$ to $\mathrm{An}_{39}$. Calcic plagioclase yields compositions that average $\mathrm{An}_{49}$. Plagioclase is altered to saussurite and minor sericite. Contains quartz veins 0.5 to $3 \mathrm{~cm}$ thick.

\section{Isotopic ages of metaplutonic rocks}

Most of the new K-Ar isotopic ages for amphibole, biotite, hornblende, and muscovite from metaigneous rocks (units sqm, sgd, mhd, sqd, shgb) in northern Gulkana Quadrangle range from 131 to $146 \mathrm{Ma}$. And a U-Pb zircon isotopic age is $166 \pm 76 \mathrm{Ma}$. These ages are interpreted as the time of late Middle Jurassic to early Early Cretaceous syntectonic intrusion of the plutonic and coeval syntectonic metamorphism of the wall rocks (units mha, qmfs, $\mathrm{mmp}, \mathrm{mcb}, \mathrm{am}$ ) adjacent to the plutons. These ages and style of metamorphism in both plutonic and wall rock is similar to Haley Creek metamorphic assemblage in northern Valdez Quadrangle to the southeast.

Two K-Ar hornblende isotopic ages and one K-Ar amphibole isotopic age are much older, with values of 233, 282, and 1,356 Ma (table 1 of Nokleberg and others [1992a]). The geologic cause of of the older ages is unknown.

\section{METAMORPHOSED VOLCANIC AND SEDIMENTARY ROCKS}

mha METAMORPHOSED HORNBLENDE ANDESITE (upper Paleozoic[?] or older) - Occurs throughout northwestern Gulkana Quadrangle. Consists of massive, fine- to medium-grained, dark green to dark gray-green, metamorphosed hornblende andesite, and lesser andesite tuff and pillow andesite. Locally interlayered with sparse, thin- to medium-bedded quartz siltstone, calcareous shale, chert, and marble. Also contains thin, discontinuous layers of black phyllite. Intruded by schistose hornblende (shgb), clinopyroxene gabbro (scgb), schistose hornblende diorite (shd), and schistose quartz diorite (sqd). Occurs as sparse lenses in schistose hornblende gabbro (shgb). Metamorphosed at greenschist facies. Grades locally into chlorite schist. Contains minor disseminated pyrite. Deformed amygdules are filled with quartz, calcite, chlorite, and epidote. Rare microlites of plagioclase define felty texture. Other textures are porphyritic and schistose to rarely mylonitic. Sparse plagioclase occurs in glomeroporphyritic clusters. Locally, crenulation cleavage is present. Minor isoclinal folds occur with near-vertical fold axes and parallel mineral stretching lineations. Major primary minerals are plagioclase and hornblende. Accessory minerals are quartz, clinopyroxene, biotite, opaques, and zircon. Metamorphic minerals are actinolite, chlorite, epidote, 
and zoisite. Replacement minerals are saussurite, calcite, and sericite. Composition of plagioclase averages $\mathrm{An}_{30}$. Hornblende is replaced by actinolite and chlorite. Plagioclase is extensively altered to saussurite and sericite. Sparse clinopyroxene is altered to chlorite. Quartz subgrains occur locally; minor grains are fractured. Chlorite, actinolite, and hornblende are stretched and define a schistosity.

Unit occurs in several outcrops along southern Mount Hayes A-4 and A-5 quadrangles and northeastern Gulkana Quadrangle. Faulted against Tangle subterrane along concealed Paxson Lake fault. Includes pre-Pennsylvanian(?) greenschists and amphibolites of Stout (1976). Faulted along northern margin. Estimated structural thickness of a few hundred meters.

qmfs QUARTZ-MUSCOVITE-FELDSPAR SCHIST (upper Paleozoic[?] or older) — Occurs in southern Gulkana D-6 and northern Gulkana C-6 quadrangles. Consists of massive, schistose to mylonitic quartz-muscovite-feldspar schist derived from leuco-andesite. Metamorphosed at greenschist facies. Relict primary minerals are plagioclase, opaques, and quartz. Metamorphic minerals are muscovite, epidote, chlorite, actinolite, and zoisite. Retrogressive

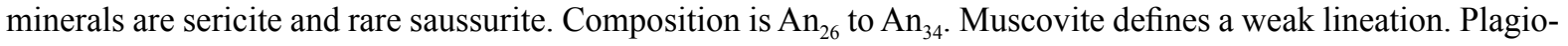
clase is replaced by sericite and sparse saussurite.

mmp METAMORPHOSED PELITIC AND CALC-SCHIST (upper Paleozoic[?] or older) — Occurs locally throughout Gulkana Quadrangle. Consists of gray to light gray, pelitic schist, calc-schist, and white marble derived from shale, quartz, calcareous siltstone, and limestone. Sparsely interbedded with metamorphosed hornblende andesite (mha) flows. Intruded by schistose hornblende gabbro (shgb) and schistose granodiorite (sgd). Occurs as rare inclusions in schistose granodiorite (sgd). Metamorphosed at lower to upper greenschist facies. Medium to thick bedded with sparse pyrite and local iron-stained bands. Texture is schistose to mylonitic. Biotite, minor muscovite, and actinolite define a lineation. Quartz subgrains occur in elongate voids parallel to schistosity. Metamorphic minerals include cordierite, andalusite, biotite, and muscovite. Relict minerals are quartz, plagioclase, calcite, and opaques. Retrogressive minerals are chlorite, sericite, and actinolite. Calc-schist derived from marl. The metamorphic assemblage in pelitic schist is cordierite-biotite-muscovite + andalusite. The metamorphic assemblage in metamorphosed siltstones is quartz-biotite-albite + muscovite. Composition on relict igneous plagioclases ranges from $\mathrm{An}_{35}$ to $\mathrm{An}_{40}$. Plagioclase is microboudinaged in a few places. Cordierite and andalusite are synkinematic, and are stretched in the plane of schistosity. Cordierite displays penetration twins, and is locally replaced by sericite. Muscovite is locally poikiloblastic. Minor biotite is altered to chlorite. Plagioclase is extensively replaced by muscovite. Metamorphosed hornblende andesite layers grade locally into chlorite schist with rare isoclinal folds. Relict graded bedding occurs in a few metasiltstone layers. Minor calcite is recrystallized. Some grains are fractured locally.

mcb METAMORPHOSED CLINOPYROXENE BASALT (upper Paleozoic[?] or older) — Occurs in northern Gulkana D-4 Quadrangle. Consists of massive, green to dark green, fine-grained, metamorphosed clinopyroxene basalt. Locally intruded by schistose quartz diorite (sqd) stocks near Flat Top Mountain. Metamorphosed to lower greenschist facies. Contains minor flattened amygdules filled with quartz, calcite, and chlorite. Textures include aphanitic, subophitic, porphyritic, schistose, and glomeroporphyritic. Primary minerals are clinopyroxene and plagioclase. Accessory minerals are hornblende and opaques. Metamorphic minerals are actinolite and chlorite. Retrogressive minerals are sericite and saussurite. Composition ranges from $\mathrm{An}_{38}$ to $\mathrm{An}_{60}$. Plagioclase is altered to sericite and saussurite. Minor clinopyroxene is altered to chlorite. Hornblende is rarely replaced by chlorite and actinolite.

am AMPHIBOLITE (upper Paleozoic[?] or older)—Underlies Hogan Hill along the Richardson Highway in northeastern Gulkana C-3 Quadrangle. Unit is well exposed in quarries at southern and northern parts of Hogan Hill. Consists of green to green-black hornblende amphibolite derived from fine-grained hornblende andesite or basalt. Locally interlayered with metamorphosed tuffaceous argillite, rare siltstone, and shale that are black to gray-black, 2-20 $\mathrm{cm}$ thick, and locally boudinaged. Metamorphosed at epidote-amphibolite and amphibolite facies. Disseminated sulfides occur locally. Major metamorphic minerals are hornblende, calcic plagioclase, and epidote. Accessory minerals include opaques and quartz. Minor retrogressive minerals are actinolite, chlorite, zoisite, and sericite. Stretched, poikiloblastic hornblende defines a well-developed schistosity that is parallel to relict graded bedding. Relict bedding indicates tops to the northeast. A crenulating cleavage and minor pinch and swells also occur. Schistosity and bedding generally strike $\mathrm{N} 35^{\circ} \mathrm{W}$ and dip $75^{\circ} \mathrm{NE}$. A subhorizontal lineation trends $\mathrm{N} 35^{\circ} \mathrm{W}$ and plunges $12^{\circ}$. A second subtle lineation trends at $\mathrm{N} 55^{\circ} \mathrm{E}$ and plunges $60^{\circ}$, suggesting dip-slip movement. Plagioclase phenocrysts are flattened in the plane of schistosity. Anastomosing zones of fault gauge and boudinaged quartz veins are common. Rare veins of quartz and epidote are transverse to schistosity. Amygdules are flattened parallel to schistosity and are filled with quartz, epidote, and chlorite. Plagioclase is locally replaced by sericite. Rare hornblende is altered to actinolite and chlorite. Sparse hornblende and plagioclase are fractured. 


\section{Peninsular terrane}

The Peninsular terrane, originally defined by Jones and others (1977) occurs in west-central and southwestern Gulkana Quadrangle, south of Gulkana River metamorphic complex. West Fork fault occurs between the two units (fig. 1). In Gulkana Quadrangle, Peninsular terrane consists of (1) Lower Jurassic marine andesite flows and related rocks (Talkeetna Formation); and (2) Cretaceous fine-grained sedimentary rocks (Matanuska Formation). Peninsular terrane is also intruded by sparse Early Cretaceous granodiorite (fig. 1) that may be part of the Early Cretaceous Chisna arc.

The major tectonic event characterizing Peninsular terrane is the early Mesozoic Talkeetna arc represented in Gulkana Quadrangle by Lower Jurassic Talkeetna Formation, and the Middle Jurassic part of Alaska-Aleutian Range batholith that occurs to the southwest of the quadrangle. The Talkeetna arc is a major Mesozoic feature in the study area that extends for more than 1,500 km along the length of Alaska Peninsula and northeastward to eastern Copper River basin. The arc was originally defined by Plafker and others (1989) as an Early Jurassic feature composed of deep-level ultramafic and mafic rocks of the Border Ranges ultramafic-mafic assemblage, exposed in northern Valdez Quadrangle to the south. This assemblage is interpreted as the roots to the volcanic and related rocks of Talkeetna Formation (Plafker and others, 1989).

Geochemical data indicate an island arc origin for the Talkeetna arc. Andesite and basalt from Talkeetna Formation in Talkeetna Mountains show affinities with a medium-K, tholeiitic type of orogenic andesite; these data are compatible with an island arc origin (Barker and Grantz, 1982; Barker, 1994). Compatible geochemical data were also obtained at easternmost outcrops of Talkeetna Formation along the Richardson Highway (Plafker and others, 1989). The Middle Jurassic plutonic rocks exhibit relatively low initial Sr ratios (Reed and Lanphere, 1972; Reed and others, 1983; Barker, 1994; Miller, 1994).

The polarity of the arc is interpreted as southeast based on occurrence of northward-dipping, coeval subduction zone assemblages in northern Chugach terrane that occur across the Border Ranges fault to the south in Valdez Quadrangle (Plafker and others, 1989, 1994). Units constituting these subduction zone assemblages are mainly (1) Discontinuous outcrops of blueschist and locally interlayered greenschist exposed along northern margin of Chugach terrane from Kodiak Island to eastern Chugach Mountains, with metamorphic ages that range mainly from $204 \mathrm{Ma}$ to $154 \mathrm{Ma}$ (see summaries in Plafker and others, 1989, 1994); and (2) older parts of subduction zone mélange of McHugh Complex, which contain Late Triassic through mid Cretaceous radiolarian chert (Winkler and others, 1981; Plafker and others, 1989, 1994) that may have been accreted during the existence of the Talkeetna arc. These relations indicate that latest Triassic through Middle(?) Jurassic Talkeetna arc to the north and Upper Triassic through Middle Jurassic parts of accretionary assemblages to the south are remnants of a paired igneous arc and subduction zone complex, now juxtaposed along the Border Ranges fault (Plafker and others, 1989, 1994).

\section{PLUTONIC ROCKS}

hbqd HORNBLENDE-BIOTITE QUARTZ DIORITE (Cretaceous or Jurassic) — Occurs in southern Gulkana C-6 Quadrangle. Consists of massive, fine- to medium-grained hornblende-biotite quartz diorite. Intrudes hornblende-biotite granodiorite (hbgd). Locally metamorphosed at lower greenschist facies. Textures are porphyritic and anhedral to subhedral granular. Primary minerals are biotite, hornblende, quartz, K-feldspar, and plagioclase. Accessory minerals are opaques and zircon. Replacement minerals are sericite, epidote, saussurite, and chlorite. Plagioclase displays oscillatory zoning. Composition ranges from $\mathrm{An}_{39}$ to $\mathrm{An}_{48}$. Plagioclase is altered to saussurite, sericite, and rare epidote. Minor hornblende and biotite are replaced by chlorite.

hbqm HORNBLENDE-BIOTITE QUARTZ MONZONITE (Cretaceous or Jurassic) — Occurs in western Gulkana C-5 Quadrangle. Consists of light gray to white-gray, medium-grained, hornblende-biotite quartz monzonite to granite with lesser granodiorite. Textures are subhedral granular, porphyritic, and locally glomeroporphyritic. Locally metamorphosed to lower greenschist facies. Major primary minerals are plagioclase, quartz, and K-feldspar. Minor accessory minerals are hornblende, biotite, clinopyroxene, apatite, zircon, and opaques. Replacement minerals are chlorite, epidote, sericite, and saussurite. Plagioclase displays oscillatory and normal zoning. Composition ranges from $\mathrm{An}_{30}$ to $\mathrm{An}_{38}$. Quartz and orthoclase are interstitial. Hornblende and rare clinopyroxene occur in glomeroporphyritic clusters. Plagioclase is altered to saussurite, sericite, and sparse epidote. Hornblende, biotite, and rare clinopyroxene are rarely replaced by chlorite.

hbgd HORNBLENDE-BIOTITE GRANODIORITE (Cretaceous or Jurassic) - Occurs in Gulkana C-5 Quadrangle and consists of massive, fine- to medium-grained, hornblende-biotite granodiorite. Contains sparse inclusions of andesite. Locally metamorphosed at lower greenschist facies. Textures are porphyritic and subhedral granular. Primary minerals are plagioclase, quartz, biotite, hornblende, and K-feldspar. Accessory minerals are opaques, 
apatite, and rare zircon. Replacement minerals are chlorite, saussurite, and sericite. Plagioclase is normally zoned with complicated twinning. Composition averages $\mathrm{An}_{35}$. Plagioclase is altered to saussurite, sericite, and minor epidote. Hornblende and biotite are replaced by chlorite.

\section{TALKEETNA FORMATION (LOWER JURASSIC)}

Various units of Talkeetna Formation crop out in Gulkana C-5 and C-6 quadrangles and contine to the west in Talkeetna Mountains Quadrangle (Csejtey and others, 1978) and farther to the west-southwest onto Alaska Peninsula (Nokleberg and others, 1994). In Gulkana Quadrangle, unit consists of rhyodacite and dacite flows, hornblende andesite flows, sandstone, and volcaniclastic rocks.

Jtrd RHYODACITE AND DACITE FLOWS - Occurs in southern Gulkana C-6 Quadrangle. Consists of medium layered, fine-grained rhyodacite flows; interbedded with lesser dacite flows and minor sandstone. Weathers to buff-light gray to green-gray, and forms resistant ledges. Contains 10-cm-long clasts of greenstone and conglomeratic sandstone. Contains clasts of andesite porphyry in a coarse, sand-sized matrix of greenstone, quartz, and K-feldspar. Fragments vary from angular to rounded and exhibit subtle alignment. Silicified and tuffaceous with sporadic lithics. Locally metamorphosed to lower greenschist facies. Primary minerals are plagioclase and K-feldspar. Quartz is minor accessory mineral. Replacement minerals are actinolite, saussurite, calcite, epidote, chlorite, and zoisite. Glass occurs locally. Plagioclase altered to saussurite and rare epidote. Hornblende altered to chlorite and actinolite.

Jta HORNBLENDE ANDESITE FLOWS-Occur in southern Gulkana C-5 and C-6 quadrangles, and consists of massive, dark green, fine-grained, porphyritic hornblende andesite flows that are medium to thick layered. Weathers to red-brown with local iron stains. Plagioclase phenocrysts up to $2 \mathrm{~cm}$ long. Primary minerals are plagioclase and hornblende. Locally metamorphosed to greenschist facies. Accessory minerals include quartz and opaques. Replacement minerals are chlorite, actinolite, epidote, and prehnite. Plagioclase is altered to saussurite. Hornblende is altered to chlorite and minor actinolite.

Jts SANDSTONE AND VOLCANICLASTIC ROCKS-Rare occurrence in southern Gulkana C-6 Quadrangle. Consists of medium-layered, fine-grained sandstone with sparse volcaniclastic rocks. Quartz is the major mineral. Accessory minerals are K-feldspar, calcite, plagioclase, muscovite, actinolite, saussurite, and opaques. Relict plagioclase composition ranges from $\mathrm{An}_{38}$ to $\mathrm{An}_{45}$. Quartz grains are commonly angular. 


\section{REFERENCES CITED}

Aleinikoff, J.N., 1984, Age and origin of metaigneous rocks from terranes north and south of the Denali fault, Mount Hayes Quadrangle, east-central Alaska [abs.]: Geological Society of America Abstracts with Programs, v. 16, no. 5, p. 266.

1985, Age of intrusion and metamorphism of a granodiorite in the Lake George terrane, northeastern Mount Hayes Quadrangle, Alaska, in Bartsch-Winkler, Susan, and Reed, K.M., eds., The United States Geological Survey in Alaska-Accomplishments during 1983: U.S. Geological Survey Circular 945, p. 62-65.

Aleinikoff, J.N., and Nokleberg, W.J., 1983, Uranium-lead geochronology of a metarhyodacite from the Pingston terrane, Mount Hayes C-6 Quadrangle, eastern Alaska Range, Alaska, in Coonrad, W.L., and Elliott, R.L., eds., The United States Geological Survey in Alaska-Accomplishments during 1981: U.S. Geological Survey Circular 868, p. 73-75.

1984, Early Proterozoic metavolcanic rocks in the Jarvis Creek Glacier tectonostratigraphic terrane, Mount Hayes C-6 Quadrangle, eastern Alaska Range, Alaska, in Reed, K.M., and Bartsch-Winkler, S.R., eds., The United States Geological Survey in Alaska-Accomplishments during 1982: U.S. Geological Survey Circular 939, p. 40-44.

1985, Age of Devonian igneous-arc terranes in the northern Mount Hayes Quadrangle, eastern Alaska Range, Alaska, in Bartsch-Winkler, Susan, ed., The United States Geological Survey in Alaska-Accomplishments during 1984: U.S. Geological Survey Circular 967, p. 44-49.

Aleinikoff, J.N., Dusel-Bacon, C., and Foster, H.L., 1986, Geochronology of augen gneiss and related rocks, YukonTanana terrane, east-central Alaska: Geological Society of America Bulletin, v. 97, p. 626-637.

Aleinikoff, J.N., Dusel-Bacon, C., Foster, H.L., and Nokleberg, W.J., 1987, Pb-isotope fingerprinting of tectonostratigraphic terranes, east-central Alaska: Canadian Journal of Earth Sciences, v. 24, p. 2,089-2,098.

Aleinikoff, J.N., Foster, H.L., Nokleberg, W.J., and DuselBacon, Cynthia, 1984, Isotopic evidence from detrital zircons for early Proterozoic crustal material, east-central Alaska, in Coonrad, W.L., and Elliott, R.L., eds., The United States Geological Survey in Alaska-Accomplishments during 1981: U.S. Geological Survey Circular 868 , p. 43-45.

Aleinikoff, J.N., Nokleberg, W.J., and Herzon, P.L., 1981, Age of intrusion and metamorphism of the East Susitna batholith, Mount Hayes B-6 Quadrangle, eastern Alaska Range, Alaska, in Coonrad, W.L., ed., The United States Geological Survey in Alaska-Accomplishments during 1980: U.S. Geological Survey Circular 844, p. 100-200.

Barker, Fred, and Grantz, Arthur, 1982, Talkeetna Formation in the southeastern Talkeetna Mountains, southern Alaska-An Early Jurassic andesitic island arc:
Geological Society of America Abstracts with Programs, v. 14, p 147.

Barker, Fred, 1994, Some accreted volcanic rocks of Alaska and their elemental abundances, in Plafker, George, and Berg, H.C., eds., The Geology of Alaska: Boulder, Colorado, Geological Society of America, The Geology of North America, v. G-1, p. 555-588.

Barker, Fred, and Stern, T.W., 1986, An arc-root complex of Wrangellia, eastern Alaska Range [abs.]: Geological Society of America Abstracts with Programs, v. 18, p. 534.

Barker, Fred, Sutherland Brown, A., Budahn, J.R., and Plafker, George, 1989, Back-arc with frontal arc component origin of Triassic Karmutsen basalt, British Columbia, Canada: Chemical Geology, v. 75, p. 81-102.

Beard, J.S., and Barker, Fred, 1989, Petrology and tectonic significance of gabbros, tonalites, shoshonites, and anorthosites in a late Paleozoic arc-root complex in the Wrangellia terrane, southern Alaska: Journal of Geology, v. 97, p. 667-683.

Berg, H.C., Jones, D.L., and Richter, D.H., 1972, GravinaNutzotin belt-Tectonic significance of an upper Mesozoic sedimentary and volcanic sequence in southern and southeastern Alaska, in Geological Survey Research 1972: U.S. Geological Survey Professional Paper 800-D, p. D1-D24.

Bond, G.C., 1973, A late Paleozoic volcanic arc in the eastern Alaska Range, Alaska: Journal of Geology, v. 81, p. $557-575$.

1976, Geology of the Rainbow Mountain-Gulkana Glacier area, eastern Alaska Range, with emphasis on upper Paleozoic strata: Alaska Division of Geological \& Geophysical Surveys Geologic Report 45, 47 p., 3 sheets, scale 1 inch $=400$ feet. doi:10.14509/373

Csejtey, Béla, Jr., Nelson, W.H., Jones, D.L., Silberling, N.J., Dean, R.M., Morris, M.S., Lanphere, M.A., Smith, J.G., and Silberman, M.L., 1978, Reconnaissance geologic map and geochronology, Talkeetna Mountains Quadrangle, northern part of Anchorage Quadrangle, and southwest corner of Healy Quadrangle, Alaska: U.S. Geological Survey Open-File Report 78-558-A, 62 p., 1 plate, scale 1:250,000.

Csejtey, Béla, Jr., Mullen, M.W., Cox, D.P., and Stricker, G.D., 1992, Geology and geochronology of the Healy Quadrangle, south-central Alaska: U.S. Geological Survey, Miscellaneous Investigation Series I-1961, 63 p., scale $1: 250,000$.

Dashevsky, S.S., Schaefer, C.F., and Hunter, E.N., 2003, Bedrock geologic map of the Delta mineral belt, Tok mining district, Alaska: Alaska Division of Geological \& Geophysical Surveys Professional Report 122, 122 p., 2 sheets, scale 1:63,360. doi:10.14509/2923

Davidson, Cameron, Hollister, L.S., and Schmid, S.M., 1992, Role of melt in the formation of a deep-crustal compressive shear zone-The Maclaren Glacier metamorphic belt, south-central Alaska: Tectonics, v. 11, no. 2, p. 348-359. 
Dusel-Bacon, Cynthia, and Aleinikoff, J.N., 1985, Petrology and tectonic significance of augen gneiss from a belt of Mississippian granitoids in the Yukon-Tanana terrane, east-central Alaska: Geological Society of America Bulletin, v. 96, no. 4, p. 411-425.

Dusel-Bacon, Cynthia, Hopkins, M.J., Mortensen, J.K., Dashevsky, S.S., Bressler, J.R., and Day, W.C., 2006, Paleozoic tectonic and metallogenic evolution of the pericratonic rocks of east-central Alaska and adjacent Yukon Territory, in Colpron, Maurice, and Nelson, J.L., eds., Paleozoic evolution and metallogeny of pericratonic terranes at the ancient Pacific margin of North America, Canadian and Alaskan Cordillera: Geological Association of Canada Special Paper 45, p. 25-74.

Ferrians, O.J., Jr., 1971, Preliminary engineering geologic maps of the proposed trans-Alaska pipeline route, Gulkana Quadrangle: U.S. Geological Survey Open-File Report 71-102 (494), scale 1:125,000, 2 sheets.

Foley, J.Y., 1982, Alkaline igneous rocks in the eastern Alaska Range, in Alaska Division of Geological \& Geophysical Surveys, Short Notes on Alaskan Geology_1981: Alaska Division of Geological \& Geophysical Surveys Geologic Report 73A, p. 1-5. doi:10.14509/434

1984, Petrology, geochemistry, and geochronology of alkaline dikes and associated plutons in the eastern Mount Hayes and western Tanacross quadrangles, Alaska: Fairbanks, Alaska, University of Alaska, M.S. thesis, 95 p., 1 sheet, scale 1:63,360.

Foster, H.L., 1970, Reconnaissance geologic map of the Tanacross Quadrangle, Alaska: U.S. Geological Survey Miscellaneous Geologic Investigations Map I-593, 1 sheet, scale 1:250,000.

Foster, H.L., Keith, T.E.C., and Menzie, W.D., 1987, Geology of east-central Alaska: U.S. Geological Survey Open-File Report 87-188, 59 p.

Fuis, G.S., Moore, T.E., Plafker, George, Brocher, T.M., Fisher, M.A., Mooney, W.D., Nokleberg, W.J., Page, R.A., Beaudoin, B.C., and Christensen, N.I., 2008, TransAlaska Crustal Transect and continental evolution involving subduction underplating and synchronous foreland thrusting: Geology, v. 36, p. 267-270.

Grantz, Arthur, 1953, Preliminary report on the geology of the Nelchina area, Alaska: U.S. Geological Survey Open-File Report 53-79, 2 p., maps and sections.

Holmes, G.W., 1965, Geologic reconnaissance along the Alaska Highway, Delta River to Tok Junction, Alaska: U.S. Geological Survey Bulletin 1181-H, p. H1-H19.

Holmes, G.W., and Benninghoff, W.S., 1957, Terrain study of the Army Test Area, Fort Greely, Alaska: U.S. Geological Survey, Military Geologic Branch, v. 1, 287 p.; v. 2, maps.

Holmes, G.W., and Foster, H.L., 1968, Geology of the Johnson River area, Alaska: U.S. Geological Survey Bulletin $1249,49 \mathrm{p}$.

Holmes, G.W., and Péwé, T.L., 1965, Geologic map of the Mount Hayes D-3 Quadrangle, Alaska: U.S. Geological Survey Geological Quadrangle Map GQ-366, scale $1: 63,360$.
Jones, D.L., Silberling, N.J., Coney, P.J., and Plafker, George, 1987, Lithotectonic terrane map of Alaska: U.S. Geological Survey Map MF-1874-A, 1 sheet, scale 1:2,500,000.

Jones, D.L., Silberling, N.J., Gilbert, W.G., and Coney, P.J., 1982, Character, distribution, and tectonic significance of accretionary terranes in the central Alaska Range: Journal of Geophysical Research, v. 87, no. B5, P. 3,709-3,717.

Jones, D.L., Silberling, N.J., and Hillhouse, J., 1977, Wrangellia-A displaced terrane in northwestern North America: Canadian Journal of Earth Sciences, v. 14, no. 11, p. 2,565-2,577.

Kline, J.T., Bundtzen, T.K., and Smith, T.E., 1990, Preliminary bedrock geologic map of the Talkeetna Mountains D-2 Quadrangle, Alaska: Alaska Division of Geological \& Geophysical Surveys Public Data File 90-24, 13 p., 1 sheet, scale 1:63,360. doi:10.14509/1458

LeHurray, A.P., Church, S.E., and Nokleberg, W.J., 1985, Lead isotopes in sulfide deposits from the Jarvis Creek Glacier and Wrangellia terranes, Mount Hayes Quadrangle, eastern Alaska Range, in Bartsch-Winkler, Susan, and Reed, K. M., eds., The United States Geological Survey in Alaska-Accomplishments during 1983: U.S. Geological Survey Circular 945, p. 72-73.

MacKevett, E.M., Jr., 1978, Geologic map of the McCarthy Quadrangle, Alaska: U.S. Geological Survey Miscellaneous Investigations Series Map I-1032, 1 sheet, scale $1: 250,000$.

MacKevett, E.M., Jr., and Richter, D.H., 1974, The Nikolai Greenstone in the Wrangell Mountains, Alaska, and nearby regions [abs.]: Geological Association of Canada, Cordillera Section, Program and Abstracts, Vancouver, p. 13-14.

Mendenhall, W.C., 1900, A reconnaissance from Resurrection Bay to the Tanana River, Alaska, in 1898: U.S. Geological Survey 20th Annual Report, part 7, p. 265-340.

1905, Geology of the central Copper River region, Alaska: U.S. Geological Survey Professional Paper 41, $133 \mathrm{p}$.

Mendenhall, W.C., and Schrader, F.C., 1903, The mineral resources of the Mount Wrangell district, Alaska: U.S. Geological Survey Professional Paper 15, 71 p.

Miller, T.P., 1994, Pre-Cenozoic plutonic rocks in mainland Alaska, in Plafker, George, and Berg, H.C., eds., The Geology of Alaska: Boulder, Colorado, Geological Society of America, The Geology of North America, v. G-1, p. 535-554.

Moffit, F.H., 1912, Headwaters regions of Gulkana and Susitna Rivers, Alaska, with accounts of the Valdez Creek and Chistochina placer districts: U.S. Geological Survey Bulletin 498, 82 p.

1932, The Slana district, upper Copper River region: U.S. Geological Survey Bulletin 824, p. 111-124.

1936, Upper Copper and Tanana Rivers: U.S. Geological Survey Bulletin 868-C, p. 135-143.

1937, Recent mineral developments in the Copper River region: U.S. Geological Survey Bulletin 880-B, p. 97-109. 
Moffit, F.H., 1938a, Geology of the Chitina Valley and adjacent area, Alaska: U.S. Geological Survey Bulletin 894, 137 p.

1938b, Geology of the Slana-Tok district, Alaska:

U.S. Geological Survey Bulletin 904, 54 p.

1942, Geology of the Gerstle River district, Alaska, with a report on the Black Rapids Glacier: U.S. Geological Survey Bulletin 926, p. 107-160.

1944, Mining in the northern Copper River region, Alaska: U.S. Geological Survey Bulletin 943-B, p. 25-47.

1954, Geology of the eastern part of the Alaska Range and adjacent area: U.S. Geological Survey Bulletin 989D, p. 63-218, 1 sheet, scale 1:250,000.

Monger, J.W.H., and Berg, H.C., 1987, Lithotectonic terrane map of western Canada and southeastern Alaska: U.S. Geological Survey Map MF-1874-B, 1 sheet, scale $1: 2,500,000,12 \mathrm{p}$.

Nokleberg, W.J., and Aleinikoff, J.N., 1985, Summary of stratigraphy, structure, and metamorphism of Devonian igneous-arc terranes, northeastern Mount Hayes Quadrangle, eastern Alaska Range, in Bartsch-Winkler, Susan, ed., The United States Geological Survey in Alaska-Accomplishments during 1984: U.S. Geological Survey Circular 967, p. 66-71.

Nokleberg, W.J., Aleinikoff, J.H., Bundtzen, T.K., and Hanshaw, M.N., 2013, Geologic strip map along the Hines Creek Fault showing evidence for Cenozoic displacement in the western Mount Hayes and northeastern Healy quadrangles, eastern Alaska Range, Alaska: U.S. Geological Survey Scientific Investigations Map 3238, pamphlet 31 p., scale 1:63,360,

Nokleberg, W.J., and Richter, D.H., 2007, Origin of narrow terranes and adjacent major terranes occurring along the Denali fault in the eastern and central Alaska Range, Alaska, in Ridgway, K.D., Trop, J.M., Glen, J.M.G., and ONeill, J.M., eds., Tectonic Growth of a Collisional Continental Margin: Crustal Evolution of Southern Alaska: Geological Society of America Special Paper 431, p. 129-154.

Nokleberg, W.J., Albert, N.R.D., Bond, G.C., Herzon, P.L., Miyaoka, R.T., Nelson, W.H., Richter, D.H., Smith, T.E., Stout, J.H., Yeend, Warren, and Zehner, R.E., 1982, Geologic map of the southern part of the Mount Hayes Quadrangle, Alaska: U.S. Geological Survey Open-File Report 82-52, 26 p., scale 1:250,000.

Nokleberg, W.J., Albert, N.R.D., Herzon, P.L., Miyaoka, R.T., and Zehner, R.E., 1981a, Cross section showing accreted Andean-type arc and island arc terranes in southwestern Mount Hayes Quadrangle, Alaska, in Albert, N.R.D., and Hudson, Travis, eds., The United States Geological Survey in Alaska-Accomplishments during 1979: U.S. Geological Survey Circular 823-B, p. B66-B67.

1981b, Recognition of two subterranes within the Wrangellia terrane, southern Mount Hayes Quadrangle, Alaska, in Albert, N.R.D., and Hudson, Travis, eds., The United States Geological Survey in Alaska-
Accomplishments during 1979: U.S. Geological Survey Circular 823-B, p. B64-B66.

Nokleberg, W.J., Aleinikoff, J.N., and Lange, I.M., 1986a, Cretaceous deformation and metamorphism in the northeastern Mount Hayes Quadrangle, eastern Alaska Range, in Bartsch-Winkler, Susan, and Reed, K.M., eds., Geologic studies in Alaska by the U.S. Geological Survey during 1985: U.S. Geological Survey Circular 978, p.64-69.

Nokleberg, W.J., Aleinikoff, J.N., Dutro, J.T., Jr., Lanphere, M.A., Silberling, N.J., Silva, S.R., Smith, T.E., and Turner, D.L., 1992a, Map, tables, and summary of fossil and isotopic age data, Mount Hayes Quadrangle, eastern Alaska Range, Alaska: U.S. Geological Survey Miscellaneous Field Studies Map MF-1996-D, 1 sheet, scale $1: 250,000,43 \mathrm{p}$.

Nokleberg, W.J., Aleinikoff, J.N., Lange, I.M., Silva, S.R., Miyaoka, R.T., Schwab, C.E., and Zehner, R.E., 1992b, Preliminary geologic map of the Mount Hayes Quadrangle, eastern Alaska Range, Alaska: U.S. Geological Survey Open-File Report 92-594, 1 sheet, scale $1: 250,000,39 \mathrm{p}$.

Nokleberg, W.J., Foster, H.L., and Aleinikoff, J.N., 1989, Geology of the northern Copper River basin, eastern Alaska Range, and southern Yukon-Tanana basin, southern and east-central Alaska, in Nokleberg, W.J., and Fisher, M.A., eds., Alaskan Geological and Geophysical Transect: Field Trip Guidebook T104, 28th International Geological Congress, p. 34-63.

Nokleberg, W.J., Jones, D.L., and Silberling, N.J., 1985, Origin and tectonic evolution of the Maclaren and Wrangellia terranes, eastern Alaska Range, Alaska: Geological Society of America Bulletin, v. 96, p. 1,251-1,270.

Nokleberg, W.J., Parfenov, L.M., Monger, J.W.H., Norton, I.O., Khanchuk, A.I., Stone, D.B., Scholl, D.W., and Fujita, K., 2000, Phanerozoic tectonic evolution of the Circum-North Pacific: U.S. Geological Survey Professional Paper 1626, $122 \mathrm{p}$.

Nokleberg, W.J., Schwab, C.E., Miyaoka, R.T., and Buhrmaster, C.L., 1983, Stratigraphy, petrology, and structure of the Pingston terrane, Mount Hayes C-6 and C-5 quadrangles, eastern Alaska Range, Alaska, in Coonrad, W.L., and Elliott, R.L., eds., The United States Geological Survey in Alaska-Accomplishments during 1981: U.S. Geological Survey Circular 868, p. 70-73.

Nokleberg, W.J., Plafker, George, and Wilson, F.H., 1994, Geology of south-central Alaska, in Plafker, George, and Berg, H.C., eds., The Geology of Alaska: Boulder, Colorado, Geological Society of America, The Geology of North America, v. G-1, p. 311-366.

Nokleberg, W.J., Wade, W.M., Lange, I.M., and Plafker, George, 1986b, Summary of geology of the Peninsular terrane, metamorphic complex of Gulkana River, and Wrangellia terrane, north-central and northwestern Gulkana Quadrangle, in Bartsch-Winkler, Susan, and Reed, K.M., eds., Geologic Studies in Alaska by the U.S. 
Geological Survey during 1985: U.S. Geological Survey Circular 978, p. 69-74.

Nokleberg, W.J., Zehner, R.E., and Miyaoka, R.T., 1981c, Geologic setting of the Maclaren metamorphic belt, Mount Hayes A-6 and B-6 quadrangles, eastern Alaska Range, Alaska, in Coonrad, W.L., ed., The United States Geological Survey in Alaska: Accomplishments during 1980: U.S. Geological Survey Circular 844, p. 97-100.

Péwé, T.L., and Holmes, G.W., 1964, Geology of the Mount Hayes D-4 Quadrangle, Alaska: U.S. Geological Survey Miscellaneous Geological Investigations Map I-394, 2 sheets, scale 1:63,360.

Plafker, George, Lull, J.S., Nokleberg, W.J., Pessel, G.H., Wallace, W.K., and Winkler, G.R., 1992, Geologic map of the Valdez A-4, B-3, B-4, C-3, C-4, and D-4 quadrangles, northern Chugach Mountains and southern Copper River basin, Alaska: U.S. Geological Survey Miscellaneous Investigations Series Map I-2164, 1 sheet, scale 1:125,000.

Plafker, George, Nokleberg, W.J., and Lull, J.S., 1989, Bedrock geology and tectonic evolution of the Wrangellia, Peninsular, and Chugach terranes along the Trans-Alaskan Crustal Transect in the northern Chugach Mountains and southern Copper River basin, Alaska: Journal of Geophysical Research, p. 4,255-4,295.

Plafker, George, Moore, J.C., and Berg, H.C., 1994, Geology of the southern Alaska margin, in Plafker, George, and Berg, H.C., eds., The Geology of Alaska: Boulder, Colorado, Geological Society of America, The Geology of North America, v. G-1, p. 389-450.

Reed, B.L., and Lanphere, M.A., 1972, Generalized geologic map of the Alaska-Aleutian Range batholith showing potassium-argon ages of the plutonic rocks: U.S. Geological Survey Miscellaneous Field Studies Map 372, 2 sheets.

Reed, B.L., Miesch, A.T., and Lanphere, M.A., 1983, Plutonic rocks of Jurassic age in the Alaska-Aleutian Range batholith - Chemical variations and polarity: Geological Society of America Bulletin, v. 94, no. 10, p. 1,232-1,240.

Richards, M.A., Jones, D.L., Duncan, R.A., and DePaolo, D.J., 1991, A mantle plume initiation model for the Wrangellia flood basalt and other oceanic plateaus: Science, v. 254, no. 5,029, p. 263-267.

Richter, D.H., 1964, Geology and mineral deposits of the Ahtell Creek area, Slana district, southcentral Alaska: Alaska Division of Mines and Minerals Geologic Report 6, 18 p., 1 sheet, scale 1:31,680.

1966, Geology of the Slana district, southcentral Alaska: Alaska Division of Mines and Minerals Geologic Report 21, 54 p., 3 sheets, scale 1:63,360.

1967, Geology of the upper Slana-Mentasta Pass area, southcentral Alaska: Alaska Division of Mines and Minerals Geologic Report 30, 30 p., 2 sheets, scale 1:63,360. 1976, Geologic map of the Nabesna Quadrangle, Alaska: U.S. Geological Survey Miscellaneous Investigations Series Map I-932, 1 sheet, scale 1:250,000.
Richter, D.H., and Dutro, J.T., Jr., 1975, Revision of the type Mankomen Formation (Pennsylvanian and Permian), Eagle Creek area, eastern Alaska Range, Alaska: U.S. Geological Survey Bulletin 1395-B, p. B1-B25.

Richter, D.H., and Jones, D.L., 1973, Structure and stratigraphy of the eastern Alaska Range, Alaska: American Association of Petroleum Geologists, Arctic Geology, Memoir 19, p. 408-420.

Richter, D.H., Ratte, J.C., Schmoll, H.R., Leeman, W.P., Smith, J.G., and Yehle, L.A., 1989, Geologic map of the Gulkana B-1 Quadrangle, south-central Alaska: U.S. Geological Survey Geologic Quadrangle Map 1655, 1 sheet, scale 1:63,360.

Richter, D.H., Sharp, W.N., Dutro, J.T., Jr., and Hamilton, W.B., 1977, Geologic map of parts of the Mount Hayes A-1 and A-2 quadrangles, Alaska: U.S. Geological Survey Miscellaneous Investigations Series Map I-1031, 1 sheet, scale 1:63,360.

Ridgway, K.D., Trop, J.M., Nokleberg, W.J., Davidson, C.M., and Eastham, K.R., 2002, Mesozoic and Cenozoic tectonics of the eastern and central Alaska Range-Progressive basin development and deformation in a suture zone: Geological Society of America Bulletin, v.114, no. 12, p. 1,480-1,504.

Rohn, Oscar, 1900, A reconnaissance of the Chitina River and the Skolai Mountains, Alaska: U.S. Geological Survey 21st Annual Report, part 2, p. 393-440.

Rose, A.W., 1965, Geology and mineral deposits of the Rainy Creek area, Mount Hayes Quadrangle, Alaska: Alaska Division of Mines and Minerals Geologic Report 14, 51 p. 1966a, Geological and geochemical investigations in the Eureka Creek and Rainy Creek areas, Mount Hayes Quadrangle, Alaska: Alaska Division of Mines and Minerals Geologic Report 20, 41 p., 3 sheets, scale 1:40,000.

1966b, Geology of part of the Amphitheater Mountains, Mount Hayes Quadrangle, Alaska: Alaska Division of Mines and Minerals Geologic Report 19, 17 p.

1967, Geology of the upper Chistochina River area, Mount Hayes Quadrangle, Alaska: Alaska Division of Mines and Minerals Geologic Report 28, 41 p., 2 sheets, scale $1: 40,000$.

Rose, A.W., and Saunders, R.H., 1965, Geology and geochemical investigations near Paxson, northern Copper River basin, Alaska: Alaska Division of Mines and Minerals Geologic Report 13, 38 p.

Schrader, F.C., 1900, A reconnaissance of a part of Prince William Sound and the Copper River district, Alaska, in 1898: U.S. Geological Survey, 20th Annual Report, Part VII, Explorations in Alaska in 1898, p. 341-423.

Sherwood, K.W., and Craddock, Campbell, 1979, General geology of the central Alaska Range between the Nenana River and Mount Deborah: Alaska Division of Geological \& Geophysical Surveys Alaska Open-File Report 116, 24 p., 3 sheets, scale 1:63,360. doi:10.14509/32 
Silberling, N.J., Richter, D.H., and Jones, D.L., 1981, Recognition of the Wrangellia terrane in the Clearwater Mountains and vicinity, south-central Alaska, in Albert, N.R.D., and Hudson, Travis, eds., the U.S. Geological Survey in Alaska-Accomplishments during 1979: U.S. Geological Survey Circular 823-B, p. B51-B55.

Smith, T.E., 1974, Regional geology of the Susitna-Maclaren River area, central Alaska, in Hartman, D.C., ed., Division of Geological \& Geophysical Surveys Annual Report 1973: Alaska Division of Geological \& Geophysical Surveys, Annual Report, 1973, p. 3-6. doi:10.14509/232

1981, Geology of the Clearwater Mountains, southcentral Alaska: Alaska Division of Geological \& Geophysical Surveys Geologic Report 60, 72 p., 3 sheets, scale 1:63,360. doi:10.14509/406

Smith, T.E., and Turner, D.L., 1973, Geochronology of the Maclaren metamorphic belt, south-central Alaska-A progress report: Isochron/West, no. 7, p. 21-25.

Stanley, W.D., Labson, V.F., Csejtey, Béla, Jr., Nokleberg, W.J., Fisher, M.A., and Long, C.I., 1990, The Denali fault system and Alaska Range of Alaska-Evidence for suturing and thin-skinned tectonics from magnetotellurics: Geological Society of America Bulletin, v. 102, p. $160-173$.

Stout, J.H., 1976, Geology of the Eureka Creek area, eastcentral Alaska Range: Alaska Division of Geological \& Geophysical Surveys Geologic Report 46, 32 p., 1 sheet, scale 1:63,360. doi:10.14509/374

Turner, D.L., and Smith, T.E., 1974, Geochronology and generalized geology of the central Alaska Range, Clearwater Mountains, and northern Talkeetna Mountains: Alaska Division of Geological \& Geophysical Surveys Alaska Open-File Report 72, 13 p., 1 sheet, scale 1:250,000. doi:10.14509/167

U.S. Army Corps of Engineers, 1953, Terrain and construction materials, Denali area, Alaska: Department of the Army Engineering Intelligence Study 248, 57 p. plus maps.

1955, Certain aspects of the engineering geology along the Glenn and Richardson highways, Copper River basin, Alaska: Office of the Chief of Engineers, U.S. Army, Engineer Intelligence Study 190, 20 p., 18 plates, scale 1:50,000.
U.S. Army Corps of Engineers, 1959, Terrain study of the Exercise Little Bear area, central Copper River basin, Alaska: Department of the Army Engineering Intelligence Study 258, 73 p., 23 plates, scales 1:50,000 and 1:250,000.

1960a, Terrain study of the Delta River region, Alaska: Department of the Army Engineering Intelligence Study 264, 46 p.

1960b, Terrain study of the Exercise Willow Freeze area, Copper River basin, Alaska: Department of the Army Engineering Intelligence Study 292, 87 p., 21 plates, scales 1:50,000, 1:100,000, and 1:250,000.

U.S. Geological Survey Geologic Names Committee, 2010, Divisions of geologic time-major chronostratigraphic and geochronologic units: U.S. Geological Survey Fact Sheet 2010-3059, 2 p. http://pubs.usgs.gov/ fs/2010/3059/

Wahrhaftig, Clyde, and Hickox, C.A., 1955, Geology and coal deposits, Jarvis Creek coal field, Alaska: U.S. Geological Survey Bulletin 989-G, p. 353-367, 3 sheets.

Wahrhaftig, Clyde, Wolfe, J.A., Leopold, E.B., and Lanphere, M.A., 1969, The coal-bearing group in the Nenana coal field, Alaska: U.S. Geological Survey Bulletin 1274-D, p. D1-D30.

Weber, F.R., 1971, Preliminary engineering geologic maps of the proposed Trans-Alaska Pipeline route, Mount Hayes Quadrangle: U.S. Geological Survey Technical Data Unit Open-File Report 493, 2 sheets, scale 1:125,000.

Williams, J.R., and Galloway, J.P., 1986, Map of western Copper River basin, Alaska, showing lake sediments and shorelines, glacial moraines, and location of stratigraphic sections and radiocarbon-dated samples: U.S. Geological Survey Open-File Report 86-390, 30 p., 1 sheet, scale 1:250,000.

Winkler, G.R., Silberman, M.L., Grantz, Arthur, Miller, R.J., and MacKevett, E.M., Jr., 1981, Geologic map and summary geochronology of the Valdez Quadrangle, southern Alaska: U.S. Geological Survey Open-File Report 80-892-A, 2 sheets, scale 1:250,000. 